\title{
A LATE MIOCENE - EARLY PLIOCENE PARATETHYAN TYPE OSTRACOD FAUNA FROM THE DENIZLI BASIN (SW ANATOLIA) AND ITS PALAEOGEOGRAPHIC IMPLICATIONS
}

\author{
Lea Rausch $^{\mathrm{a}, \mathrm{b}_{*}}$ Marius Stoica $^{\mathrm{a}}$ \& Sergei Lazarev ${ }^{\mathrm{c}}$
}

Received: 25 November 2020 / Accepted: 21 February 2020 / Published online: 22 April 2020

\begin{abstract}
The upper Miocene - lower Pliocene sedimentary succession of the Denizli Basin (SW Anatolia) displays a unique record of undisturbed stratigraphy and provides an excellent opportunity to study long-term palaeoecological changes. This paper documents the ostracod assemblages of two sections of the Neogene Kolankaya Formation, resulting in the following taxonomic, palaeobiogeographic and ecological interpretations. The ostracod assemblages from the two sections consist of a mixture of oligohaline to mesohaline tolerant taxa but expose fundamental differences in their composition. This is reflected by the fact that out of 32 determined species, both sections only have 3 in common. In the stratigraphic older succession, the diverse ostracod fauna resembles taxa known from the Paratethys. Faunal relations to the brackish lake habitats of the Euxinic and Pannonian basins are apparent and the palaeobiogeographic significance of the fauna is discussed. The ostracod association of the younger section indicates a low brackish water habitat with fluctuating salinities, most likely in the oligohaline range. The ostracod assemblage of the Kolankaya Formation only permits a broad age assignment to the late Miocene - early Pliocene.
\end{abstract}

Keywords: Neogene, Ostracods, Palaeoecology, Paratethys, Turkey.

\section{INTRODUCTION}

From the Eocene onwards the Paratethys, a large shallow sea that once covered broad parts of central Eurasia, underwent periodical and continuous sea level fluctuations and subsequently subdivided into several, low salinity basins (e.g. Rögl, 1998; Popov et al., 2006; Krijgsman et al., 2019). These high-amplitude environmental changes encouraged the diversification of faunal assemblages (i.e., ostracods, molluscs, fishes, etc.) that are endemic to the region (e.g., Harzhauser et al., 2002; Wesselingh et al., 2008; Cziczer et al., 2009; Stoica et al., 2013). Lake Pannon, a large long-lived lake occupying the Pannonian Basin (Central Paratethys) during the late Miocene, was the very cradle for the so-called Pontocaspian fauna that originated partly from restricted marine and partly freshwater taxa (e.g., Krstić, 1985; Olteanu, 2011). Species that evolved in the isolated realm of Lake Pannon successfully migrated into the Dacian Basin, Euxinic Basin and Caspian Basin during the early Pontian flooding event (6.1 Ma) (Krijgsman et al., 2010; Stoica et al., 2013, 2016), that re-connected the once separated basins of the Paratethys. This enabled the fauna to survive through the late Miocene, Pliocene, Pleistocene and recent times within ecological analogues of Lake Pannon in nowadays Black Sea region (Razim-Sinoe lake complex, Romania) and the Caspian Sea (e.g., Grigorovich et al., 2003; Yanina, 2012; Krijgsman et al., 2019; Velde and Jorissen, 2019).

Ostracods, bivalved crustaceans that are often mistakenly overlooked due to their diminutive size, provide the means to study the biotic response to past palaeoecological- and palaeogeographic changes (Whatley, 1988). They are perfectly adapted to life in the aquatic realm and are the most abundant calcareous microfossil, occurring in marginal marine and continental aquatic environments (Lister, 1988). They are remarkably sensitive to environmental parameters such as water temperature, salinity and water depth, which is reflected in the shape and configuration of their carapace (e.g., Danielopol et al., 1985; De Deckker and Forester, 1988; Holmes, 1992; Belis et al., 1999). Moreover, they are easily preserved in the sedimentary archives of Pontocaspian basins, allowing the reconstruction of the palaeoenvironment they once dwelt in. A number of studies have used ostracod assemblages to redraw limnological conditions in a large spectrum of lake environments (De Deckker and Forester, 1988; Martens, 1994; Boomer et al., 1996; Horne et al., 2002; De Deckker and Lord, 2017; Alivernini et al., 2018; Rausch and Stoica, 2019).

The Denizli Basin in SW Anatolia (Turkey) (Fig. 1a-b), located in one of the most active extensional regions in the world (e.g., Alçiçek, 2010; Alçiçek et al., 2015) harboured a long-lived lake during the late Neogene (Wesselingh et al., 2008). Long-lived lake environments commonly host ecosystems that are almost or most of the time isolated from the "outside" world often containing endemic ecospecies, tied to specific local biotopes (Martens, 1994; Wesselingh, 2007; Hauffe et al., 2015). For these reasons, long-lived lakes have become model systems in understanding and correlating long-term natural biotic drivers behind the biotic response to perturbations (Martens and Schön, 1999; Belmecheri et al., 2009; Jovanovska et al., 2016). However, it has been difficult testing faunal response in long-lived environments due to the lack of appropriate candidate lakes for these scenarios. One well-studied example is the long-lived lake Ohrid, located in south-eastern Europe (Albania/Macedo-

\footnotetext{
${ }^{\mathrm{a} *}$ University of Bucharest, Faculty of Geology and Geophysics, Balcescu Bd. 1, 010041 Bucharest, Romania, 


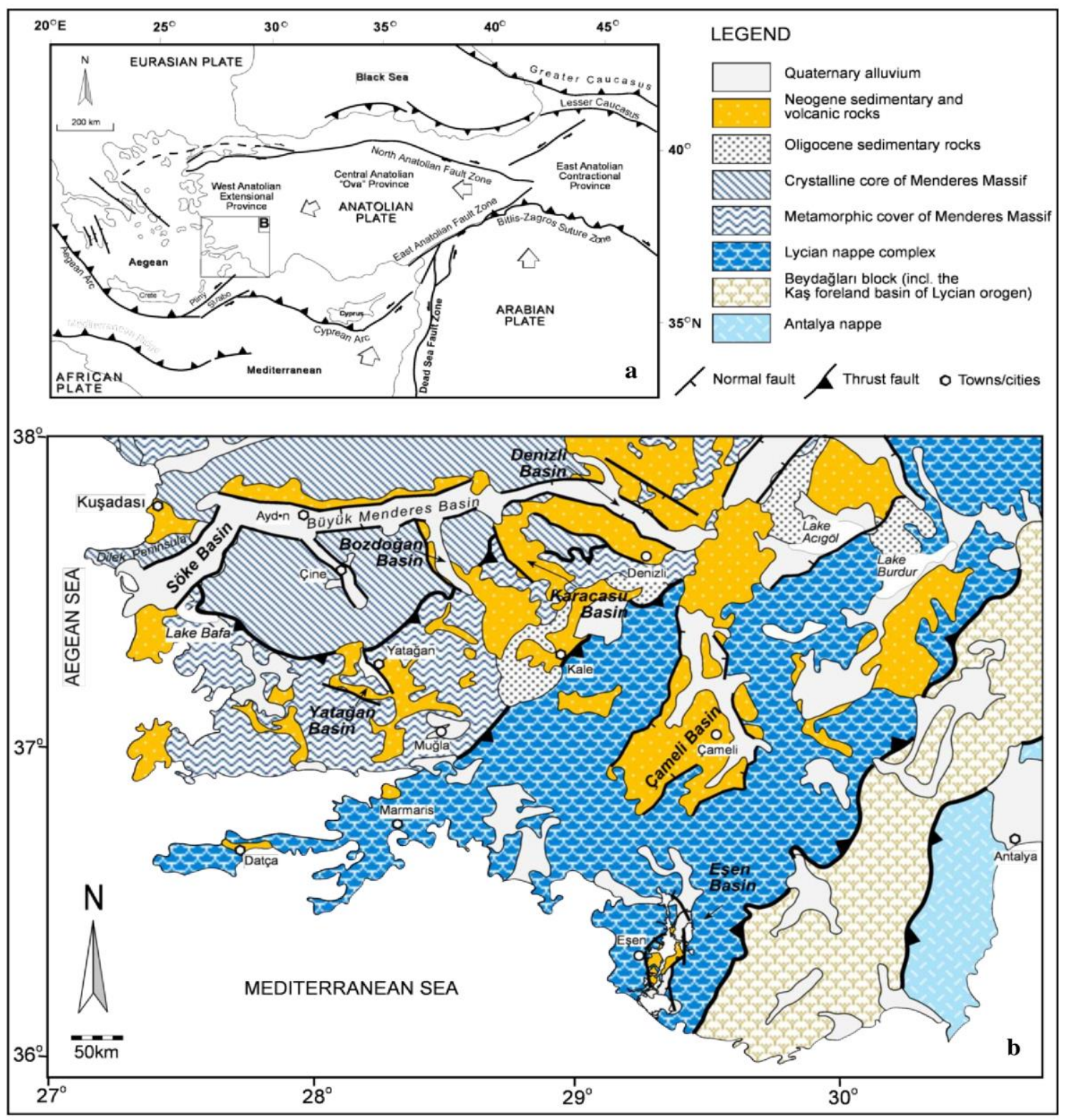

Fig. 1 a Tectonic map of the Aegean Sea and western Turkey showing the main tectonic structures; b Simplified geological map of southwestern Anatolia, Turkey (after Alçiçek, 2010, modified from Bozkurt, 2001 \& Seyitoğlu et al., 2004).

nia). It has been subjected to various studies, including research on the diversity and spatial distribution of ostracod assemblages (Lorenschat et al., 2014) as well as their biogeographic origin. Based on morphological investigations, Namiotko et al. (2012) concluded that ostracods belonging to the family Leptocytheridae are allocated to the genus Amnicythere, indicating that they derived from Lake Pannon species or even pre-existed in Lake Pannon. The authors contemplate that the Leptocytheridae ostracods colonised lakes in Southern Europe stepwise and subsequently adapted to life in freshwater habitats, offering a unique chance of comparative investigations of their evolutionary- and migrational pathways. The hypothesis that faunistic elements, which originated in Lake Pannon and spread through temporary connection during the Miocene and/or Pliocene, is also worth considering when studying the fossil remains inside the sedimentary lake deposits of the Denizli Basin. Previous taxonomic studies on the biota revealed the presence of Paratethyan faunas (molluscs and ostracods), indicating a close biogeographic affinity between SW Anatolia and the Paratethys, mainly Lake Pannon (Freels, 1980; Wesselingh et al., 2008; Şafak, 2010; Sands et al., 2019). The role of Anatolian basins as a source/sink-area of Paratethyan-like ostracod taxa, however remains to be established still.

Here, we present a comprehensive overview of the previously poorly investigated ostracod fauna from the late Miocene - early Pliocene succession of the Denizli Basin. We further discuss the origin and possible link between the geological and biological evolution of the faunal community and investigate the processes driving faunal turnovers by taxonomically describing the encountered assemblages. 


\section{GEOLOGICAL HISTORY OF THE LATE MIOCENE IN THE DENIZLI BASIN}

The Denizli Basin is a WNW-ESE trending extensional depression (Figs. 1, 2) that is approximately $50 \mathrm{~km}$ wide and $70 \mathrm{~km}$ long (Sun, 1990; Alçiçek et al., 2007). It contains a unique stratigraphic record, displaying a complex Miocene to Quaternary basin-fill that is reaching up to $1300 \mathrm{~m}$ in thickness, consisting of alluvial-fan, fluvial and lacustrine deposits (Şimşek, 1984; Alçiçek et al., 2007, 2015; Sun, 1990; Kaymakç1, 2006). The sedimentary succession has developed on a pre-Neogene bedrock, that consists of Paleozoic-Mesozoic metamorphic rocks of the autochthonous Menderes Massif and the Lycian Nappes, which are mainly made of a ophiolitic melange with intercalated allochthonous units that are composed of carbonates of middle Eocene age (e.g., Şimşek, 1984; Bozkurt, 2001; Alçiçek et al., 2015). Neogene deposits are relatively well exposed and have been affected by an ongoing regional extension that started during the late early Miocene (Alçiçek et al., 2007, 2015). The basinfill, referred to as Denizli Group (Sun, 1990), consists of siliciclastic deposits, associated with occasionally occurring carbonates and evaporites (Alçiçek et al., 2007). The sediments unconformably overlie the metamorphic bedrock and are divided into four formations (Şimşek, 1984; Sun, 1990; Alçiçek et al., 2007): the Kızılburun Formation (early - early middle Miocene), the Sazak Formation (middle - early late Miocene), the Kolankaya Formation (late Miocene - late Pliocene), the Tosunlar Formation (early Pleistocene) and alluvial deposits of middle Pleistocene age. The ostracod fauna described herein is obtained from the Kolankaya Formation that can reach up to $500 \mathrm{~m}$ in thickness and is subdivided into four subunits following the classification of Wesselingh et al. (2008; Fig. 3):

(1): a unit that is approximately $100 \mathrm{~m}$ thick and consists of laminated mudstones - siltsone and marls. It is interpreted to represent a shallow water and low energy environment.

(2): a unit $200 \mathrm{~m}$ thick, consisting of alternating marl, clay and sandstones, clayey limestone and black shales. Oxygen isotope measurements indicate the presence of an anomalohaline open lacustrine environment deposited under a gradually shallowing setting (Alçiçek et al., 2007) which is further supported by the presence of a brackish water mollusc fauna of late Miocene age (Nebert, 1958; Taner, 2001; Wesselingh et al., 2008). Based on mammal remains, the unit could be assigned to MN 11-12 biozone (Late Tortonian: Sickenberg and Tobin, 1971; Saraç, 2003).

(3): a unit that consist of thinly bedded and well-sorted, coarse - to very fine-grained sandstones, that additionally shows ripple cross-lamination. The sandstones are overlain by planar crossed-stratified conglomerates and sandstones as well as ripple cross-laminated and massive fine - to coarse grained sandstones. In some layers an abundant mollusc and ostracod fauna, suggesting a Pliocene age and fresh water conditions were found (Nebert, 1958; Taner, 1974a, b, 1975; Freels, 1980; Yalçınlar, 1983). Mammal remains, recovered from the upper part of the unit, suggest the presence of the Late Piacenzian - Early Gelasian biozone MN 17 (Yalçınlar, 1983; Kaymakçı,
2006). The shoreface and foreshore deposits of this unit represent a wave-dominated freshwater lake.

(4): a unit that is approximately $80 \mathrm{~m}$ thick and consists of alternating cross-stratified conglomerates, sandstones and mudstones with few mudstone dominated intercalations. This unit is representing fluvial to alluvial fan deposits.

\section{METHODS}

The ostracod fauna reported herein is obtained from several outcrops, all approximately $5-7 \mathrm{~km}$ northeast of Babadağ village, ca. $15 \mathrm{~km}$ west of Denizli. Due to adverse outcrop conditions (steep slopes) the samples were collected along a composite section formed of several vertical profiles that can laterally be correlated. A well exposed, approximately $85 \mathrm{~m}$ thick succession (section A; Fig. 4a-b; N37 $50^{\prime} 43.70$, E $28^{\circ} 52^{\prime} 54.68$ ) has been logged and sampled for micropalaentology and palaeomagnetism during field campaigns in 2016 and 2018. For micropalaeontological investigations, a total of 21 stratigraphic levels (Fig. 5a) were sampled, in close proximity to the places where palaeomagnetic measurements were taken. The second sampled succession (section B; Fig. 4c; N $37^{\circ} 51^{\prime} 47.15 ; \mathrm{E} 28^{\circ} 53^{\prime} 32.92$ ), stratigraphically located above the previous one, is about $185 \mathrm{~m}$ thick and is exposed on the north-western flank below Babadağ Sarayköy road leading to Babadağ village, approximately $1,9 \mathrm{~km}$ northwest of Acidere village. Micropalaeontological samples and palaeomagnetic measurements were taken from fine grained intervals, yielding a total of 62 samples (Fig. 5b). Between the two mentioned sections two more but minor successions (N 37 $51^{\prime} 6.11^{\prime \prime}$; E

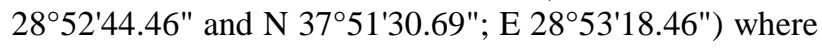
sampled in 2016. Due to a poorly preserved ostracod assemblage, that allowed no appropriate systematic assignment, the samples were not included in this study.

All micropalaeontological samples were recovered from fine grained sediments (clayey siltstones and sandy limestones) and processed using standard micropalaeonontological methods. For a better disaggregation, the samples have been boiled with sodium carbonate before being subsequently washed and sieved over a battery of three sieves $(500-125-63 \mu \mathrm{m})$. The dried residue was handpicked using a ZEISS - GSZ light microscope. The material is housed in the Faculty of Geology and Geophysics, Department of Geology at Bucharest University (Romania). For high resolution figures the ZEISS MERLIN scanning electron microscope (SEM) of the Geological Institute of Romania (Microcosmos Laboratory) was used. For classifying the water salinity we used the following three salinity levels, following the Venezian salinity classification (Symposium on the Classification of Brackish Waters, 1958): fresh water $(0-0,5 \%)$, oligohaline $(0,5-5 \%)$ and mesohaline $(5-18 \%)$.

\section{RESULTS}

The taxonomic investigation revealed the presence of 32 species belonging to a total of 13 genera (Fig. 5a, b). The ostracods are well preserved and highly abundant but moderate in species numbers. The quantitative analysis of the ostracod association, integrated with data derived 


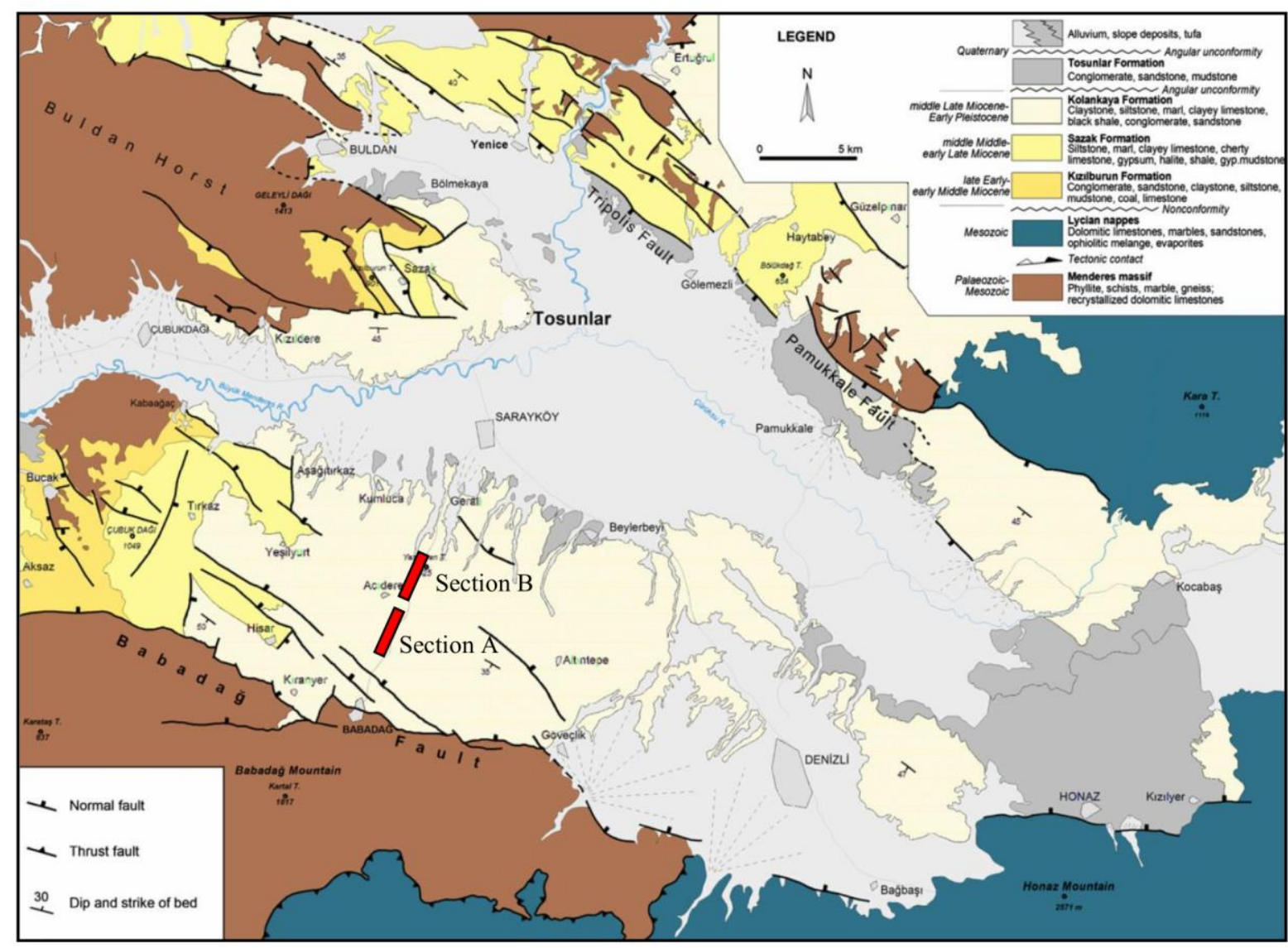

Fig. 2 Geological map of Denizli Basin with the location of investigated sections (A and B) (from Alçiçek et al., 2015, modified from Sun, 1990 and adapted from Konak and Şenel, 2002)

from palaeomagnetic measurements, is indicating a late Miocene - early Pliocene age, confirming the previously mollusc based age assumption. The palaeomagnetic record shows the presence of a reversed chron for the stratigraphically older succession (section A), followed by a long normal cron for the overlying section (section $\mathrm{B}$ ). The preliminary correlation is to $\mathrm{C} 3 \mathrm{r}-\mathrm{C} 3 \mathrm{n}$. 4n (Thvera subcron) which ranges between $6.033-4.997 \mathrm{Ma}$. The faunal assemblage in section A (Fig. 5a) is dominated by leptocytherid ostracods including common occurrences of Leptocythere sp. 1, Amnicythere multituberculata, Amnicythere striatocostata, Amnicythere sp. 3, Amnicythere sp. 4 and loxoconchid species (Loxoconcha babazananica, Loxoconchissa (Loxocaspia) aff. reticulata) as well as some rare occurrences of Cyprideis pannonica, Amnicythere sp. 1 and Tyrrhenocythere aff. pontica. Candonid ostracods are represented by common occurrences of Caspiocypris carica, Candona (Typhlocyprella) sp. together with Typhlocypris fossulata fossulata n. ssp. and Typhlocypris fossulata reticulata $\mathrm{n}$. ssp. We could only observe minor shifts in the faunal composition, indicating the presence of a stable, brackish (oligohaline to lower mesohaline) water environment. The presence of both adults and different juvenile stages, prove the in situ character of the fauna, excluding the presence of reworking processes.

Within section B (Fig. 5b) slight changes in the faunal composition could be observed. The ostracod community is dominated by candonids (Candona angulata, Candona ex. gr. angulata) and loxoconchids (Loxoconcha muelleri, Loxoconcha eichwaldi) suggesting oligohaline mesohaline conditions. In some levels the occurrence of heavy calcified ostracod valves, accompanied with a minor diversification of the assemblage, is indicating a slight increase in alkalinity. These levels contain taxa like Amnicythere sp. 2, Cyprideis torosa, Tyrrhenocythere pontica, Tyrrhenocythere sp., Tyrrhenocythere aff. ruggierii, Loxoconcha petasa and L. muelleri. Besides the dominance of $C$. angulata and $L$. eichwaldi few levels with an increasing presence of nodded Cyprideis torosa as well as L. petasa and L. muelleri could be seen. Rare cases of monospecific occurrences of $L$. muelleridominated assemblages suggest restrictive periods. Within the uppermost parts of the succession the valves show thicker and more ornate valves and L. petasa ssp. $1, L$. petasa ssp.2, Euxinocythere (Maeotocythere) bosqueti, Amnicythere sp. 1, A. sp.2 and C. torosa are commonly occurring. Along the succession rare occurrences of Cypria sp., Candona sp. as well as Ilyocypris bradyi and Ilyocypris gibba suggest the minor influence of a neighbouring freshwater environment.

\section{SYSTEMATIC PALAEONTOLOGY}

The taxonomic concept is based on previously published work by Moore (1961), Van Morkhoven (1962) and Hartmann (1966). Furthermore information on the taxonomy provided in the work of Livental (1929), Agalarova et al. (1961), Agalarova (1967), Yassini (1986), Jiř́iček (1985), Krstić $(1973 ; 1985 ; 1989)$ and Olteanu (1995) 


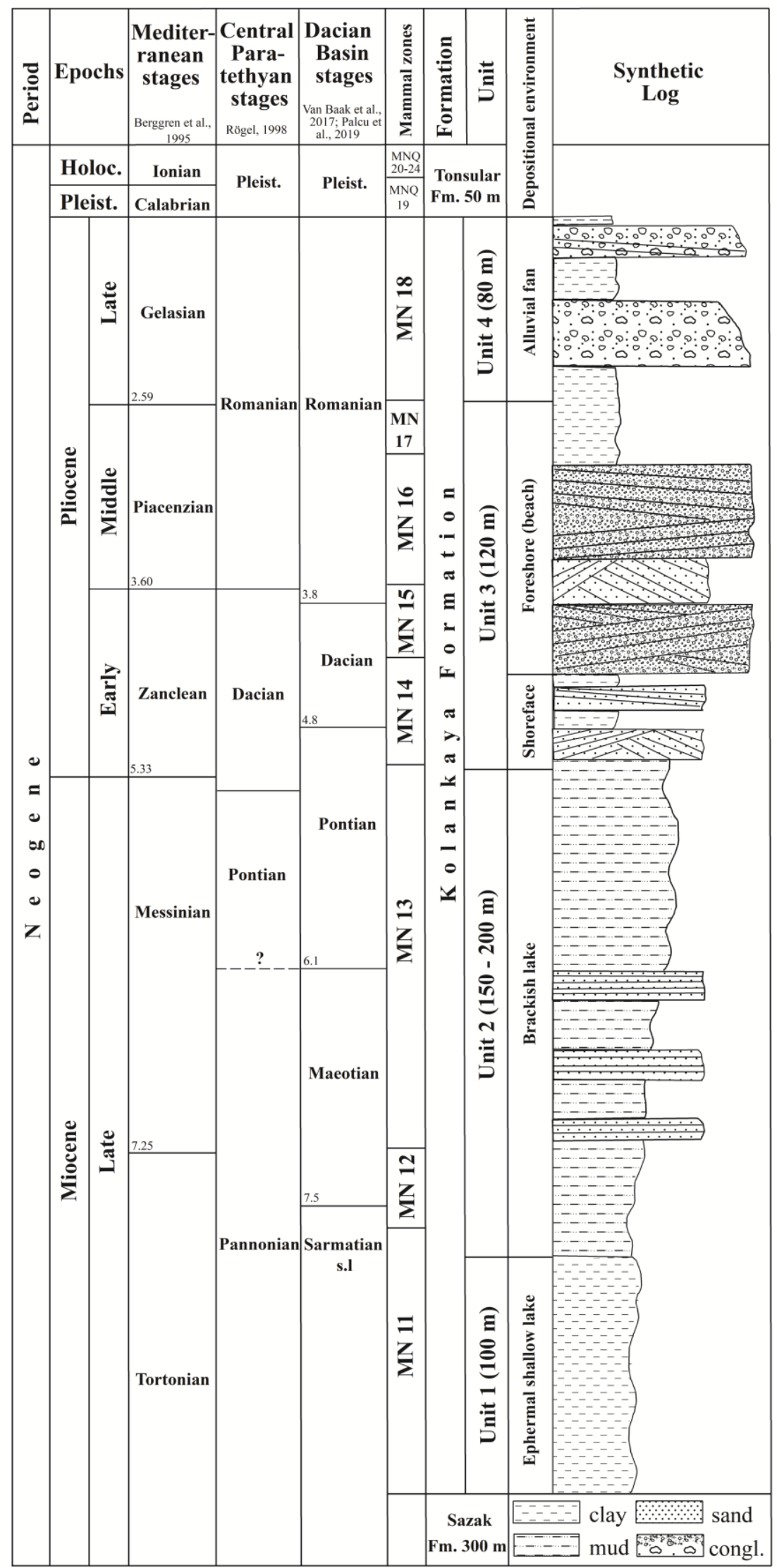

Fig. 3 Stratigraphic framework of the Denizli Basin and the lithology of the Kolankaya Formation (modified after Wesselingh et al., 2008). 

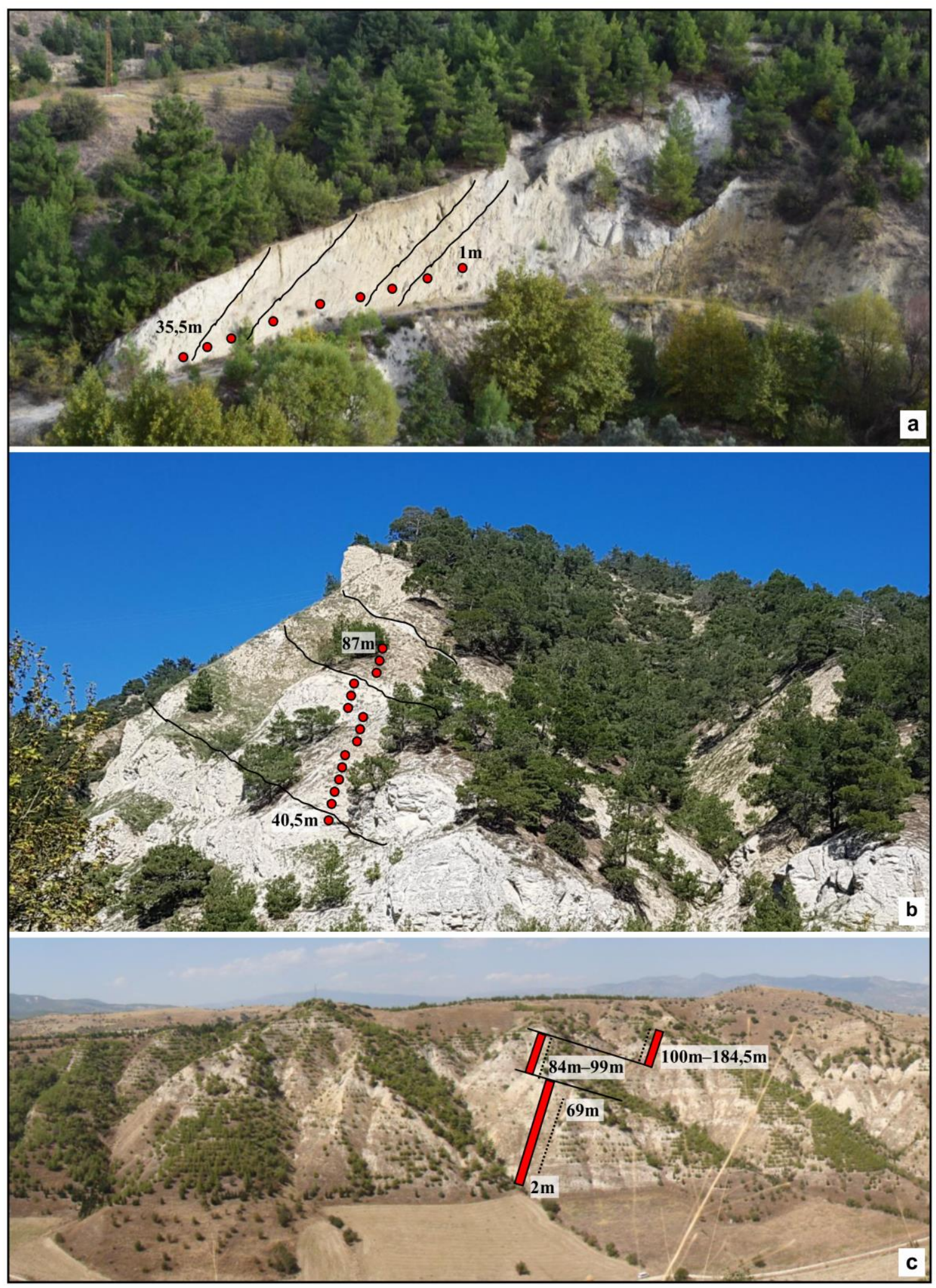

Fig. 4a-c Overview of composite sections formed by several vertical profiles that can be laterally correlated. a-b Overview picture of successions that compose Section A (N37 $50^{\prime} 43.70$, E $\left.28^{\circ} 52^{\prime} 54.68\right)$; a first $35 \mathrm{~m}$ and b remaining $50 \mathrm{~m}$ that are correlated on top and located opposite of the road; c Overview of the Section B and approximate locations of sampled profiles (N 3751’47.15; E2853’32.92). 


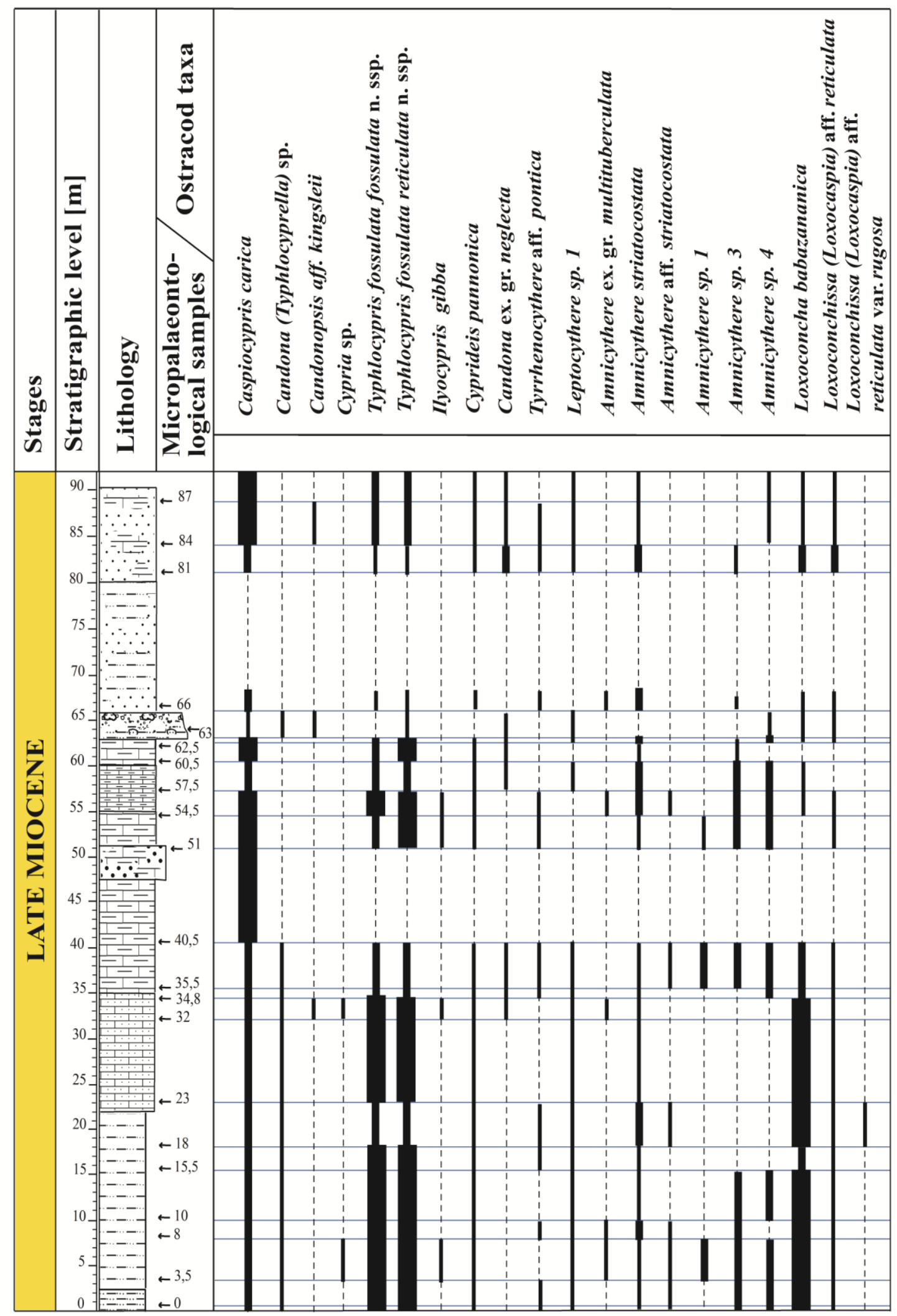

Fig. 5a Ostracod distribution charts for Section A and Section B. 


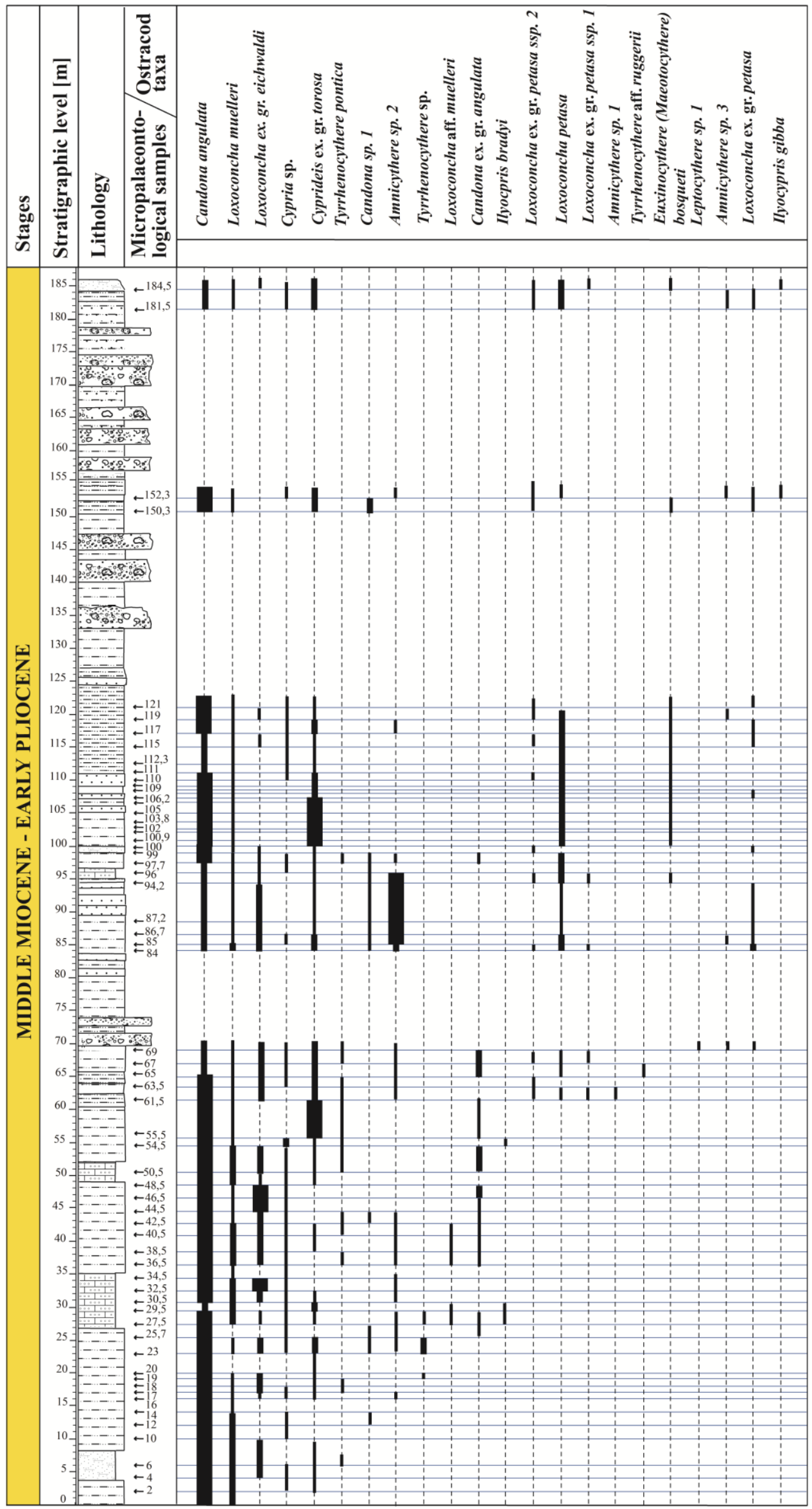

Fig. 5b Ostracod distribution charts for Section A and Section B. 
was taken into account. For the suprageneric classification we followed Meisch (2000) and Horne et al. (2002). Abbreviations: $\mathrm{LV}=$ left valve; $\mathrm{RV}=$ right valve, $\mathrm{C}=$ carapace; $q=$ female; $\hat{\delta}=$ male

Phyllum Arthropoda Siebold \& Stannius, 1845

Class Ostracoda Latreille, 1806

Subclass Podocopa Sars, 1866

Order Podocopida Sars, 1866

Suborder Cypridocopina Jones, 1901

Superfamily Cypridoidea Baird, 1845

Family Candonidae Kaufmann, 1900

Genus Caspiocypris Mandelstam, 1960

Caspiocypris carica (Freels, 1980)

Fig. 6a-h

1980 Candona (Caspiocypris) carica n. sp. -Freels, p.145, pl. 156, fig. $14-16$.

Description. The carapace has a trapezoidal to elongated shape in lateral view. The dorsal margin is almost straight, slightly convex and sloping towards the anterior end that is broadly rounded and continues smoothly onto the ventral margin. The posterior end is pointed and the LV shows a "rostrum-like" end a bit above the joint with the ventral boarder. The ventral margin displays a clear concavity mid-length that is more accentuated in the RV. The postero-ventral joint is slightly pointed upwards on the LV. The valves surface is smooth. The inner lamella is broadly developed in both the anterior-and the posterior end. Marginal pore canals are straight. Dimension: $\mathrm{L}=$ $0,91-1,28 \mathrm{~mm}, \mathrm{H}=0,44-0,67 \mathrm{~mm}$, the minimum sizes include juveniles too.

Remarks. The observed species differentiates from Caspiocypris vaga Stancheva (1964), mentioned from the upper Maeotian deposits from Bulgaria, which is smaller in size and lacks the pointed posterior end. The ventral concavity in $C$. vaga Stancheva is located behind the mid-length of the valve. Also, the dorsal margin of $C$. vaga in the $\mathrm{LV}$ shows a slight median concavity that is not clearly sloping towards the anterior like in our species. Quite similar forms are described under the name Candona slamkovae, by Pipík and Bodegard (2007) from the Pannonian of the Turiec Basin in Slovakia, but differences concerning the outline, especially of the LV are present. Candonids of "trapezoid" shape are often recorded in sediments from Lake Pannon (e.g., Krstić, 1989; Pipík and Bodegard, 2007) as well as from the Maeotian of the Dacian Basin (Stancheva, 1990; Olteanu, 1989, 1995).

Chronostratigraphical and geographical distribution. The type locality of the species is a sedimentary succession $15 \mathrm{~km}$ NE of Denizli (Turkey) within Irlaganlı Valley. The species is possibly ranging from the late Miocene to Pliocene (Freels, 1980). The species commonly occurs in section A.

Ecology. Recent living representatives of the genus and subgenus inhabit a wide range of aquatic habitats, ranging from littoral and profundal zones of lakes or swamps to slightly salty inland and coastal waters (Meisch, 2000).
Candona angulata (Müller, 1900)

Fig. 7a-1

1900 Candona angulata n. sp. Müller, p. 18, pl. I, fig. 117.

1990 Candona angulata Müller - Fuhrmann \& Pietrzeniuk, p. 209, pl. 4, fig. 6-9.

2000 Candona angulata Müller- Meisch, p. 87, fig. 31A-E.

2005 Candona angulata Müller- Viehberg, p. 65, fig. 6, 13.

2008 Candona angulata Müller- Fuhrmann, pl. 2, Fig. 6a-d.

2012 Candona angulata Müller- Fuhrmann, p. 24, pl. 6, fig. 1a-f, 2a-d.

Description. The carapace, usually distinctly elongated, has a similar shape to that of $C$. neglecta in lateral view. Only the posterior expansion of the LV is slightly more pointed and expanded, varying from a rounded to a toothshaped curvature. The RV in contrast lacks this expansion and sculpts only a weak ankle to the concave ventral margin. The LV overlaps the RV at both ends. The valves surface is smooth. The inner lamella is well developed and slightly broader in the anterior. It continues along the ventral margin and numerous, close-set and curved pore canals are present. The muscle scar forms a row of three scars with a larger elongated one above. The male carapace is larger and higher than that of the compressed female and has a more pronounced ventral concavity. Dimension: $\mathrm{L}=0,86-1,72 \mathrm{~mm}, \mathrm{H}=0,27-1,01 \mathrm{~mm}$, the minimum sizes include juveniles too.

Chronostratigraphical and geographical distribution. The species is well known from coastal regions of Ireland, UK, Belgium, Netherlands, Poland, Russia (Volga Basin) and North Africa (Meisch, 2000). It has been described from the southern Balkans (Lake Dojran; Petkovski, 1958) as C. angulata meridionalis and northern Africa, where populations described by Gauthier (1928), according to Meisch (2000) should also belong to the same species. It has further been reported from Pleistocene deposits from Central and Northern Germany (Fuhrmann, 2012; Viehberg, 2005). Within Section B, C. angulata is the most common occurring species.

Ecology. Living representatives of this halo-tolerant species prefer slightly salty water and have often been observed in brackish coastal ponds, ditches and river mouths with salinities ranging from 0,2 - 14\%o (Meisch, 2000).

\section{Candona ex. gr. angulata (Müller, 1900)}

Fig. 8a-p

Description. This species has a similar outline as $C$. angulata but displays no distinctive pointed posterior end on the LV. C. ex. gr. angulata further appears slightly more elongated with a weaker pronounced concavity of the ventral margin. Dimension: $\mathrm{L}=0,46-1,51 \mathrm{~mm}, \mathrm{H}=$ $0,23-0,82 \mathrm{~mm}$, the minimum sizes include juveniles too. 


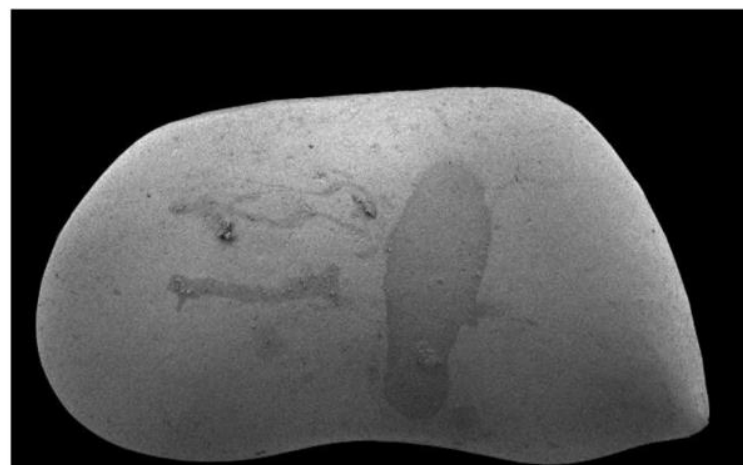

$\mathbf{a}$

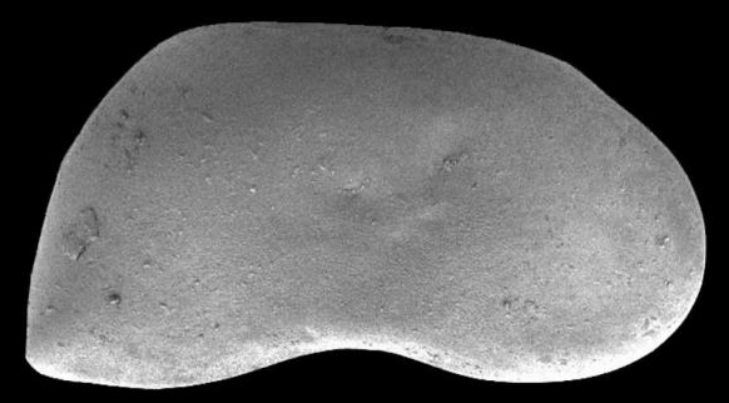

b
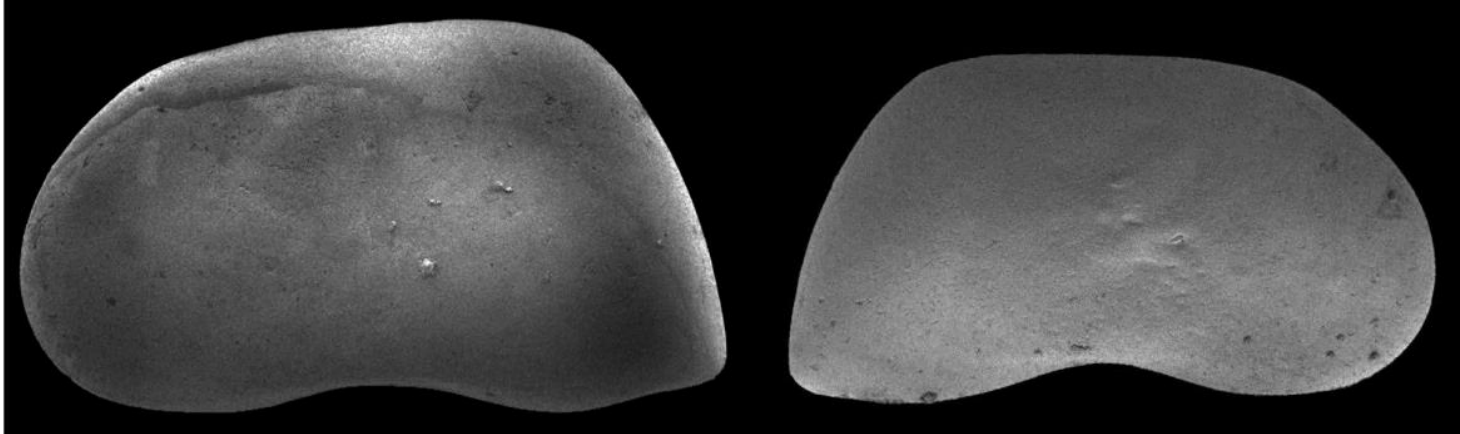

c
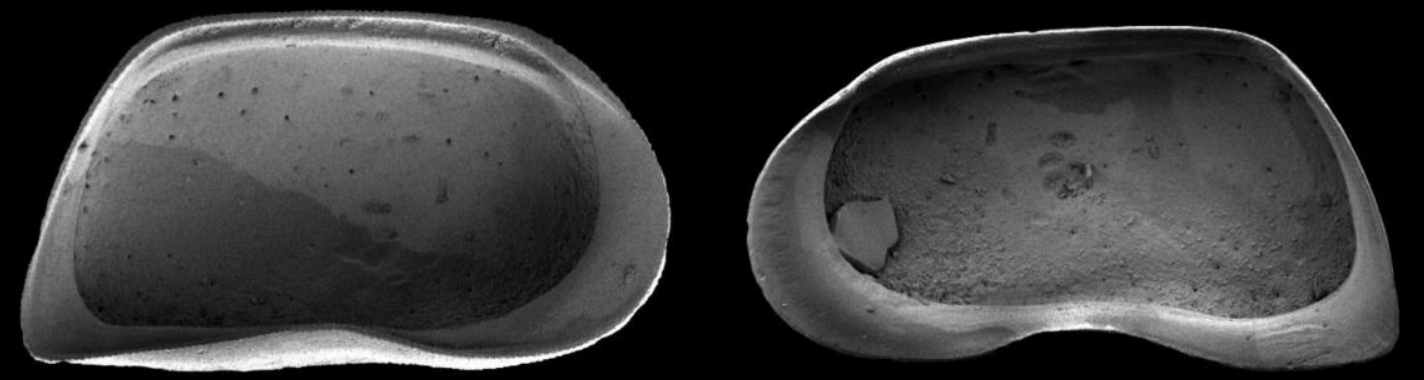

$\mathbf{e}$

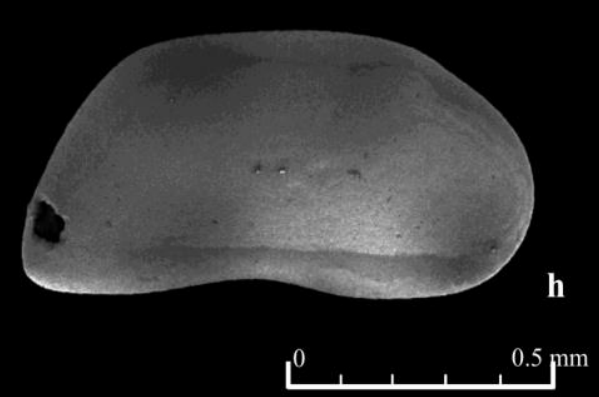

Fig. 6a-h Caspiocypris carica; a, c LV, external view; b, d RV, external view; e LV, internal view; f RV, internal view; $\mathbf{g}$ LV, external view, A1 juvenile; h RV, external view, A1 juvenile; (all specimens from section A, samples $0 \mathrm{~m}$ $-35,5 \mathrm{~m})$. 


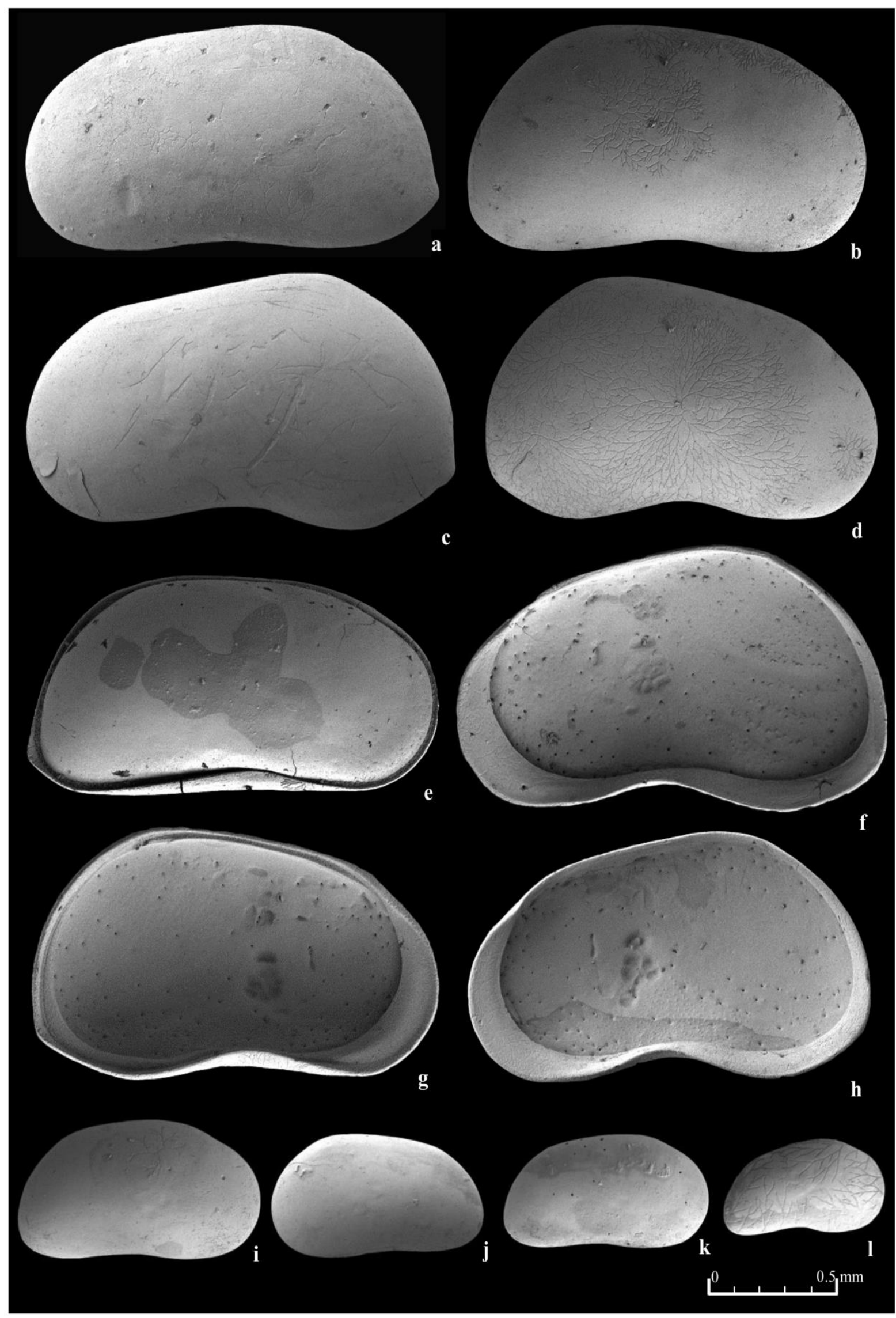

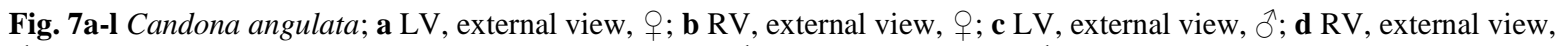

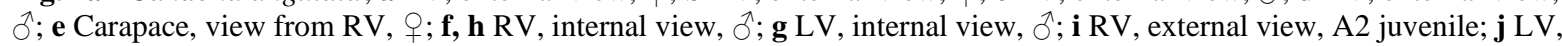
external view, A3 juvenile; k RV, external view, A3 juvenile; 1 RV, external view, A4 juvenile; (all specimens from section $\mathrm{B}$, sample $10 \mathrm{~m}$ ). 


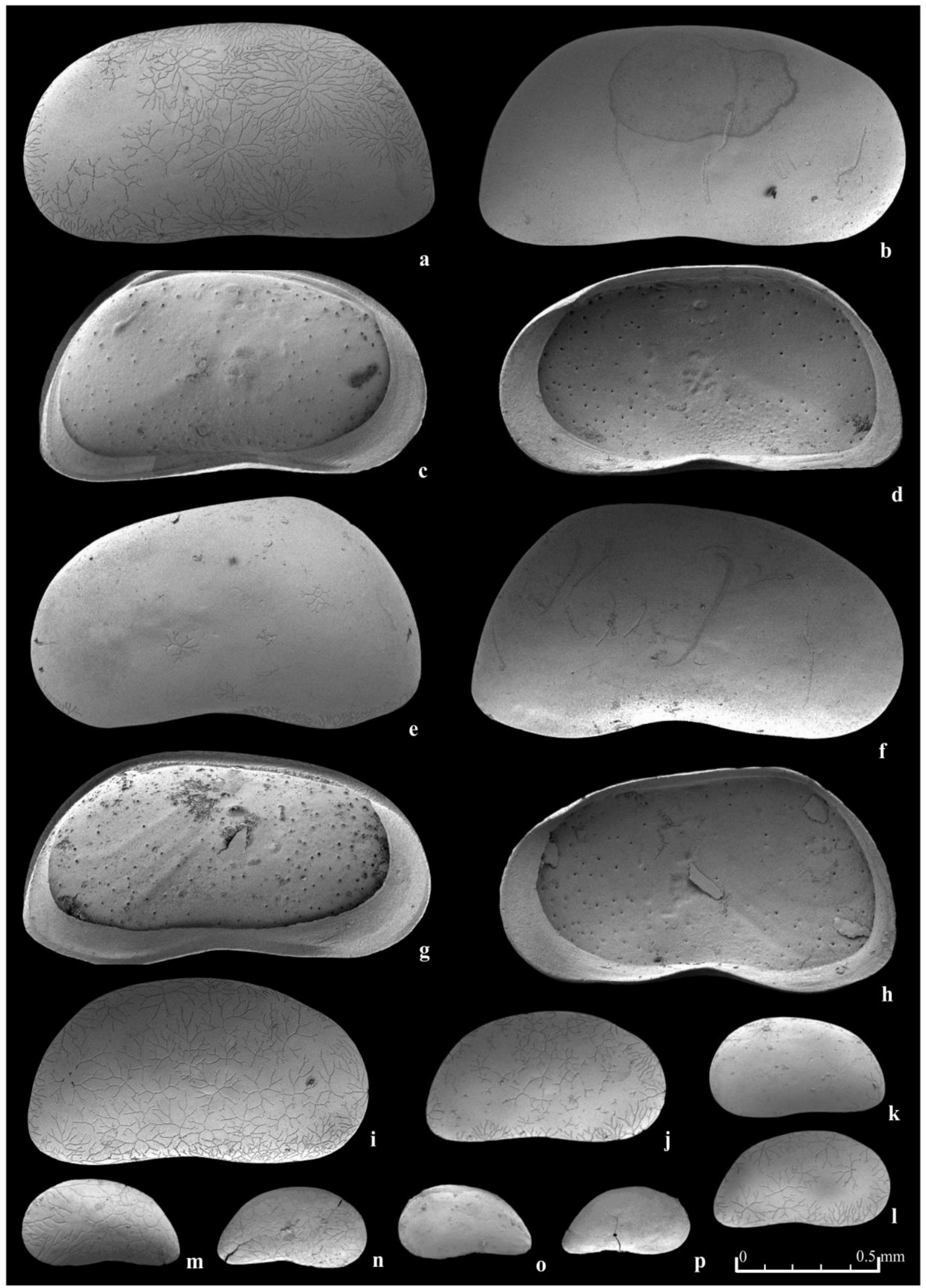

Fig. 8a-p Candona ex. gr. angulata; a LV, external view, $९$; b RV, external view, + ; c LV, internal view, + ; d RV, internal

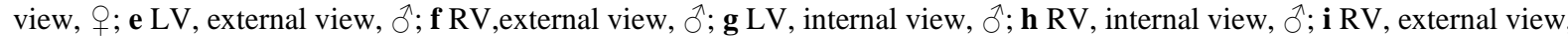
A1 juvenile; j RV, external view, A2 juvenile; k LV, external view, A3 juvenile; I RV, external view, A3 juvenile; m LV, external view, A4 juvenile; $\mathbf{n}$ RV, external view, A4 juvenile. o LV, external view, A5 juvenile; $\mathbf{p}$ RV, external view, A5 juvenile; (all specimens from section B, sample 97,7 m). 
Candona ex. gr. neglecta (Sars, 1887)

Fig. 9f-g

1887 Candona neglecta n. sp. - Sars, p. 279, pl. 15, fig. 5-7, pl. 19.

1969 Candona neglecta Sars partim - Diebel \& Pietrzeniuk, p.473, pl. 7, fig. 6-8.

1980 Candona neglecta Sars- Freels, p. 94, pl. 16, fig. 12-19.

2000 Candona neglecta Sars- Meisch, p. 77, fig. 26A-C, 27A-B.

2001 Candona neglecta Sars- Tunoğlu \& Ünal, p. 176, pl. 3 , fi g. 1.

2005 Candona neglecta Sars- Matzke-Karasz \& Witt, p. 120 , pl. 1, fig. 6-7.

2008 Candona neglecta Sars- Fuhrmann, pl.2, fig. 2a-d.

2012 Candona neglecta Sars- Fuhrmann, p. 32, pl. 10, fig. 1a-f, 2a-d.

2018 Candona ex. gr. neglecta- Jorissen et al., p. 14, fig. 11 (8-9).

Description. The highly variable but usually elongated carapace shows an almost straight dorsal margin that is sloping towards the anterior. The ventral margin is slightly concave. Both the posterior-and the anterior margin are broadly rounded. From the dorsal view, the anterior end is slightly pointed rather than the posterior. The LV overlaps the RV at both ends. This species shows a fine pitted ornamentation pattern in the central area of the valve, leaving out the posterior-and anterior end. Dimension: $\mathrm{L}$ $=0,75-0,92 \mathrm{~mm}, \mathrm{H}=0,37-0,47 \mathrm{~mm}$, the minimum sizes include juveniles too.

Remarks. The species is only rarely observed in our material and mainly appears in juvenile stages. The general outline resembles the one of $C$. neglecta, but the valves surface is showcasing some minor ornamentation represented by small pits. We assign the present species to be part of the Candona neglecta group with some uncertainties.

Chronostratigraphical and geographical distribution. The species has a wide stratigraphic range and has been reported from Serravallian to Recent (Medici et al., 2011). It is further known from the early Pannonian and Pontian of the Gelibolu Peninsula (NW Turkey; Tunoğlu and Ünal, 2001) as well as from Pleistocene deposits of the Burdur Basin (Suludereköy and Kuruçayköy Fm.) in SW Anatolia (Freels, 1980). Other occurrences include Pliocene - early Pleistocene deposits from Central Italy (Valle Orsa Fm.; Spadi et al., 2018) and deposits from the Slănicul de Buzău section (Dacian - Romanian stage) in the Dacian Basin (Van Baak et al., 2015; Jorissen et al., 2018), upper Miocene freshwater strata from Turiec Basin (Slovakia; Pipík and Bodergat, 2007) and the upper Pontian of the Dacian Basin (Ter Borgh et al., 2014).

Ecology. C neglecta occurs in a wide range of aquatic habitats and prefers slightly cold water but can also tolerate temporary increase in temperature beyond $20^{\circ} \mathrm{C}$. It has been reported from coastal-and inland waters with a salinity range of 0,5 - 16\% (Meisch, 2000). In lakes it has been observed from the shallow littoral zone down to depths of $311 \mathrm{~m}$ (Lago Maggiore, Italy; Meisch, 2000). Together with C. ex. gr. torosa and I. gibba (Ramdohr) it has been described as freshwater assemblages from the
Romanian stage of the Slanicul de Bazau section in the Dacian Basin (Van Baak et al., 2015).

\section{Candona sp. 1}

Fig. 9a-e

Description. The carapace has an elongated to subreniform shape in lateral view with the dorsal-and ventral margins running almost parallel. Both, the anterior-and the posterior end are broadly rounded in an almost symmetrical way. The ventral margin has a slight concavity in the median area. The inner lamella is narrow in both the anterior-and the posterior end, suggesting the presence of A1 juvenile stages, despite of the large size. Dimension: $\mathrm{L}=0,56-1,00 \mathrm{~mm}, \mathrm{H}=0,29-0,48 \mathrm{~mm}$, the minimum sizes include juveniles too.

\section{Genus Candonopsis Vávra, 1891}

Candonopsis aff. kingsleii (Brady \& Robertson, 1870) Fig. 9h-k

1870 Candona kingsleii nov. sp - Brady \& Robertson, p. 17, pl. IX, figs. 9-12.

1980 Candonopsis kingsleii (Brady \& Robertson, 1870) - Kempf and Scharf, p. 212, pl. 4, fig. 1-5, pl. 5, fig. 1-3.

1985 Candonopsis kingsleii (Brady \& Robertson)Krstić, pl. 4, figs. 1,2.

2000 Candonopsis kingsleii (Brady \& Robertson, 1870)- Meisch, p.209, fig. 89 A-D.

2012 Candonopsis kingsleii (Brady \& Robertson, 1870)- Fuhrmann, p. 102, Pl. 45, 1a-1e

Description. The carapace has a sub-reniform shape in lateral view and has its greatest width slightly behind mid-length. The dorsal margin is arch-shaped whereas the ventral margin shows a more or less pronounced concavity. Both anterior-and posterior are broadly rounded. Dimension: $\mathrm{L}=0,46-0,93 \mathrm{~mm}, \mathrm{H}=0,26-0,51 \mathrm{~mm}$, the minimum sizes include juveniles too.

Chronostratigraphical and geographical distribution. The species is known from Pannonian strata of Serbia, appearing in the Hemicytheria tenuistriata zone (Krstić, 1985).

Ecology. Representatives of this genus prefer littoral lakes, small permanent-and temporary waters with a maximum salinity of $5 \%$ (oligohaline; Meisch, 2000).

Family Cyclocyprididae Kaufmann, 1900

Genus Cypria Zenker, 1854

\section{Cypria sp.}

Fig. 10a-j

Description. The carapace has the typical triangular to subovate shape and shows the greatest height slightly behind mid-length. The dorsal margin is convex and passes smoothly onto both the anterior-and the posterior end. The dorso-posterior segment is being somewhat more inclined, especially on the RV. The ventral margin of the LV is almost straight, whereas the RV shows a weak concavity. The valves surface is smooth. The inner lamella is moderately pronounced, with the anterior ves- 


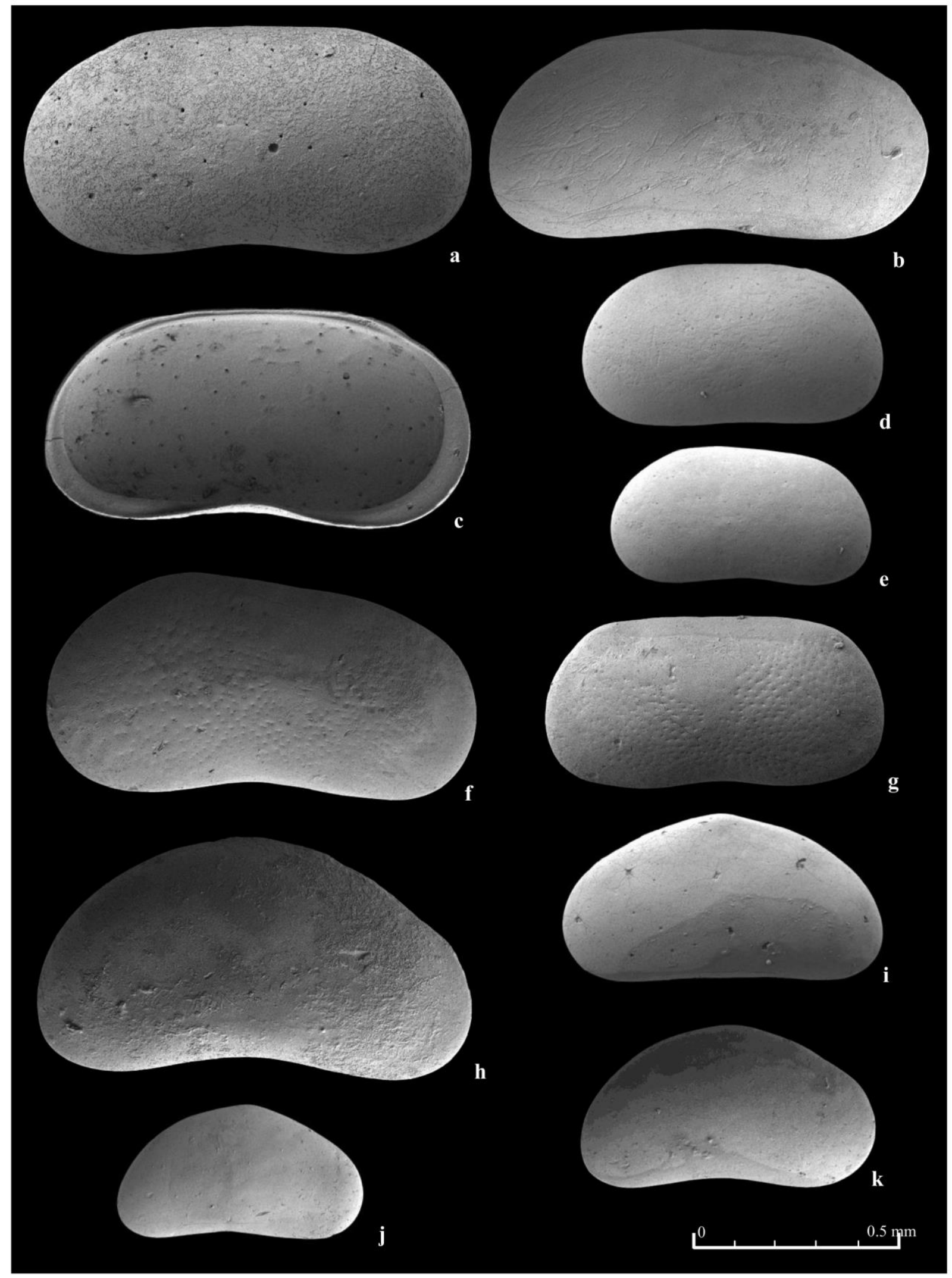

Fig. 9a-e Candona sp.1; a LV, external view; b RV, external view; c LV, internal view; d LV, external view, A1 juvenile; LV, external view, A2 juvenile; f, g Candona ex. gr. neglecta; f RV, external view; g LV, external view, A1 juvenile; h-k Candonopsis aff. kingsleii.; h RV, external view; i LV, external view, A1 juvenile; j RV, external view, A2 juvenile; k RV, external view, A1 juvenile; (specimens from a-e from section B, sample $23 \mathrm{~m}$; a-g from section B, sample 8 m; h-k from section B, sample $9 \mathrm{~m}$ ). 

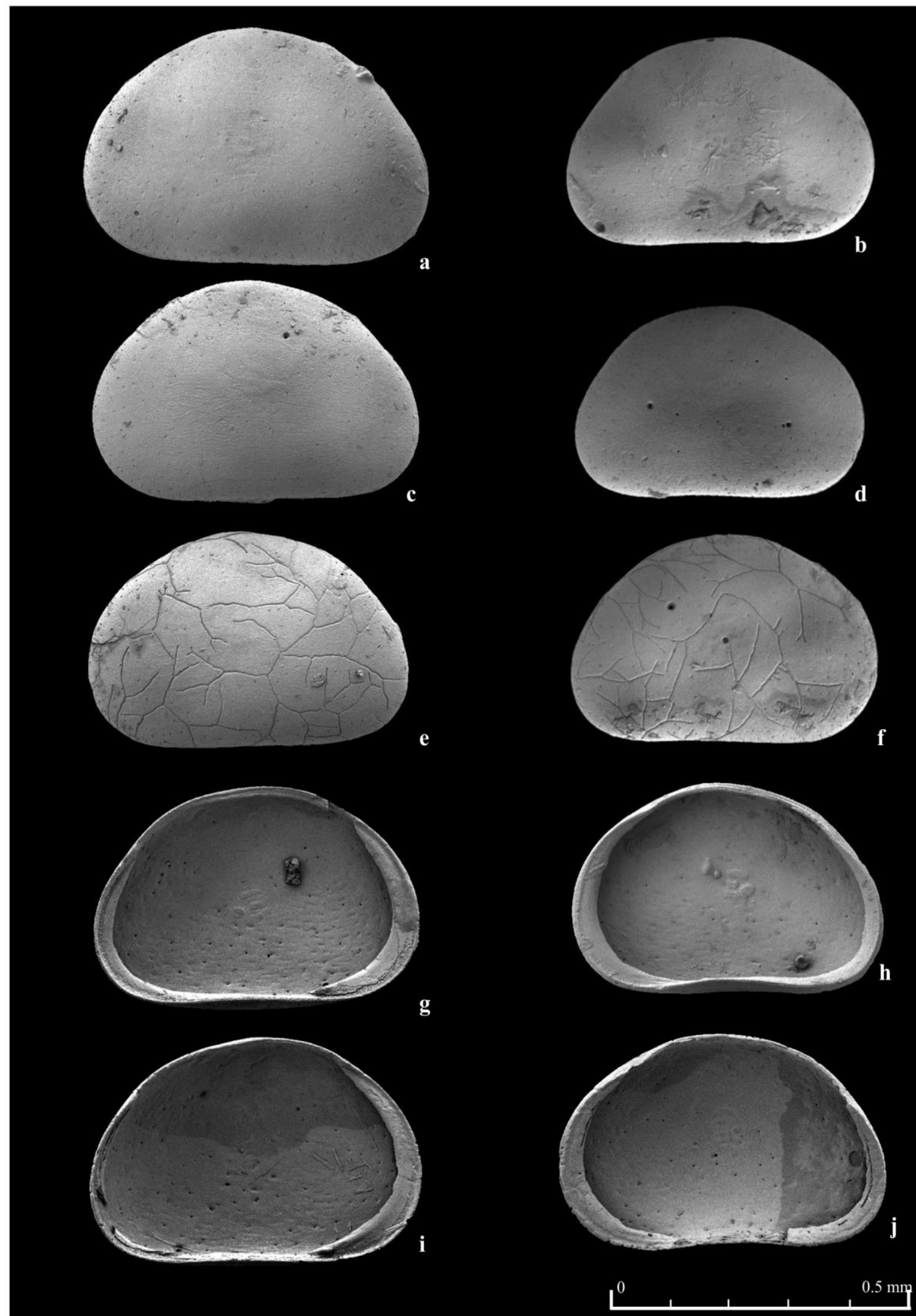

Fig. 10a-j Cypria sp.; a, c, e LV, external view; b, d, f RV, external view; g, i LV, internal view; h, j RV, internal view; (specimens a-d and $\mathrm{g}$-j from section A, samples $0 \mathrm{~m}-35,5 \mathrm{~m}$; specimens e-f from section $\mathrm{B}$, sample $10 \mathrm{~m}$ ). 
tibulum being slightly wider than the posterior one. The hinge is adont and the central muscle scar forms a group of four larger scars and another set of two smaller scars that are located slightly below. From the internal view the LV possess a small elongated knob at the antero-ventral end of the marginal area that corresponds to an elongate depression on the RV. Dimension: $\mathrm{L}=0,51-0,58 \mathrm{~mm}$, $\mathrm{H}=0,33-0,39 \mathrm{~mm}$, the minimum sizes include juveniles too.

Remarks. The genus is a minor faunal element in the observed samples. Similar species have been described under the name Cypria tesle and Cypria pannonica by Krstić (1985) from Pannonian sediments of Serbia. The poor quality of the images of those two species from Krstić (1985) however did not allow a precise determination of the present species to either one of them.

Ecology. The genus Cypria comprise, according to Meisch (2000), approximately 35 recent species with an almost worldwide distribution, inhabiting environments with oligohaline to freshwater conditions.

Candona (Typhlocyprella) sp. (Krstić, 1972) Fig. 11a-k

Description. This species is distinguished by its elongated subtrapezoidal shape and a sharp pointed posterior end. The dorsal margin is straight and angularly connected to the anterior-and posterior end. The anterodorsal margin shows a slight concavity, more visible on the RV. The ventral boarder is much longer than the dorsal one, running almost straight on the LV and with a slight but widespread concavity on RV. The LV is much higher and visibly overlaps the RV. The valves surface is smooth and thin. The inner lamella is well developed in both anterior and posterior, less so ventrally. The tooth plate is adont, the dorsal margin of the RV is fitting into the straight groove of LV. Juveniles in general show a more arcuate dorsal margin and are more pointed posteriorly. Dimension: $\mathrm{L}=0,74-1,22 \mathrm{~mm}, \mathrm{H}=0,35-0,61 \mathrm{~mm}$, the minimum sizes include juveniles too.

Remarks. This uniquely shaped species can be assigned to Typhlocyprella a subgenus of Candona described by Krstić, (1972). This species differs from other species known from the Pannonian including Candona (Typhlocyprella) applanata Pokorný, 1952, Candona (Typhlocyprella) lineocypriformis Krstić, 1972, Candona (Typhlocyprella) elongata Sokać, 1972 and Candona (Typhlocyprella) ankae, Krstić, 1972. Its prominent subtrapezoidal shape, sharp posterior end and the lack of any pointed anterodorsal extension on $\mathrm{LV}$, as in the case of $C$. (T.) lineocypriformis, excludes assigning the species accordingly.

Chronostratigraphical and geographical distribution. The species is only poorly preserved and most of the specimens are broken due to their thin, fragile shells. Other species of this genus are known from the Pannonian of the Vienna Basin, Austria and Yugoslavia (Krstić, 1972; Sokač, 1972).

Family Eucandonidae Swain, 1961

Genus Typhlocypris Vejdovský, 1882

Typhlocypris fossulata (Pokorný, 1952)

1952 Candona fossulata n. sp.- Pokorný, p. 264, pl. 2, fig. 3 .
1972 Candona (Typhlocypris) fossulata (Pokorný)- Sokač, p. 59-60, pl. 18, fig.1.

1980 Candona (Typhlocypris?) ex. gr. fossulata Pokorný- Freels, p. 63, pl. 9, fig. 21-26.

1985 Typholocypris fossulata (Pokorný)- Jiř́iček, p. 389, pl. 50, fig. 9-12.

\section{Typhlocypris fossulata fossulata n. ssp.}

Fig. 12a-j

Description. The carapace is very large (close to $2 \mathrm{~mm}$ ) and has a trapezoidal shape in lateral view. The LV clearly overlaps the RV at both ends and the valve in general is remarkably asymmetrical. The RV of the adults has a short straight dorsal margin, slightly steeping towards the anterior. The antero-dorsal margin has a minor concavity at the point where it connects to the dorsal margin and is otherwise rounded. The posterior end is more pointed. The ventral margin is much longer than the dorsal one and almost straight with a wide spread concavity visible on the RV. The greatest width of the carapace is slightly behind mid-length. The surface of the valve shows no ornamentation. The muscle scar consists of a row of three scars with two smaller ones suited closely behind. One larger elongated scar lies above. The inner lamella is well developed in both the anterior-and the posterior end, even visible in juvenile stages. Dimension: $\mathrm{L}=0,37-1,47$ $\mathrm{mm}, \mathrm{H}=0,19-0,78 \mathrm{~mm}$, the minimum sizes include juveniles too.

Remarks. Due to the large size and fragile character of the valve, it is difficult to find unbroken adult specimens. Therefore, most of the material identified is being represented by different juvenile stages that in general show a more sub-triangular rounded outline, especially the LV. It looks like other publications (e.g., Jiř́iček, 1985; Freels, 1980) also described juveniles stages (mainly A1) rather than adult specimens.

Chronostratigraphical and geographical distribution. Jiříček (1985) described the species from the upper Pannonian of the Vienna Basin in Austria, ČSSR and Yugoslavia. It has further been reported from several localities in Turkey, ranging from the upper middle Miocene to upper Miocene (Freels, 1980).

Ecology. The living representatives of this genus occur globally in environments ranging from interstitial water of Australia (Typhlocypris (T.) geratsi) to cave environments in South Korea (Typhlocypris (T.) marimotoi) and the Holarctic (Typhlocypris (P.) albicans) (Karanovic, 2005).

\section{Typhlocypris fossulata reticulata $\mathbf{n}$. ssp.}

Fig. 13a-k

Description. The carapace has a subtrapezoidal shape in lateral view with a noticeable difference between the LV and the RV. The LV overlaps the RV at both ends. The LV shows a short, straight or slightly concave dorsal margin that is gently sloping towards the anterior. The posterior margin is more pointed than the anterior end. The ventral margin is almost straight but shows a slight concavity in the RV and a minor convexity in the LV slightly behind mid-length. The greatest width of the valve is located shortly behind mid-length. The surface of the carapace shows a faint but distinct reticulated pattern 


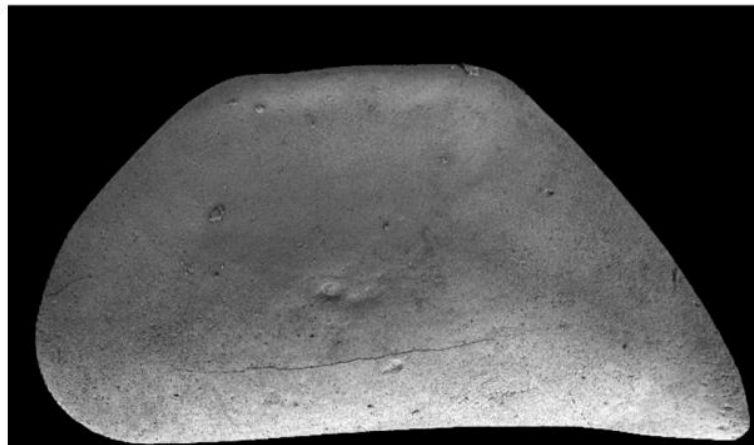

a

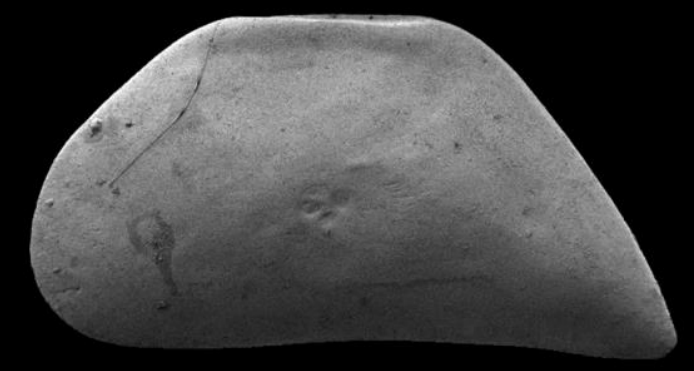

c

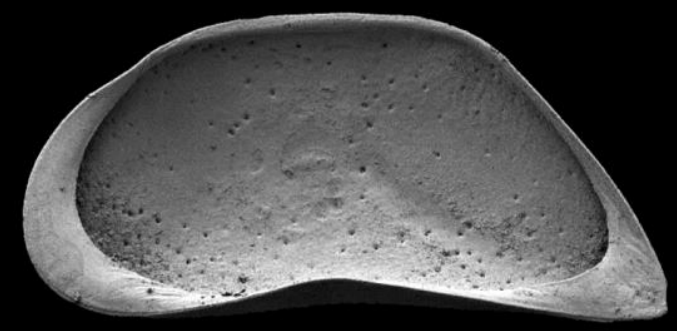

e

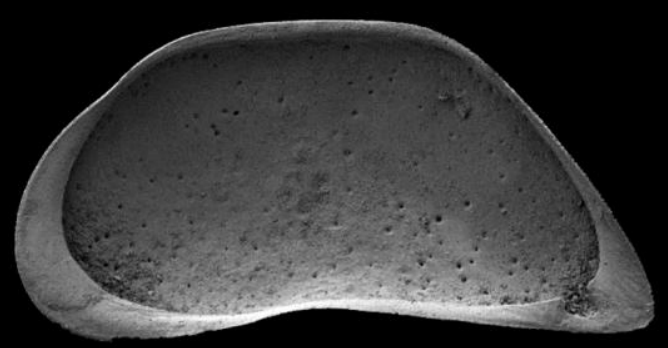

d

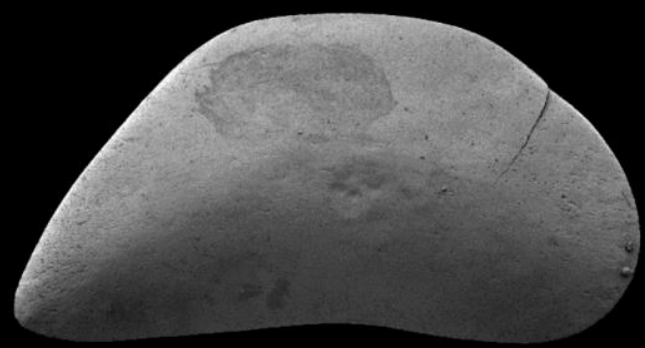

f
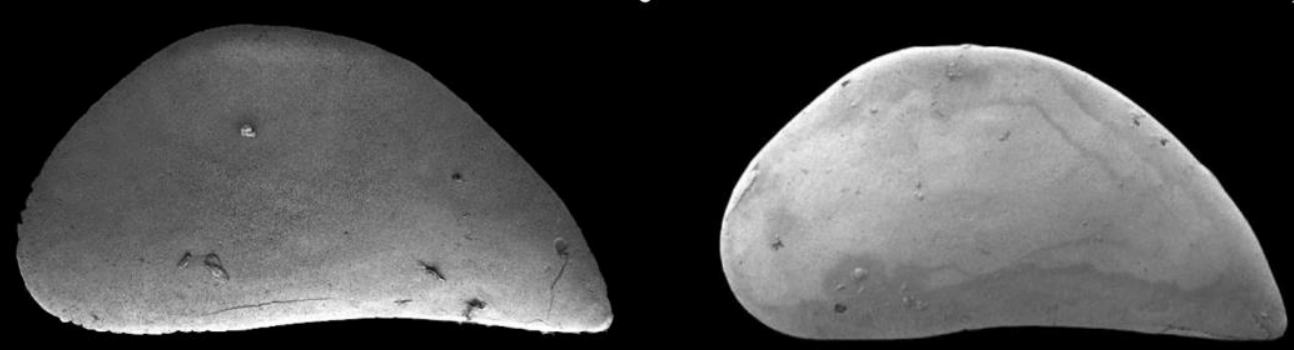

g

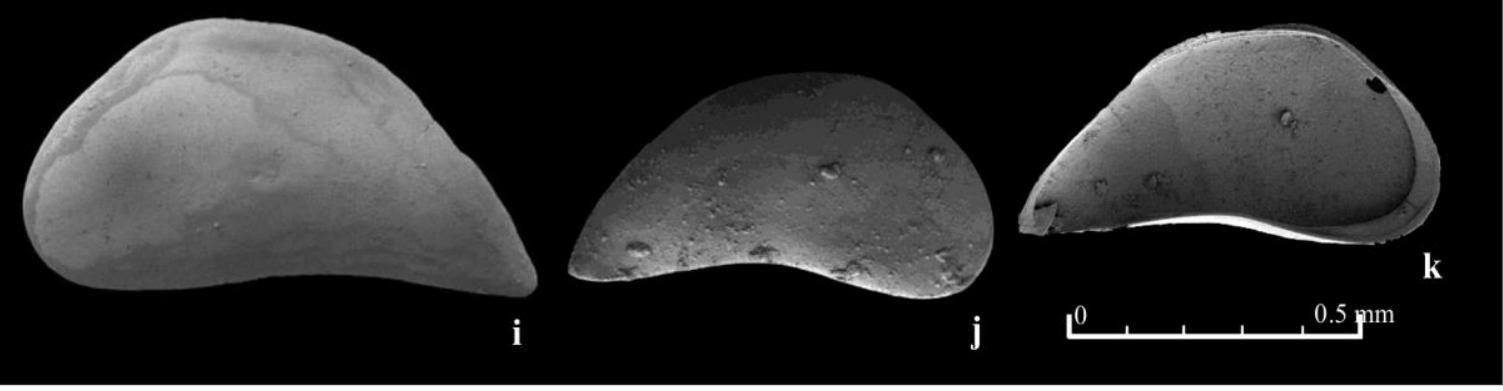

Fig. 11a-k Typhlocyprella sp.; a, c LV, external view; b, f RV, external view; d, e RV, internal view; g, f LV, external view, A1 juvenile; i LV, external view, A2 juvenile; j RV, external view, A3 juvenile; k LV, internal view, A3 juvenile; (all specimens from section $\mathrm{A}$, samples $0 \mathrm{~m}-35,5 \mathrm{~m}$ ). 


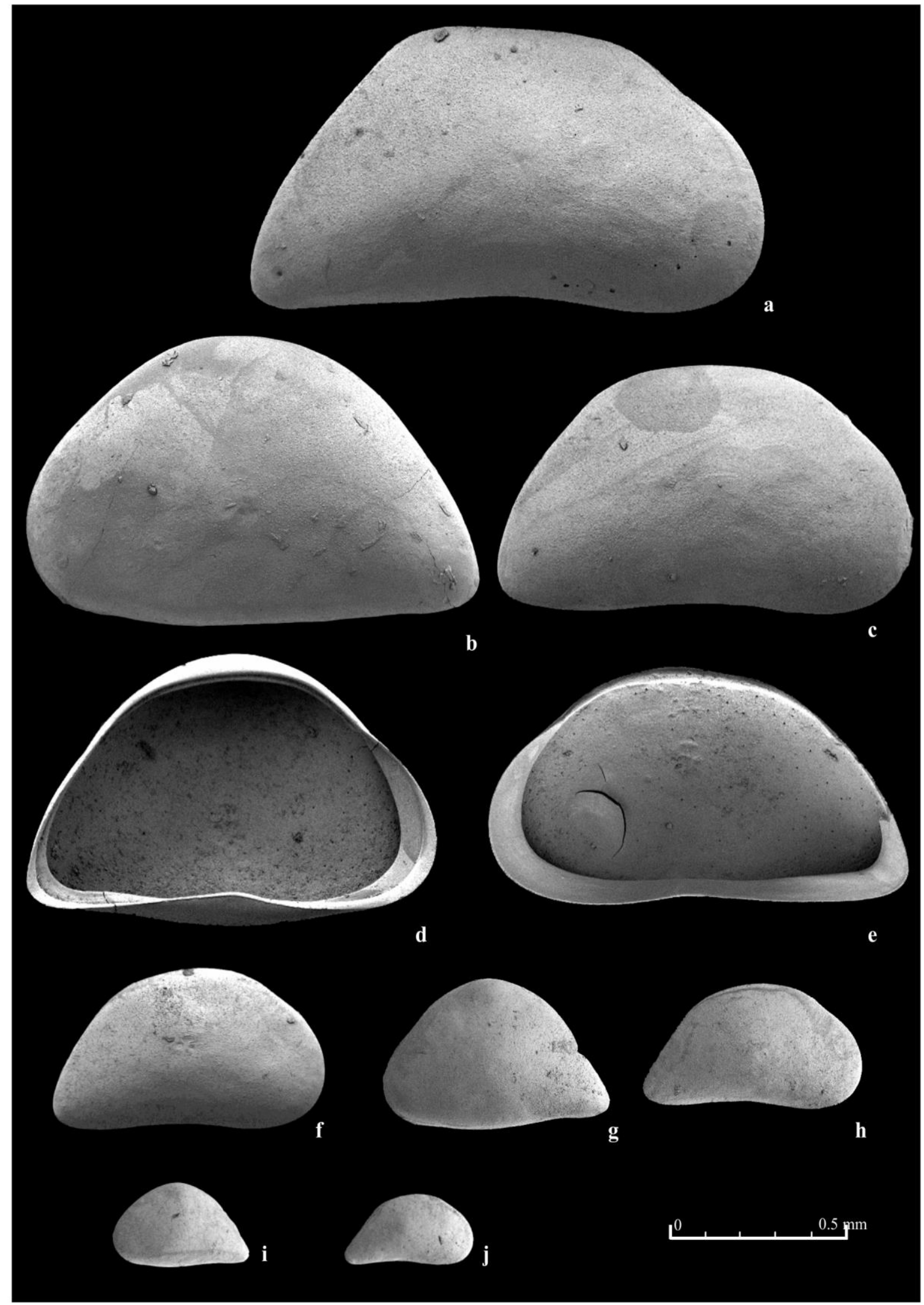

Fig. 12a-j Typhlocypris fossulata fossulata $\mathrm{n}$. ssp.; a RV, external view; $\mathbf{b} \mathrm{LV}$, external view, A1 juvenile; c RV, , external view, A1 juvenile; $\mathbf{d}$ LV, internal view, A1 juvenile; e RV, internal view, A1 juvenile; f RV, external view, A2 juvenile; $\mathbf{g}$ LV, external view, A3 juvenile; h RV, external view, A3 juvenile; i LV, external view, A4 juvenile; $\mathbf{j}$ RV, external view, A4 juvenile; (all specimens from section A, samples $0 \mathrm{~m}-35,5 \mathrm{~m}$ ). 


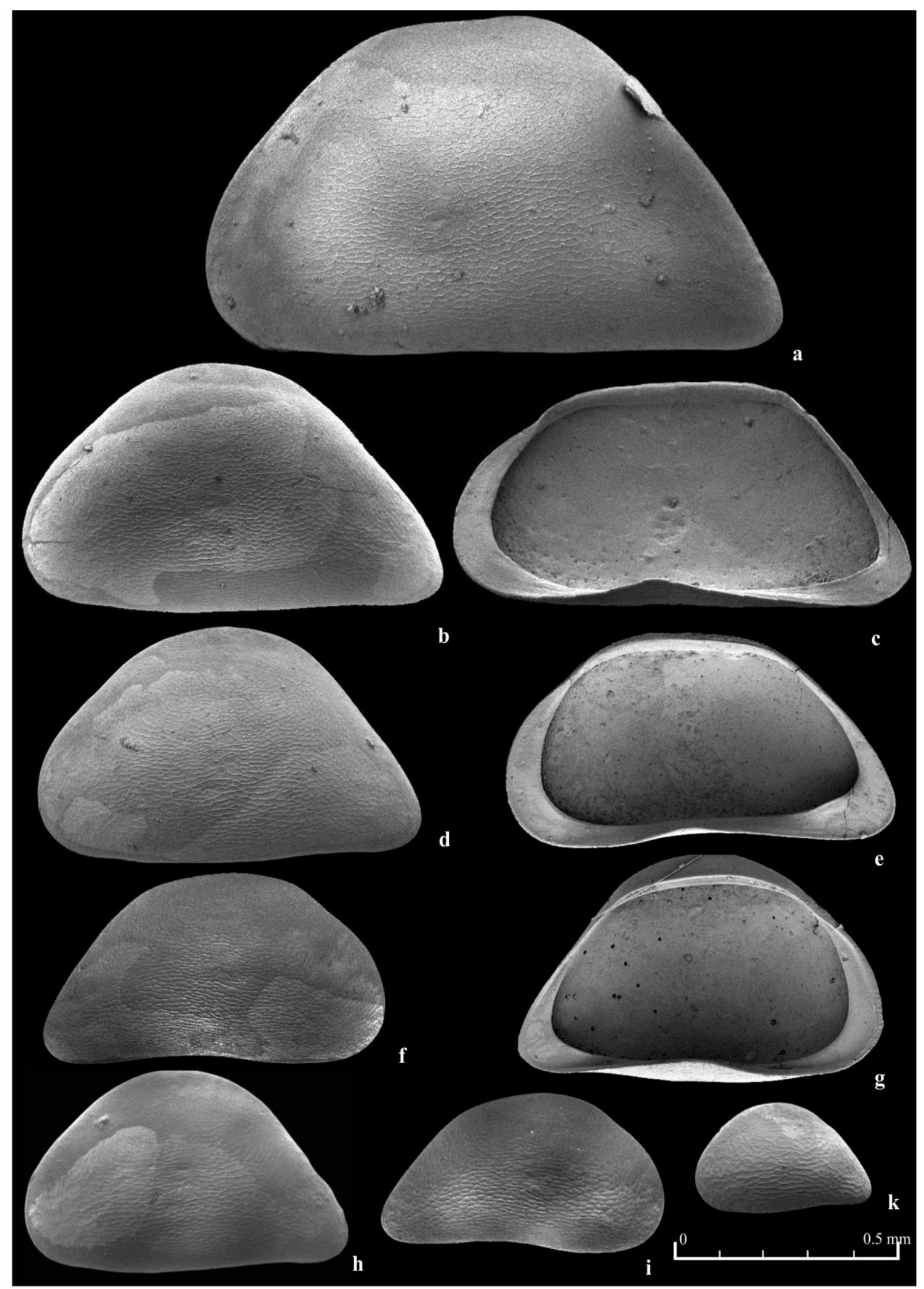

Fig. 13a-k Typhlocypris fossulata reticulata $\mathrm{n}$. ssp a LV, external view; b LV, external view, A1 juvenile; c RV, internal view; d LV, external view, A2 juvenile; e RV, internal view, A1 juvenile; $\mathbf{f} R V$, external view, A2 juvenile; $\mathbf{g}$ LV, internal view, A2 juvenile; h LV, external view, A3 juvenile; i RV, external view, A3 juvenile; k LV, external view, A4 juvenile; (all specimens from section A, sample 3,5 m). 
that appears less pronounced towards the anterior-and posterior end. The muscle scar consists of a row of three scars with two smaller ones suited closely behind. One larger elongated scar lies above. The inner lamella is well developed on the both ends, as well as along the ventral margin. Dimension: $\mathrm{L}=1,04-1,26 \mathrm{~mm}, \mathrm{H}=0,54-0,70$ $\mathrm{mm}$, the minimum sizes include juveniles too.

Remarks. This subspecies has almost the same shape as Typhlocypris fossulata fossulata, but differs from it by possessing a surface coverage, consisting of a fine and slightly elongated reticulation pattern.

Family Ilyocyprididae Kaufmann, 1900

Genus Ilyocypris Brady \& Norman, 1889

\section{Ilyocypris bradyi (Sars, 1890)} Fig.14a-f

1890 Ilyocypris bradyi Sars, p. 59-60.

1962 Ilyocypris bradyi Sars- Jordan et al., p. 87, pl. 6, fig. 73.

2000 Ilyocypris bradyi Sars- Meisch, p. 253, fig. 107AC.

2008 Ilyocypris bradyi Sars- Fuhrmann, p. 264, pl. 4, fig. 10-12.

2012 Ilyocypris bradyi Sars- Fuhrmann, p. 150, pl. 69, fig. 1a-f, 2a-d.

2018 Ilyocypris bradyi- Jorissen et al., p. 15, fig. 12 (2324).

Description. The carapace has a subrectangular shape in lateral view. The dorsal margin gently slopes towards the posterior end and passes onto it in an obtuse angle. The posterior is rounded and continues onto the ventral margin, which is concave mid-length. In the anterodorsal corner the anterior margin is lightly dipping, whereas the rest of the anterior end is rounded. The greatest height is observed in the anterior third of the carapace but anteriorand posterior margins are almost equally wide. The valves bear two distinguishable dorso-median and vertical running furrows on which path between three to five tubercles, set in two rows, can be observed. The tubercles can be more or less prominently developed and in rare cases as spines, located near the dorsal margin. The surface of the valve shows a rounded to slightly elongate and shallow pitted ornamentation that becomes less pronounced towards the anterior-and the posterior margin. On the posterior end minor sized spinules can be present. The inner lamella is narrowly pronounced. Other internal features are excluded from our description due to adverse preservation. Dimension: $\mathrm{L}=0,33-0,85 \mathrm{~mm}, \mathrm{H}=0,30-$ $0,44 \mathrm{~mm}$, the minimum sizes include juveniles too.

Chronostratigraphical and geographical distribution. I. bradyi shows a widespread distribution throughout Europe and has further been reported from Africa, the Middle East, Central Asia, China and North America (Meisch, 2000). This species has been described in the fossil record from the Miocene and Pliocene (Kazmina 1975; Tunoğlu and Çelik 1995) and the Pleistocene to Recent (Meisch, 2000). Inside the Paratethyan domain it has been obtained from a variety of basins, e.g., the upper Maeotian (Bădislava and Toplog sections) and Dacian (Slănicul de Buzău) of the Dacian Basin (Romania) 22
(Floroiu et al., 2016; Jorissen et al., 2018), the upper Productive Series (Surakhany Fm., Kimmerian age) and the Akchagylian-Apsheronian of the South Caspian Basin of Azerbaijan (Van Baak et al., 2013; Lazarev et al., 2019) and the middle Pannonian of the Gelibolu Peninsula (NW Turkey) (Tunoğlu and Ünal, 2001). Further is appears during the Piacenzian-Gelasian in the Tiberino Basin in the Central Apennines of Italy (Spadi et al., 2019) and the Quarternary deposits of the Gorgan plain in North Iran (Yassini, 1987). According to Agalarova et al. (1961) and Mandelstam et al. (1962), it also occurs in the Pliocene and post-Pliocene deposits of Azerbaidjan, Turkmenistan SSR and Caucasus region.

Ecology. The living representatives of $I$. bradyi prefer cooler freshwater springs and can be found in slow flowing waters that fed small ponds, rivers, swamps or lakes (Henderson, 1990; Meisch, 2000). The species has been further mentioned from slightly salty inland waters of Germany, Poland and brackish coastal waters from Belgium (Fuhrmann, 2012).

\section{Ilyocypris gibba (Ramdohr, 1808)}

Fig. $14 \mathrm{~g}-\mathrm{j}$

1808 Cypris gibba- Ramdohr, p. 91, pl. III, figs, 13-17.

1900 Ilyocypris gibba (Ramdohr)- Müller, p. 88, pl. 19. figs. 7,12.

1949 Ilyocypris gibba (Ramdohr)- Schweyer, p. 56, pl. $\mathrm{V}$, fig. 8 .

1969 Ilyocypris gibba (Ramdohr)- Carbonnel, p. 27, plansa 11, fig. 7.

1995 Ilyocypris gibba (Ramdohr)- Olteanu, pl. XXXIV; fig. 10,11 .

2000 Ilyocypris gibba (Ramdohr)- Meisch, p. 245, fig. 104 A-C.

2012 Ilyocypris gibba (Ramdohr)- Fuhrmann, p. 156, pl. 72, fig. 1a-f, 2a-d.

2013 Ilyocypris ex. gr. gibba (Ramdohr)- Van Baak et al., p. 124, fig. 4a, 7,8, p. 125, fig. 5a, 6,7.

2015 Ilyocypris gibba (Ramdohr)- Van Baak et al., p. 602, fig. 7b, 29-32.

Description. The carapace has a subquadrate to subrectangular shape in lateral view. The dorsal margin runs straight and parallel to the ventral margin that is concave mid-length. The anterior-and posterior ends are broadly rounded and denticulate. The valves surface is coarsely puncated and traversed by two vertical running furrows. Tubercles are not present. Due to poor preservation no internal features could be described. Dimension: $\mathrm{L}=0,53$ $-0,81 \mathrm{~mm}, \mathrm{H}=0,31-0,43 \mathrm{~mm}$, the minimum sizes include juveniles too.

Chronostratigraphical and geographical distribution. Today I. gibba is showing a widespread distribution throughout Europe, Africa, the Middle East, Central Asia and both North and South America (Meisch, 2000). In the fossil record I. gibba has been described from the lower Miocene and Pliocene of Central Anatolia (Tunoğlu \& Celik, 1995) and in Plio-Pleistocene deposits of the Dacian Basin (Romania) (Van Bakk et al., 2015; Jorissen et al., 2018). It has also been mentioned by Agalarova et al. (1961) and Mandelstam and Schneider (1963) within Pliocene and post-Pliocene deposits of Azerbaijan, 

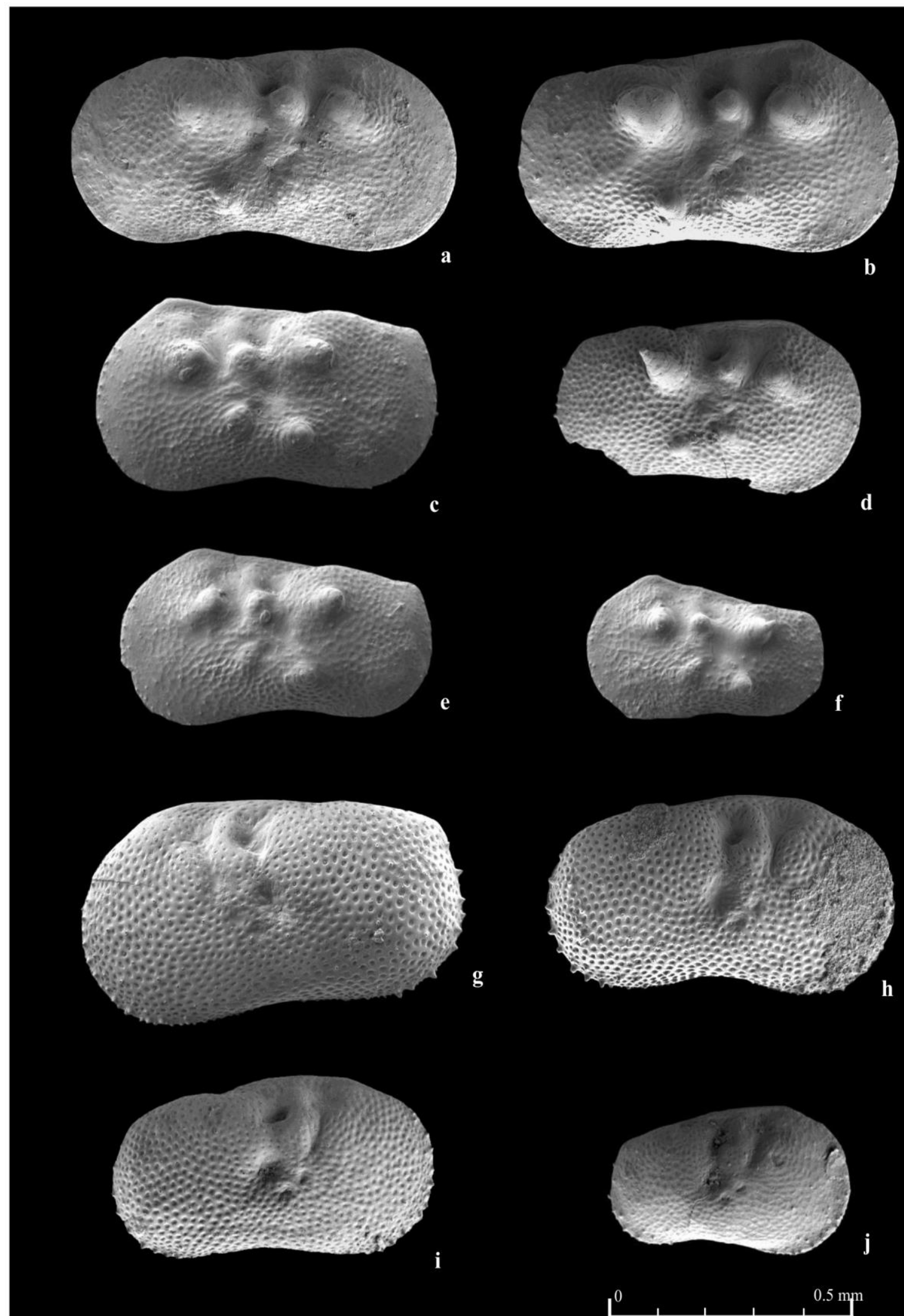

Fig. 14a-f Ilyocypris bradyi; a, b RV, external view, c LV, external view; d RV, external view, A1 juvenile; e LV, external view, A1 juvenile; f. LV, external view, A2 juvenile; g-j Ilyocypris gibba; g LV, external view; h RV, external view; i RV, external view, A1 juvenile; $\mathbf{j}$ RV, external view, A2 juvenile; (all samples from section B; a-f from 29,5 m and g-j from sample $184,5 \mathrm{~m})$. 
Turkmenistan SSR, Kirmea and Caucasus.

Ecology. Recent living specimens of I. gibba preferably occur in small permanent water bodies with a finemudded, clayey-or sandy substrate. The species has also been reported from temporary pools, springs, slightly salty waters and rice fields (Meisch, 2000). Together with $C$. ex. gr. torosa and C. neglecta Sars it has been described from freshwater assemblages from the Romanian stage of the Slănicul de Bazău section in the Dacian Basin (Van Baak et al., 2015). Living specimens are ecologically characterized as meso- to polythermohaline, rheoeuryplastic with oligohalophilic summer forms (Meisch, 2000; Fuhrmann, 2012).

Suborder Cyherocopina Baird, 1850

Superfamily Cytheroidea Baird, 1850

Family Cytherideidae Sars, 1925

Genus Cyprideis Jones, 1857

\section{Cyprideis pannonica (Méhes, 1908)}

Fig. 15a-j

1908 Cytheridea pannonica n.sp.- Méhes, p. 61, Tab. XI, Fig. 7.

1929 Cyprideis pannonica Méhes- Zalányi, p. 73, textfig. 35-1.

1990 Cyprideis pannonica (Méhes)- Sokač, p. 692.

2013 Cyprideis pannonica (Méhes)- Stoica et al., p. 140, pl. 2, fig. 1 .

Description. The carapace has an elongate to subovate shape in lateral view. The dorsal margin is gently arched and slightly inclined towards the posterior. The posterior end is somewhat narrower than the obtuse rounded anterior margin. Both, the anterior-and the posterior end, pass smoothly onto the almost straight running ventral margin. The greatest width of the carapace is slightly in front of the mid-length. The valves surface is smooth and randomly distributed normal sieve-pores are present. Sexual dimorphism is occurring and females show a more ovalshape, whereas male valves have a narrower posterior part. The marginal zone is moderately developed. The internal features do not deviate to those of other Cyprideis species. Dimension: $\mathrm{L}=0,48-1,04 \mathrm{~mm}, \mathrm{H}=0,30-$ $0,58 \mathrm{~mm}$, the minimum sizes include juveniles too.

Chronostratigraphical and geographical distribution. This species is commonly found inside Pannonian deposits of the Pannonian Basin of Hungary, Austria, Yugoslavia and Czechoslovakia (Sokač, 1990). It has further been described from lower Pontian sediments of the Dacian Basin (Stoica et al., 2013). Outside the Paratethys it is mentioned from Lago-Mare deposits of the Sorbas Basin in SE Spain (Gliozzi et al., 2005), the Messinian sediments of the Djebel Kechabta section in northern Tunisia (Benson, 1976) and the early Pannonian of the Gelibolu Peninsula in NW Turkey (Tunoğlu, 2001).

\section{Cyprideis ex. gr. torosa (Jones, 1850)} Fig. 16a-j
1925 Cyprideis littoralis nov. comb. - Sars, p. 9: 155; pls. 71, 72:1.

1996 Cyprideis torosa Jones- Boomer et al., p.83, fig. 4, $\mathrm{J}-\mathrm{N}$.

2000 Cyprideis torosa Jones- Meisch, p. 459, fig. 188189.

2005 Cyprideis torosa Jones- Matzke-Karasz \& Witt, p. 128, pl. 3, fig. 8-11.

2005 Cyprideis torosa $f$. torosa Jones- Viehberg, p. 67, fig. 7,8 .

2015 Cyprideis ex. gr. torosa- Van Baak et al., p. 603, fig. 8 (19-27).

2018Cyprideis ex. gr. torosa- Jorissen et al., p. 13, fig. 10 (9-20).

Description. The carapace has a subovate to elongated shape in lateral view and a slightly arched dorsal margin that gently slopes towards the rounded posterior end. The anterior border is broadly rounded as well but weakly cut off in the upper part. The greatest width of the carapace is slightly in front of the mid-length. The male valves are a bit more elongated and narrower in the posterior area. The valves surface varies from having a fine reticulation to pitted ornamentation and can have up to 6 tubercles, variable in form, number and position. They do not seem to occur symmetrical and are frequently absent. The inner lamella is narrow. The muscle scar and the hinge are typical for the genus. Dimension: $\mathrm{L}=0,69-1,04 \mathrm{~mm}, \mathrm{H}=$ $0,37-0,57 \mathrm{~mm}$, the minimum sizes include juveniles too. Chronostratigraphical and geographical distribution. C. torosa is one of the most common ostracod species observed in brackish coastal waters of Europe, Western and Central Asia, the Mediterranean region of North Africa, the Middle East as well as North America and Central Africa (Meisch, 2000). The fossil record goes back to the Miocene. C. torosa first appeared in the Eastern Paratethys in the late Volhynian (early Sarmatian s.l.) and in Sarmatian s.str. in the Central Paratethys (Carbonnel and Jiříček, 1977; Jiříček, 1983). The species has been commonly observed in Khersonian - Romanian brackish water deposits of the Slănicul de Buzău section as well as in the freshwater sediments of Romanian deposits (Van Baak et al., 2015; Jorissen et al., 2018; Lazarev et al., 2020 (submitted)). In the Mediterranean the species was first recognized in middle Tortonian brackish water deposits of Crete in the Eastern part of the Mediterranean (Sissingh, 1974).

Ecology. C. torosa inhabits mainly marine brackish waters with fluctuating salinities but is also found in a greater range of salinities from freshwater to fully marine and even hypersaline waters (over $60 \%$ ) (Meisch, 2000). It occurs in coastal ponds, lakes, marginal marine environments and prefers mud or sandy substrates but also can be found on pure sand or algae (Meisch, 2000) down to depths of $30 \mathrm{~m}$. Salinities ranging between 2 - 16,5\% are reported to offer the optimal conditions for population development (Meisch, 2000; Wagner, 1964).

Family Hemicytheridae Puri, 1953

Genus Tyrrhenocythere Ruggieri, 1955 

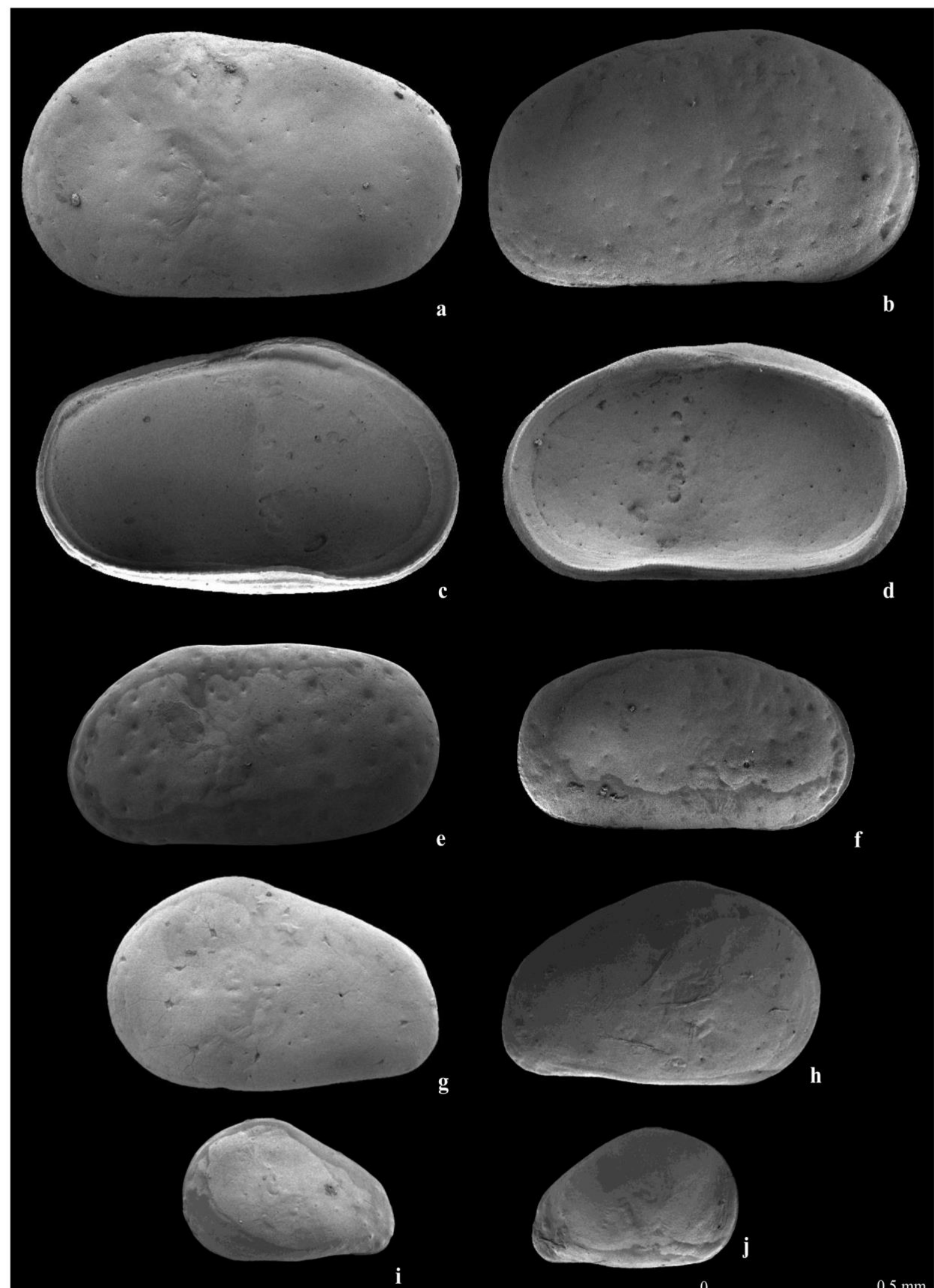

i
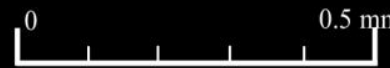

Fig. 15a-j Cyprideis pannonica; a LV, external view, $\circ$; b RV, external view, $q$; c LV, internal view, $\circ$; d RV, internal view, o; e LV, external view, small sized adult; $\mathbf{f}$ RV, external view, small sized adult; $\mathbf{g}$ LV, external view, A1 juvenile; $\mathbf{h}$ $\mathrm{RV}$, external view, A1 juvenile; i LV, external view, A2 juvenile; j RV, external view, A2 juvenile; (all specimens from section A, samples $0 \mathrm{~m}-35,5 \mathrm{~m})$. 

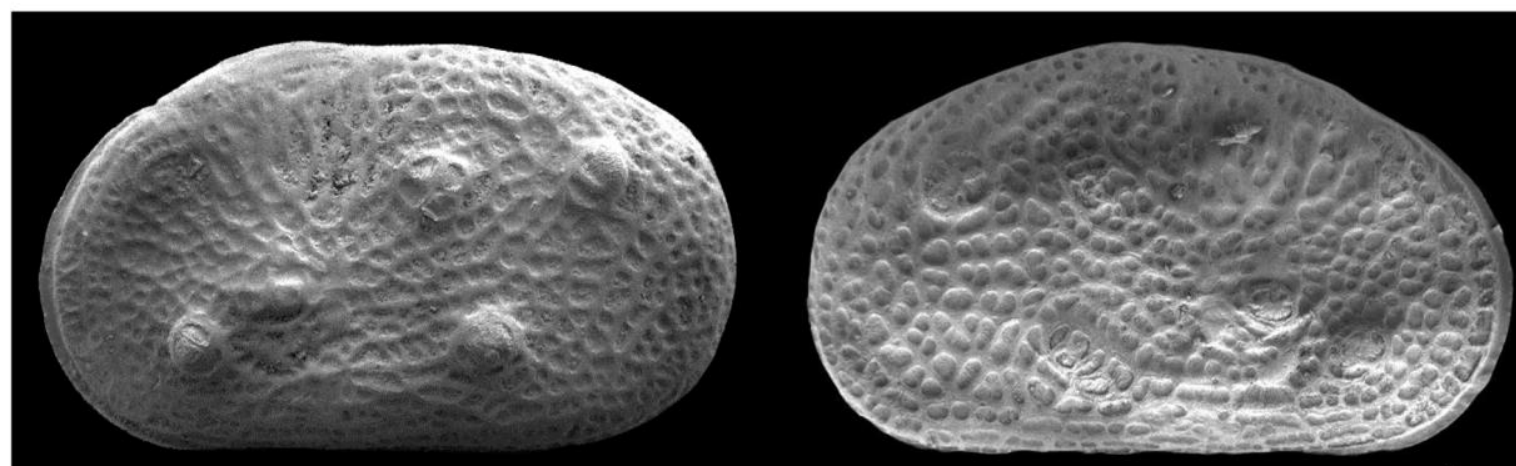

a
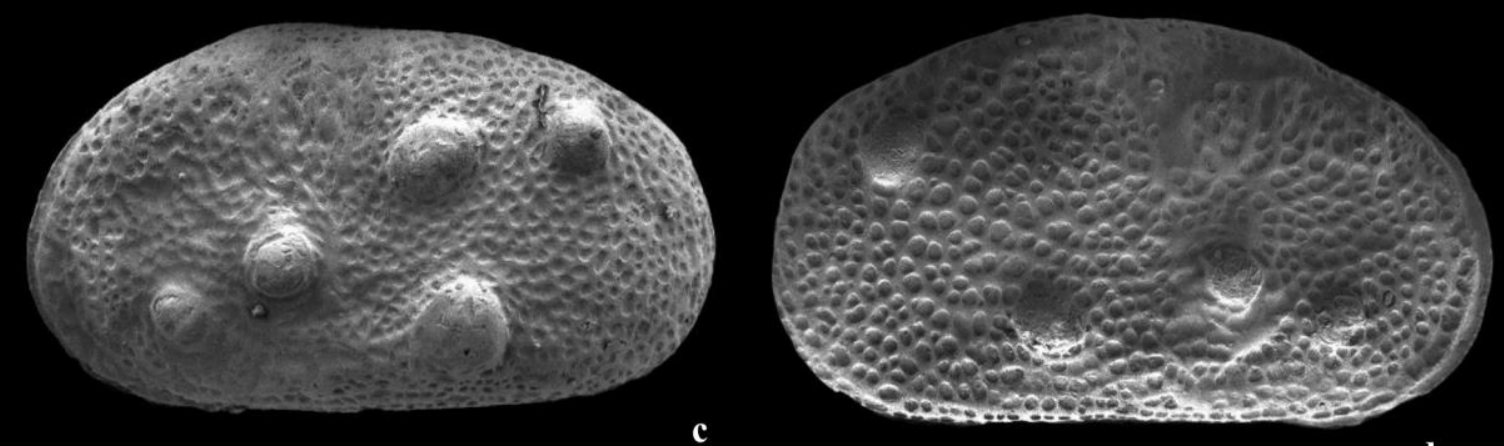

c
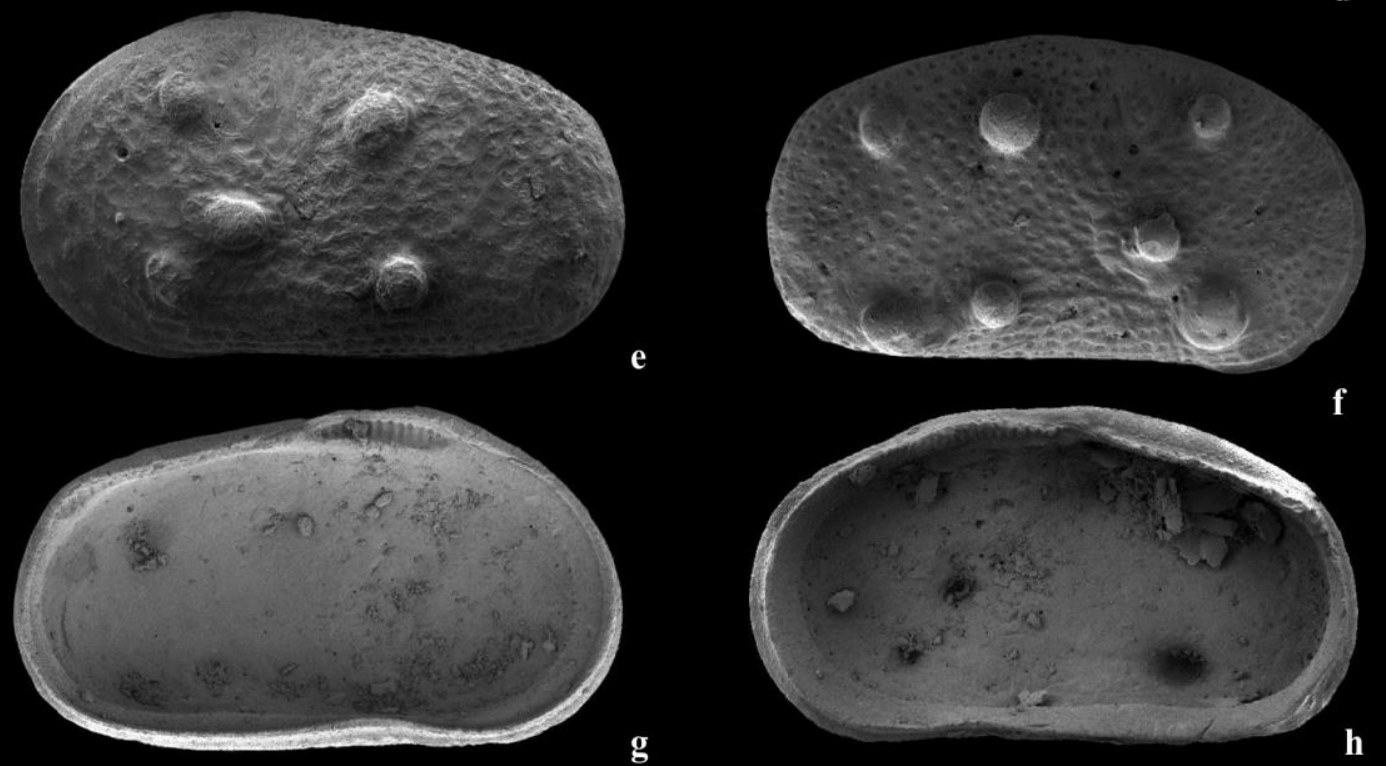

g
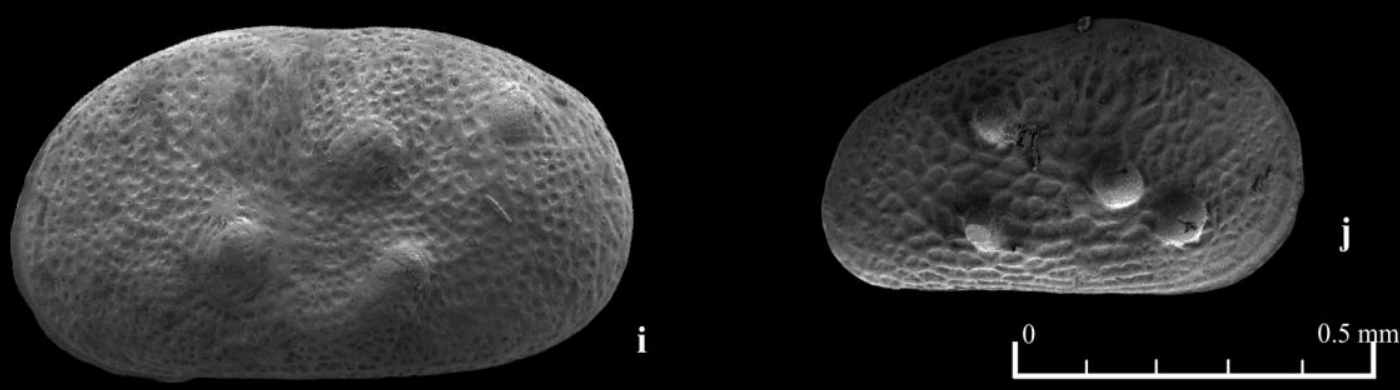

Fig.16a-j Cyprideis ex. gr. torosa; a, c, i LV, external view, $\circ$; b, d RV, external view, $\circ$; e LV, external view, $\circ$; f RV, external view, + ; $\mathbf{g ~ L V}$, internal view; $\mathbf{h} \mathrm{RV}$, internal view; $\mathbf{j}$ RV, external view, A1 juvenile; (all specimens from section B, samples 55,5 m-61,5 m). 
Tyrrhenocythere pontica (Livental) in Agalarova et al., 1961

Fig. 17a-e

1961 Cythereis pontica Livental in litt.- Agalarova et al., 1961 (pl. LXXXII, figs. 2, 3a, b, c; pl. LXXXV, figs. 2-4.

1975 Trachileberis pontica (Livental)- Vekua, pl. XV, figs. 1 a,b, 2 a, b, 4.

1977 Tyrrhenocythere pontica (Livental)- Krstić, pl. II, figs. 1, 2.

1982 Tyrrhenocythere pontica (Livental)- Olteanu, p. 53, pl. VI, figs. 1, 2.

1989 Tyrrhenocythere pontica (Livental)- Olteanu, pl. XII, figs. 1, 2.

1989 Tyrrhenocythere pontica (Livental)- Stancheva, p. 20 , pl. 6 , fig. 4.

1995 Tyrrhenocythere pontica (Livental)- Olteanu, p. 301 , pl. 25,fig. 8.

1999 Tyrrhenocythere pontica (Livental)- Gliozzi, p. 201, pl. II, fig. c-1; pl. IIId.

2001 Tyrrhenocythere pontica (Livental)- Olteanu, pl. II, fig. 1.

2013 Tyrrhenocythere pontica (Livental)- Van Baak et al., p. 124, pl. 4 b, 21.

Description. The valve has an oblong shape in lateral view with the maximum height within the anterior third. The dorsal margin is almost straight, slightly arched on male valves and more or less inclined towards the posterior, whereas in females it is slightly concave. The anterior margin is broadly rounded and connects smoothly to the ventral margin that is lightly concave which can best be seen from the internal view. The posterior margin is weakly pointed and bears a more or less pronounced shoulder, which starts midheight and is rounded underneath and continues smoothly onto the ventral margin. Above the apex the posterior is concave. Along the ventral margin runs a well pronounced ridge (crest) that originates at the lower part of the anterior margin and ends abruptly on the posterodorsal angle axis. The crest is more elongated in males and a bit shorter and higher up at the posterior in females. Juvenile stages have a shorter crest but visibly located higher and pointed towards the posterior end. The surface of the valve is covered with unequally sized polygonal meshes that increase in size towards the anterior-and posterior margin. Within the main polygonal network, a secondary ornamentation is observed, especially in areas close to the anterior and posterior. Along the rim, the ornamentation forms parallel rows. The hinge is heterodont. Dimension: $\mathrm{L}=0,52-$ $1,08 \mathrm{~mm}, \mathrm{H}=0,32-0,60 \mathrm{~mm}$, the minimum sizes include juveniles too.

Chronostratigraphical and geographical distribution. Inside the Eastern Paratethys this species is known from late Miocene - early Pleistocene records. It has been described from middle Pontian - early Dacian of the Dacian Basin of Romania and Bulgaria, Pontian deposits of the Euxinic Basin of southern Ukraine and Turkey and the Apsheronian of the South Caspian Basin of Azerbaijan (Agalarova et al., 1961; Vekua; 1975; Krstić, 1977; Olteanu, 1982, 1990; Tunoğlu and Ünal 2001; Van Baak et al., 2013). Outside Paratethys the species has been mentioned, e.g., from upper Messinian Lago-Mare deposits of the Le Vicenne Basin in Italy (Gliozzi, 1999), Malaga Basin of Spain (Guerra-Merchán et al., 2010), the latest Miocene or Early Pliocene of the greek island Kos (Guernet et al., 1976), the latest Messinian of Corsica and the Rhone Basin of France (Carbonnel, 1978). It frequently occurs in the Quaternary of the Danube Delta (Olteanu, 1995).

Ecology. The living representatives of the genus are generally occurring in mesohaline waters $(9-13 \%$ ) but also tolerate lower salinities. They can be found at a variety of depths ranging from 0-30m (Krstić, 1977 for T. amnicola (Sars)) down to 200m in the Caspian Sea (Yassini and Ghahremann, 1976 for T. scitula). Krstić (1977) estimated that the fossil species of Tyrrhenocythere lived in shallow waters with a salinity ranging from $5-15 \%$.

\section{Tyrrhenocythere aff. pontica}

(Livental) in Agalarova et al., 1961

Fig. $17 f-j$

Description. This species is quite similar to $T$. pontica with the difference that males are more elongated and display an almost parallel running dorsal-and ventral margin. Also, the posterior end is more rounded and without the distinct shoulder. The ornamentation is the same, but the ventral crest in general appears much shorter than in T. pontica. Dimension: $\mathrm{L}=0,28-0,93 \mathrm{~mm}, \mathrm{H}$ $=0,17-0,49 \mathrm{~mm}$, the minimum sizes include juveniles too.

\section{Tyrrhenocythere aff. ruggierii (Devoto, 1967)} Fig. 17k-1

1967 Tyrrhenocythere ruggierii- Devoto, p. 31-35, figs. 5-8.

1982 Tyrrhenocythere ruggierii Devoto- Olteanu, p. 54, pl. 1, figs. 1-6.

1999 Tyrrhenocythere ruggierii Devoto- Gliozzi, p. 202, pl. III, fig. a-c.

2016 Tyrrhenocythere cf. ruggierii Devoto- Stoica et al., p. 862, pl. 3, 5-9.

Description. The carapace is heavily calcified and shows an oblong-oval outline. The anterior margin is broadly rounded and has its highest point at the anterodorsal corner. The dorsal margin is inclined backwards and continues smoothly onto both the anterior-and the posterior end. The ventral margin shows a slight convexity with a distinct concavity close to its anterior end. The posterior end has a weakly pronounced shoulder that starts midheight and is rounded in its lower part. Above the shoulder the posterior margin is slightly concave. The eye spot is well developed and positioned at the anterior end of the dorsal margin on the otherwise almost smooth surface of the valve. Only close to the posterior-and the anterior end medium-sized longitudinally running meshes and small sized cells and pits are occurring. There is a transversal rim that has its maximum development along the posteroand anteroventral area. Branching pore channels within the broad marginal zone are present. The muscle scar pattern and the hinge structure are genus typical. Dimension: $\mathrm{L}=1,09-1,10 \mathrm{~mm}, \mathrm{H}=0,43-0,64-\mathrm{mm}$, the minimum sizes include juveniles too. 


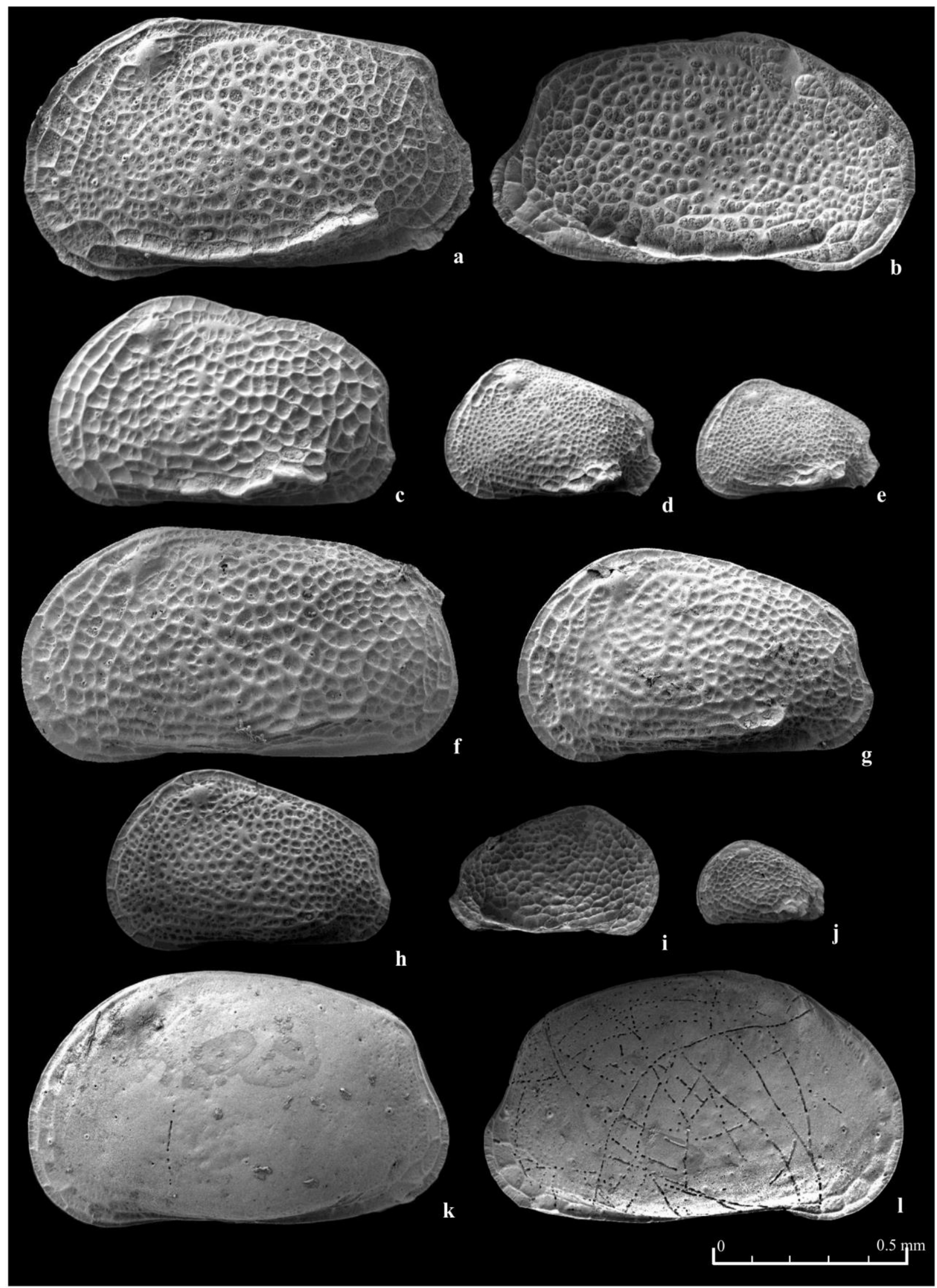

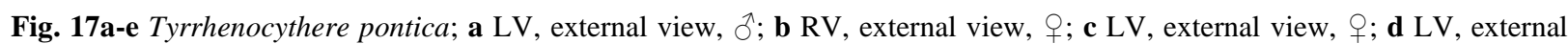
view, A2 juvenile; e LV, external view, A3 juvenile; f-j Tyrrhenocythere aff. pontica; f LV, external view, ô; $\mathbf{g}$ LV, external view, ; $\mathbf{h}$ LV, external view, A1 juvenile; i RV, external view, A2 juvenile; $\mathbf{j}$ LV, external view, A3 juvenile; k, $\mathbf{l}$ Tyrrhenocythere aff. ruggierii; $\mathbf{k}$ LV, external view, + ; l RV, external view, $\circ$; (specimens a-e from section B, samples 36,6 m-61,5 m; specimens f-j from section A, sample $15 \mathrm{~m}$; specimens k-1 from section B, sample $65 \mathrm{~m}$ ). 
Remarks. Krstić (1977) is assuming that T. ruggierii is probably a synonymous with $T$. truncata (Schneider) that has been described in a variety of Paratethyan Basins. Carbonnel (1978) and Olteanu (1982) are not agreeing with the hypothesis of Krstić and consider it a valid species. On the other hand, Krstić (in Krstić and Stancheva, 1990) described Tyrrhenocythere triebeli, from the Novorossian of North Greece, Strimon basin that has many similarities with $T$. ruggieri. A morphological similar looking species was described by Olteanu (1982) as Tyrrhenocythere dacicum from Pontian sediments of the Dacian Basin.

Chronostratigraphical and geographical distribution. This species is not mentioned often in the Paratethys domain and has only been described by Olteanu (1982) from the middle-and late Pontian of the Dacian Basin. Outside the Paratethys the species has been reported from the Spanish Lago-Mare (Stoica et al., 2016), the late Messinian deposits of the Vera Basin from Spain (Carbonnel, 1978) and the late Messinian of the Vicenne Basin in Italy (Gliozzi, 1999).

Ecology. The ecology resembles the preferences of Tyrrhenocythere pontica.

\section{Tyrrhenocythere sp.} Fig. 18a-k

Description. The carapace has a rectangular to oblongoval shape in lateral view and a distinct eye spot at the anterodorsal corner. The male valves are slightly longer and show almost parallel running dorsal-and ventral margins, while female valves tend to be shorter with a dorsal margin slightly sloping towards the posterior. The anterior margin is broadly rounded and passes smoothly onto the ventral end. In the anterior third, the ventral margin shows a concavity more visible on the RV. The posterior end bears a more or less pronounced shoulder, mainly visible on RV, and is rounded underneath. Above, it continues slightly concave onto the almost straight running dorsal margin. The outer margin of the carapace is surrounded by a fine rim that stretches from the anterior end along the entire ventral margin and stops in the middle of the posterior end. There it is extending onto the shoulder and broadens it. The valves surface is covered with small to medium sized pits. Towards the posterior-and the anterior end the ornamentation is turning into medium-sized longitudinally running meshes. The marginal zone is broad, especially along the anterior margin, and displays a number of branched pore channels. The muscle scar consists of two rows of imprints, owing to the division of the two median imprints into upper and lower ones. The hinge is well developed and heterodont with a strong single posterior-and anterior tooth. Dimension: $\mathrm{L}=0,44-$ $1,12 \mathrm{~mm}, \mathrm{H}=0,27-0,58 \mathrm{~mm}$, the minimum sizes include juveniles too.

Remarks. Tyrrhenocythere bailovi (Livental) in Mandelstam et al., 1962, described from the Caspian region (Yassini, 1986), displays a similar type of ornamentation but with finer and closer arranged pits and without the medium-sized parallel running meshes at the anterior-and posterior end. Also, the outline of $T$. bailovi is more pointed towards the posterior in both males and females and we therefore renounce the assigning of this species.
Family Leptocytheridae Hanai, 1957

Genus Leptocythere Sars, 1925

\section{Leptocythere sp. 1}

Fig. 19a-1

Description. This species has a small carapace (less than $0,5 \mathrm{~mm}$ ) that is elongated to subovate in lateral view. It has two large and heavy ornate tubercles situated slightly behind mid-length each close to the ventral-and dorsal margin. The maximum height of the carapace is near the anterior cardinal angle. The anterior end is larger, obtusely rounded, flattened, with a clear limb and smoothly transfers onto the ventral margin. The almost straight running dorsal margin is sloping to the posterior end, that is obtusely rounded and narrower compared to the anterior end. The two tubercles are covered with a coarse reticulated polygonal pattern that extends around the tubercles, but fades towards the anterior-and posterior ends. Ventrally, the net ornamentation tends to be arranged in parallel rows. The rest of the valves surface is smooth but shows several cone-shaped pores (conuli), concentrated in the posterior area. The inner lamella is broadly developed, especially in the anterior part creating a large vestibulum. The two tubercles are hollow internally. The tooth plate presents a narrow crenulate median bar on the $\mathrm{RV}$, bordered by two elongated subdivided teeth. Dimension: $\mathrm{L}=0,40-0,46 \mathrm{~mm}, \mathrm{H}=0,21-0,23 \mathrm{~mm}$, the minimum sizes include juveniles too.

Remarks. This species has a similar shape as Leptocythere bicornis Livental described from the Pliocene of the Caspian region (in Agalarova et al., 1961). They even share the prominent tubercles but L. bicornis lacks the coarse polygonal meshes on the tubercles and around them.

Ecology. The genus Leptocythere has a euryhaline distribution and species are typically occurring in estuarine (brackish) waters. Others have been reported from shallow marine (littoral) environments (Olteanu, 1978).

Amnicythere ex. gr. multituberculata (Livental, 1929) Fig. 20a-h

1929 Cythere multituberculata nov. sp.- Livental, p. 14, pl. 1, figs. 36-38.

1962 Cythere multituberculata Livental- Mandelstam et al., p. 299, pl. 37, fig. 6.

1972 Leptocythere multituberculata Livental- Sokač, p. 71, pl. 32, fig. 14-15.

1973 Leptocythere (Amnicythere?) multituberculata (Liv.)- Krstić, p.86; text-fig. 116; pl.III, fig. 8.

1986 Leptocythere multituberculata (Livental)- Yassini, p. 27, pl. 10, fig. 1-3.

1989 Leptocythere (?) multituberculata (Livental)Olteanu, pl. VI. fig. 5-6.

1995 Amnicythere multituberculata (Livental)- Olteanu, p.345, pl. XVI, fig. 1-8.

2011 Leptocythere (Amnicythere) multituberculata (Livental)- Olteanu, p. 159, pl. IX, fig.5.

2013 Amnicythere multituberculata (Livental)- Van Baak et al., p. 124, fig. 4, 16.

2016 Amnicythere multituberculata (Livental)- Van Baak et al., p. 67, fig. 4a, 9-10. 
Description. The species has an elongated shape and four large tubercles and, in some cases, a slightly inflated posterior area. The tubercles as well as the interspaces between them are covered with a more or less pronounced but distinct wide-sized mesh pattern that fades towards the anterior end. In some rare cases the primary reticulation is filled with a secondary, finer ornamentation. The dorsal margin is almost straight, inclining slightly towards the posterior and passing smoothly onto the rounded anterior border in an obtuse angle. The transition onto the anterior border forms a ledge through the "hinge ear". Both anterior-and posterior borders merge smoothly with the ventral margin, which is antero-medially concave. Both, along the anterior-and posterior margin a number of irregular distributed small sized conulus pores are present. The hinge is typical for the genus and is pronounced as a smooth median bar. In adults, the inner lamella is well developed both anteriorly and posteriorly and along the ventral margin. Dimension: $\mathrm{L}=0,61-0,68 \mathrm{~mm}, \mathrm{H}=$ $0,33-0,35 \mathrm{~mm}$, the minimum sizes include juveniles too. Remarks. The species shows a large variation in ornamentation, possibly induced by environmental fluctuations.

Chronostratigraphical and geographical distribution. The species is described from the Pontian of Bulgaria and inside the Pannonian Basin at the lower Pontian level (Sokač, 1972). In the Dacian Basin it appears in the Bosphorian (late Pontian), reaching a maximum frequency at the Getian (early Dacian) time. It occurs only sporadically in the Parscovian (late Dacian; Olteanu, 1995). It has further been mentioned from the Pontian of the Bădislava - Topolog area in Romania (Floroiu et al., 2011). Inside the Eastern Paratethys L. multituberculata is widely present in South Caspian basin: from the Pontian (Adzhiveli section) and Akchagylian - Aspheronian deposits (Goychay and Hajigabul sections) of Azerbaijan (Van Baak et al., 2013, 2016; Lazarev et al., 2019) and from Aspheronian of Turkmenistan (Agalarova et al., 1961; Mandelstam et al., 1962; Yassini, 1986). It is also known from the Pontian of the Taman Peninsula in Russia (Stoica et al., 2016), successions of Pontian age in the eastern Black Sea region of Turkey (Tunoğlu and Ünal, 2001) and Lago Mare (late Messinian) deposits of Italy and Sicily (Gliozzi et al., 2005; Grossi et al., 2015).

Ecology. L. multituberculata has been mentioned by Grossi et al. (2015) as part of a "CyprideisLoxoconchidae assemblage", representing low mesohaline and shallow water conditions. Living representatives of the species were described by Gofman (1966), Yassini (1986) and Gliozzi and Grossi (2008) throughout nowadays remnants of the Paratethys (Black Sea, Caspian Sea, Aral Sea) at salinities of 11,5-18,25\%.

\section{Amnicythere striatocostata (Schweyer, 1949)}

$$
\text { Fig.21a-i }
$$

1949 Cythere striatocostata sp. n.- Schweyer, p.27-28, pl. 9 , fig. 8 .

1961 Leptocythere striatocostata (Schweyer)- Agalarova et al., p. 108, pl. 68, fig. 1-3a-b.

1976 Leptocythere striatocostata (Schweyer)- Yassini \& Ghahreman, p. 182, pl. 2, fig. 4.
1978 Leptocythere striatocostata (Schweyer)- Olteanu, p. 1019 , pl. 4. fig. 7.

1986 Leptocythere striatocostata (Schweyer)- Yassini, p. 31, pl. 11, fig. 8-10.

1989 Amnicythere striatocostata (Schweyer)- Olteanu, pl. VI, fig. 9.

2010 Amnicythere striatocostata (Schweyer, 1949) Stancheva, 1990- Boomer et al, p. 129, pl.1, fig. 10.

2013 Leptocythere striatocostata (Schweyer)- Ter Borgh et al., p. 106, fig. 8, 20.

2016 Amnicythere striatocostata (Schweyer)- Van Baak et al., p. 66, fig. 3b, 13-14.

Description. The carapace has an elongated shape in lateral view and is ornamented with more or less pronounced parallel running, narrow ribs that run longitudinally from the posterior margin and fade towards the anterior half of valve. The ribs in some cases merge and form longitudinally, elongated polygons. The anterior part of the valves surface is smooth and thin. Small, wide spaced conulus pores are displayed along the anterior-and posterior borders. The dorsal margin slopes gently towards the posterior that is broadly rounded but slightly compressed. The ventral margin is slightly concave midlength and continues smoothly onto the rounded anterior margin which is flattened but wider than the posterior. The marginal area is broad and pierced by widely spaced branching pore canals. The inner lamella is broadly developed, especially along the anterior border. The RV carries a long smooth bar along the internal part of the dorsal margin, bordered by two pronounced teeth. The LV has a middle ventral snap-pit. Dimension: $\mathrm{L}=0,50-$ $0,76 \mathrm{~mm}, \mathrm{H}=0,29-0,39 \mathrm{~mm}$, the minimum sizes include juveniles too.

Chronostratigraphical and geographical distribution. The species has been mentioned as a taxon of Pannonian origin (Olteanu, 1989) and has been described from the late Miocene (Pannonian) of the Pannonian Basin (Fruška Gora inselberg, northern Serbia) (Ter Borgh et al., 2013). In the Eastern Paratethys, L. striatocostata has been reported from the Pontian (Adzhiveli section, Azerbaijan) (Van Baak et al., 2016) and upper Aspheronian (Hajigabul section) (Lazarev et al., 2019) of the South Caspian Basin. It is also a common faunal element of middle - upper Quaternary and Holocene deposits from Azerbaijan, Turkmenistan and northern Iran (Mandelstam et al., 1962; Yassini, 1986).

Ecology. The recent living species in the Caspian- and Black Sea have been reported from salinities ranging from 4 - 12,7 \%o (Yassini, 1986; Stancheva, 1989). During the Pannonian, L. striatocostata was mentioned as part of an assemblage that was dominated by brackish to freshwater species inside Lake Pannon.

\section{Amnicythere aff. striatocostata} Fig. $21 \mathrm{j}-\mathrm{n}$

Description. The carapace has an elongated shape in lateral view. The dorsal and the ventral margin run parallel to one another. The ventral margin is depressed medially whereas the hinge margin is almost straight. 

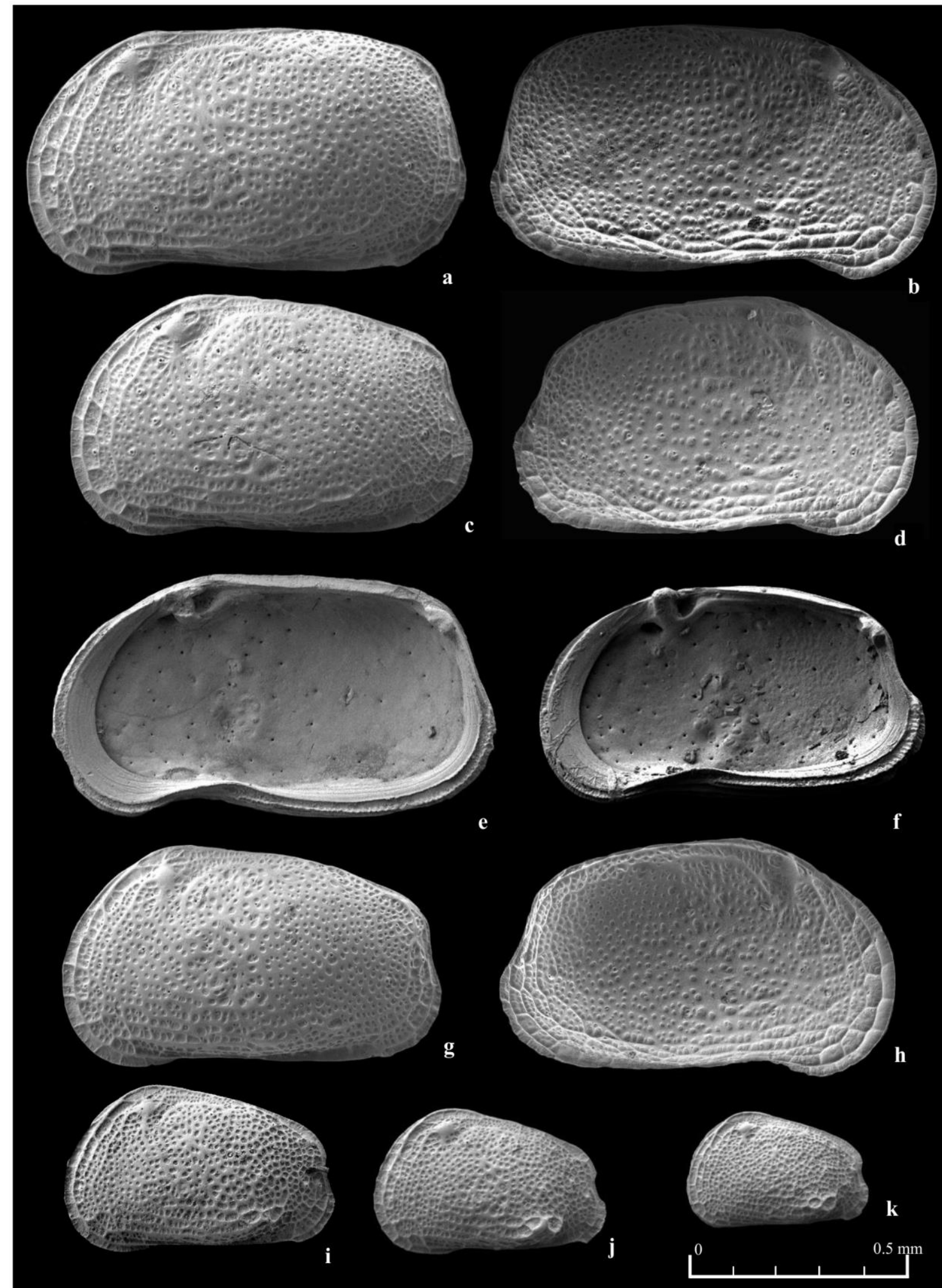

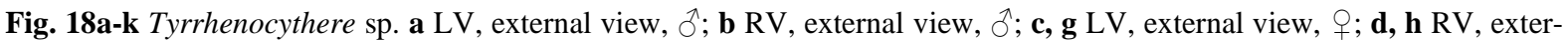
nal view, $\circ$; e RV, internal view, ô; f RV, internal view, $\circ$; i LV, external view, A1 juvenile; $\mathbf{j}$ LV, external view, A2 juvenile; k LV, external view, A3 juvenile; (all specimens from section B, samples $19 \mathrm{~m}$ and $23 \mathrm{~m}$ ). 


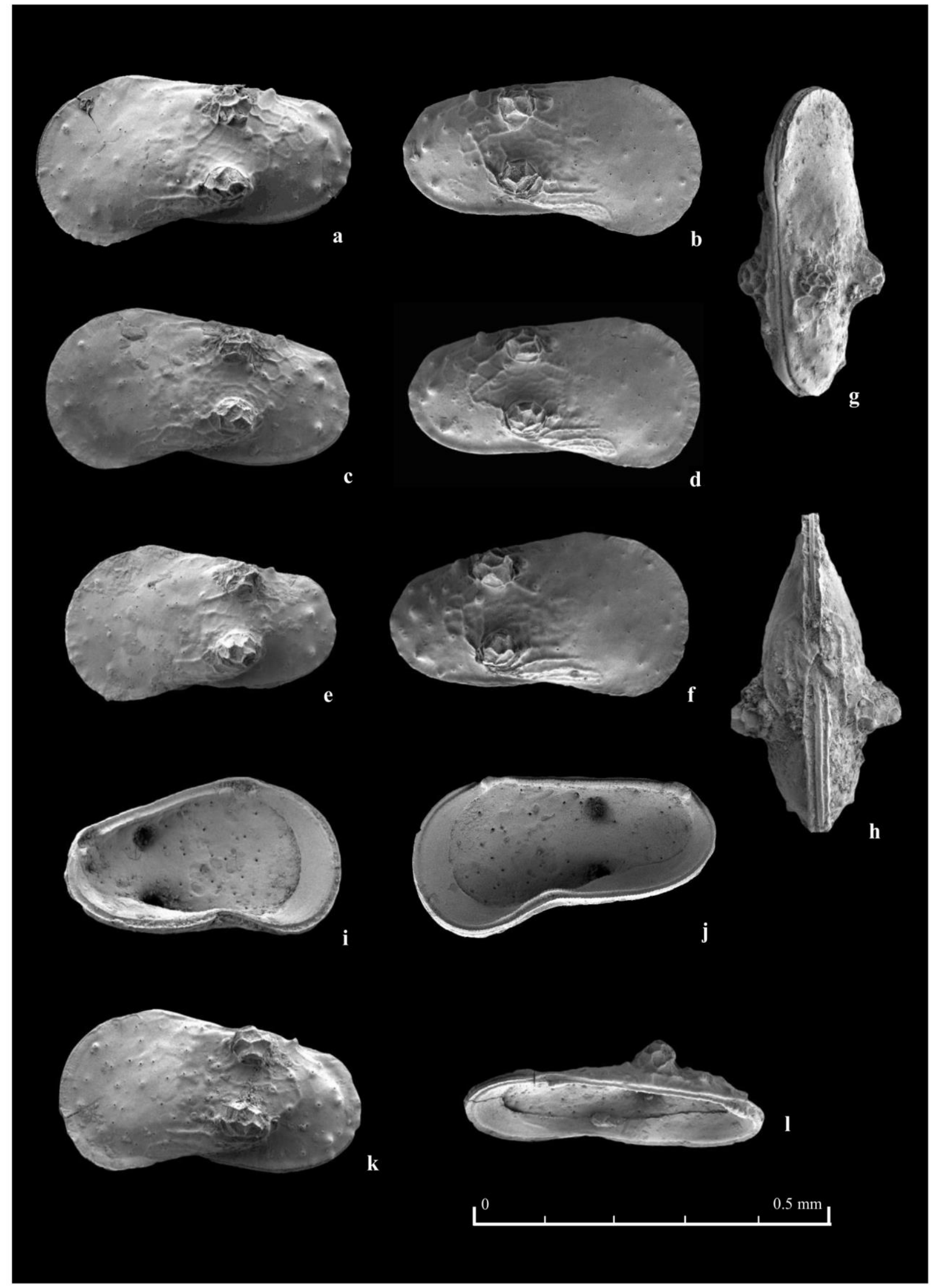

Fig. 19a-l Leptocythere sp. 1; a, c, e, $\mathbf{k}$ LV, external view; b, d, f RV, external view; $\mathbf{g}$ Carapace, dorsal view; $\mathbf{h}$ Carapace, ventral view; i LV, internal view; j RV, internal view; l RV, dorsal view; (all specimens from section A, samples $0 \mathrm{~m}-35,5 \mathrm{~m}$ ). 


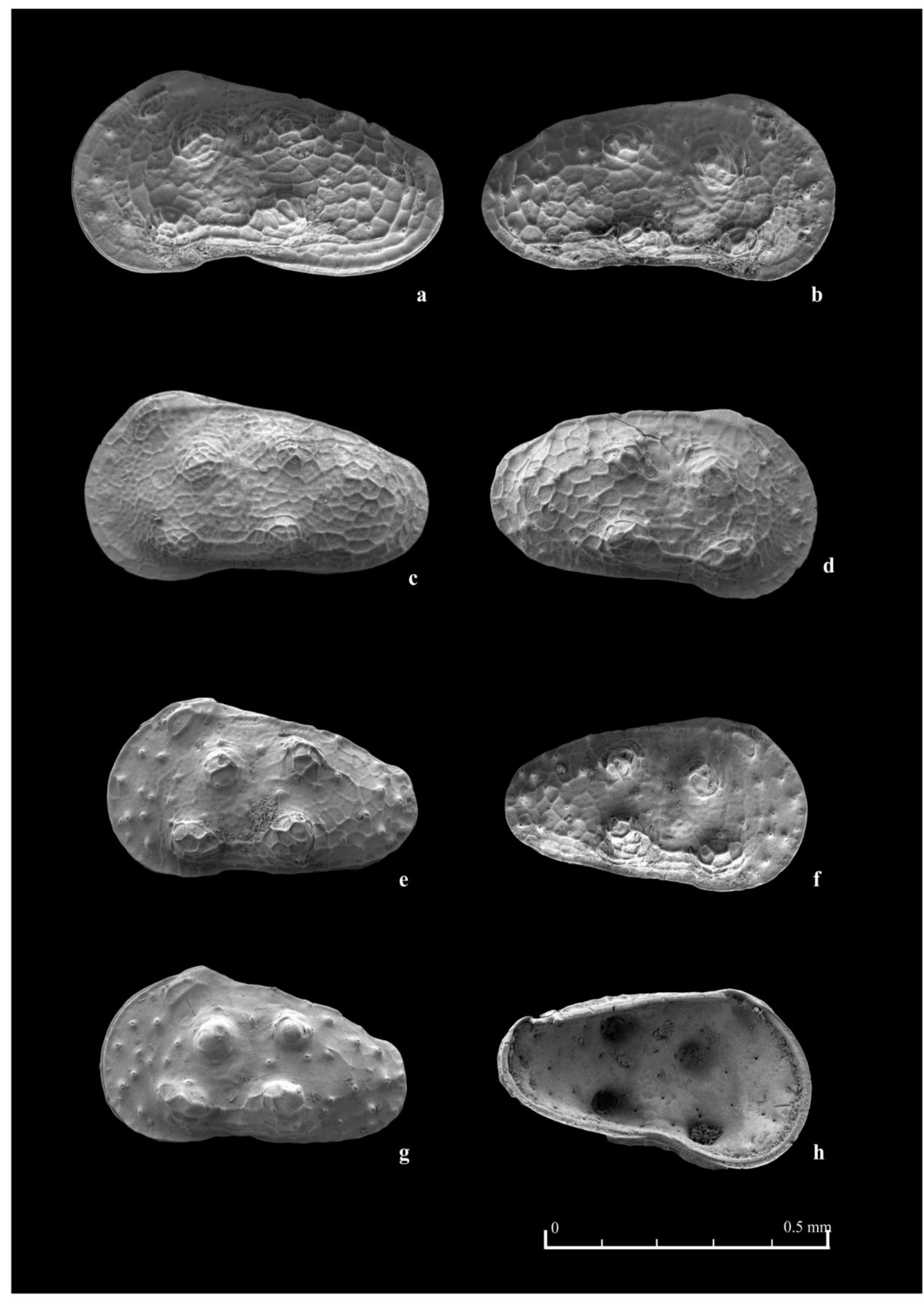

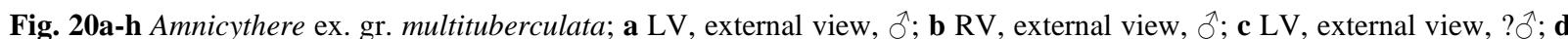
RV, external view, o; e, g LV, external view, ? A1 juveniles; f RV, external view, ?A1 juvenile; h LV, internal view, ?A1 juvenile; (all specimens from section A, samples $0 \mathrm{~m}-35,5 \mathrm{~m}$ ). 

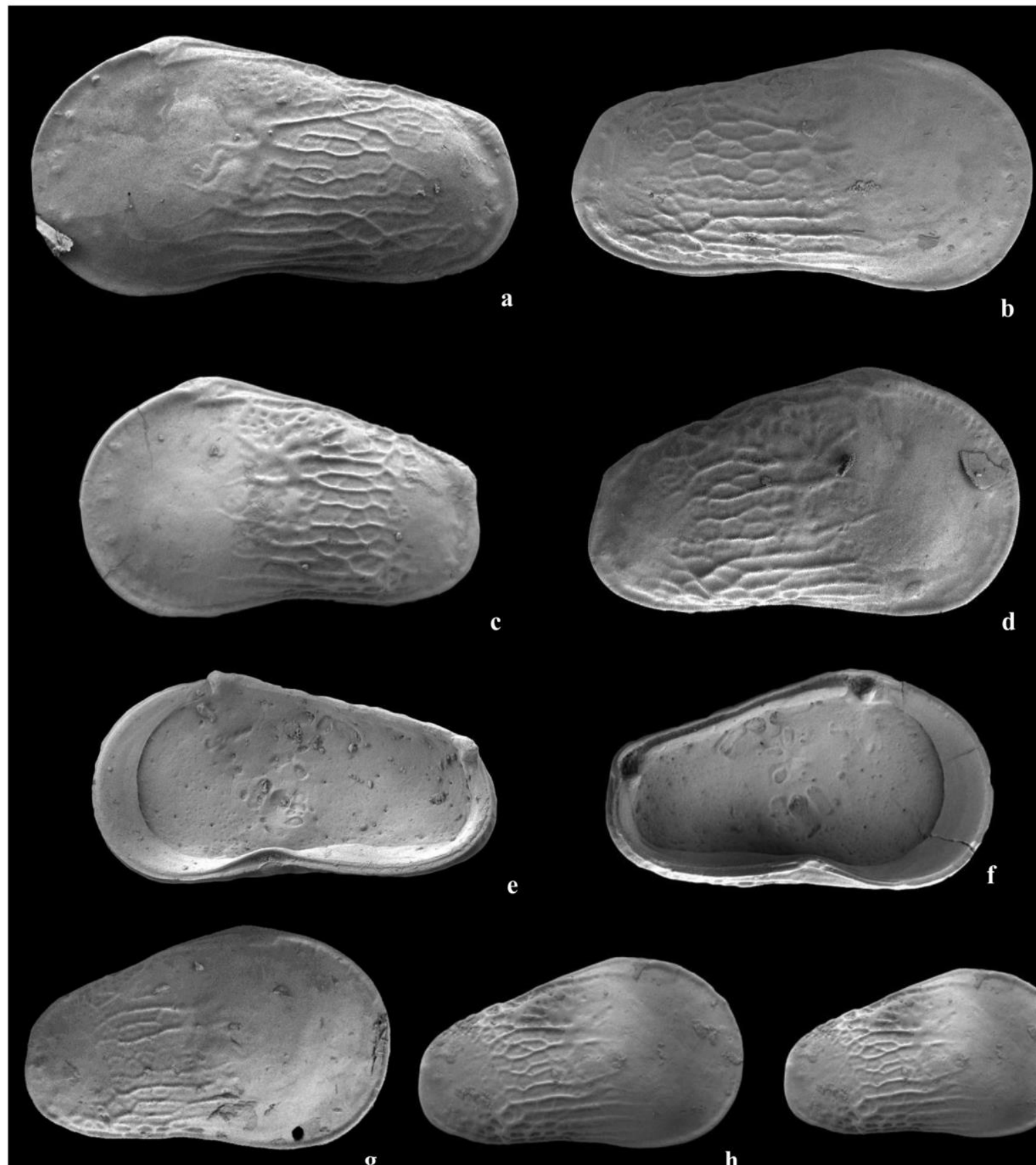

e

g

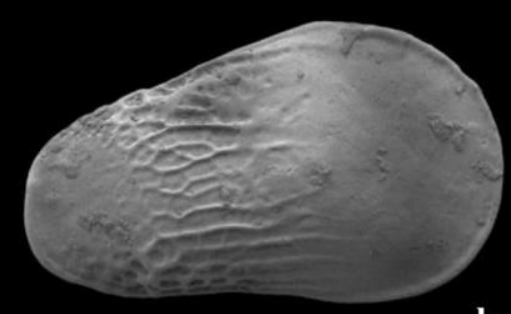

h
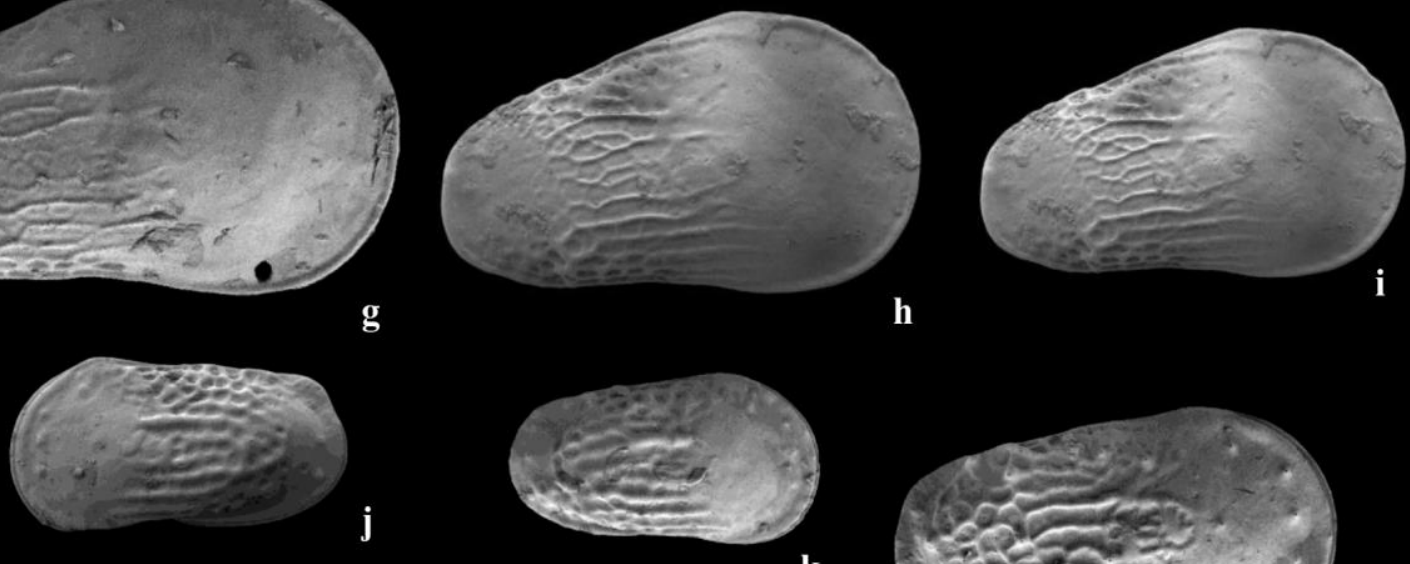

$\mathbf{k}$
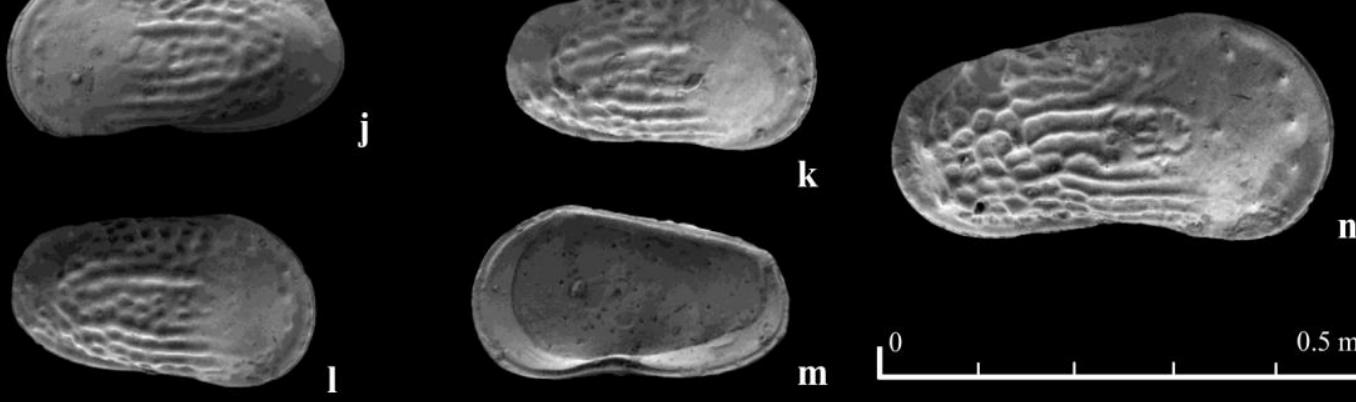

$0.5 \mathrm{~mm}$

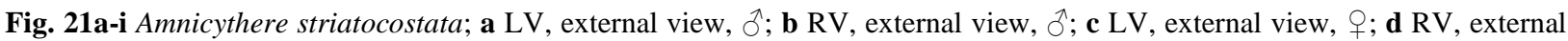
view,, ; e RV, internal view,, ; f LV, internal view, $\circ$; g RV, external view, A1 juvenile; h RV, external view, A2 juvenile; i $\mathrm{RV}$, external view, A3 juvenile; j-n Amnicythere aff. striatocostata; j LV, external view, ? $\odot$; k, $\mathbf{l}$ RV, external view, $\bigcirc ; \mathbf{m}$ RV, internal view, ? $\odot$; n. RV, external view, ? $\hat{O}^{\lambda}$; (all specimens from section A, samples $0 \mathrm{~m}-35,5 \mathrm{~m}$ ). 
The transition onto the slightly rounded posterior end is obtuse and in the posterodorsal area a hinge ear can appear more or less pronounced. The margin is slightly compressed and, in any case, appears less rounded than the anterior end. The anterior-and the posterior boarder lack any ornamentation but occasionally contain rare conulus. In the center of the valve weakly pronounced longitudinal running ribs are present that are covered by a deep reticulated pattern that covers almost the entire horizontal width of the carapace. The inner lamella is widely pronounced and the hinge and muscle scar are typical of this genus. Dimension: $\mathrm{L}=0,32-0,45 \mathrm{~mm}, \mathrm{H}=0,17-$ $0,22 \mathrm{~mm}$, the minimum sizes include juveniles too.

Remarks. This species shows clear resemblance to $A$. striatocostata but is much smaller. Also, the general outline is more subrectangular. The parallel running ribs are somewhat concentrated in the central part of the valve and the ornamentation between them consists mainly of deeper rounded, polygonal pits. A morphologically similar species has been described by Olteanu $(1995,1998)$ under the name Euxinocythere schweyeri from the Pontian and Dacian deposits of the Dacian Basin. The species however has a less pronounced ornamentation pattern.

\section{Amnicythere sp. 1}

Fig. 22a-n

Description. The carpace is elongated in lateral view and uniformly covered with a pitted pattern that is more or less fine pronounced. The dorsal margin runs straight and continues smoothly onto the broadly rounded anterior end. The ventral margin is slightly concave at mid-length. The anterior border is well rounded and the posterior end slightly narrower and mid-posteriorly more angular. The entire surface is uniformly covered with fine to medium sized pits that sometimes have the tendency to be arranged in polygonal nets that further developed a weakly pronounced secondary recticulated ornamentation. In the coarser ornamented specimens, a short ridge can be observed running in the median area of the valve. In the finer pitted specimens, the ridge is thinner and usually accompanied by other parallel or concentric ridges. Along the anterior border 3-4 conules pores are displayed. The inner lamella is well developed, both anteriorly and posteriorly, extending also along the ventral margin. On the RV, the hinge is pronounced as a long, thin and smooth bar with two elongated, slightly divided teeth at both ends. Some specimens are noticeably shorter (k-n) and have, apart from the same ornamentation pattern, 2-3 postero-ventral tubercles that are not covered by ornamentation. We interpret this as sexual dimorphism and we consider these female specimens. Dimension: $\mathrm{L}=$ $0,46-0,63 \mathrm{~mm}, \mathrm{H}=0,22-0,28 \mathrm{~mm}$, the minimum sizes include juveniles too.

Remarks. This species shows a highly variable ornamentation. The shape and general aspects of the valves surface resemble those described of Amnicythere oforta (Livental) (in Agalorova et al., 1961). The original handdrawing however is not accurate enough and a closer determination was not made possible. Similar other forms including Leptocythere nata Markova (in Yassini, 1986), Amnicythere polymorpha (Olteanu, 1989) and Amnicythere aff. ebersini Scheidaeva, show similarities but due to the high variation in ornamentation it is difficult to assign the present species to either one of them.

\section{Amnicythere sp. 2 \\ Fig. 24i-q}

Description. This species has an elongated carapace with a much wider and flattened anterior end in comparison to the posterior one. The dorsal margin is straight and pointed towards the posterior. The ventral margin shows a clear concavity at mid-length. The ornamentation is weakly pronounced and varies from finely pitted to areas that bear a reticulated pattern, mainly concentrated in the median region and posterior parts. Within the anterior half of the valve any kind of ornamentation is almost absent. In the postero - ventral part a more or less visible tubercula can be noticed that we interpret to be related to the sexual dimorphism. Medium sized conulus pores are present along the anterior-and posterior margins. The inner lamella is moderately developed in the anterior part and narrower along the posterior boarder. The hinge on the RV valve shows a long thin smooth median bar with two elongated, subdivided teeth at both ends. Dimension: $\mathrm{L}=0,49-0,54 \mathrm{~mm}, \mathrm{H}=0,25-0,29 \mathrm{~mm}$, the minimum sizes include juveniles too.

\section{Amnicythere sp. 3 \\ Fig. 23a-h}

Description. This species is characterised by a small sized carapace (less than $0,5 \mathrm{~mm}$ ) and an ornated, quite regular appearing polygonal ornamentation network. The maximum height is located in the anterior half, close to the cardinal angle. The dorsal margin runs straight and is passing onto the rounded anterior end at an obtuse angle. The posterior-and the anterior boarders pass smoothly onto the medially concave ventral margin. The valves surface is covered with medium-sized meshes of almost equal size. Occasionally, inside the main polygons a secondary net structure occurs. Close to the mid-dorsal area an ornamentation net structure radiates and forms one or two irregular subcentral tubercula. The inner lamella is well developed anterior and posterior, and along the ventral margin. A snap-pit is present on the concavity on the internal part of the RV. The hinge on the RV is made of a smooth median bar and elongated, divided teeth at the ends. Dimension: $\mathrm{L}=0,40-0,52 \mathrm{~mm}, \mathrm{H}=0,22-0,27$ $\mathrm{mm}$, the minimum sizes include juveniles too.

\section{Amnicythere sp. 4}

Fig. 23i-o

Description. This species has a similar shape to A. sp. 3, but is slightly more elongated and narrower. The valve surface is covered by a similar but broader sized polygonal pattern. Secondary ornamentation is absent and the crests that separate the polygons appear thinner and sharper than in A. sp. 3. Conules pores are high and distributed randomly. A small spine is present, located close to the dorso-posterior margin. The anterior margin is broadly rounded and much higher than the posterior one. 


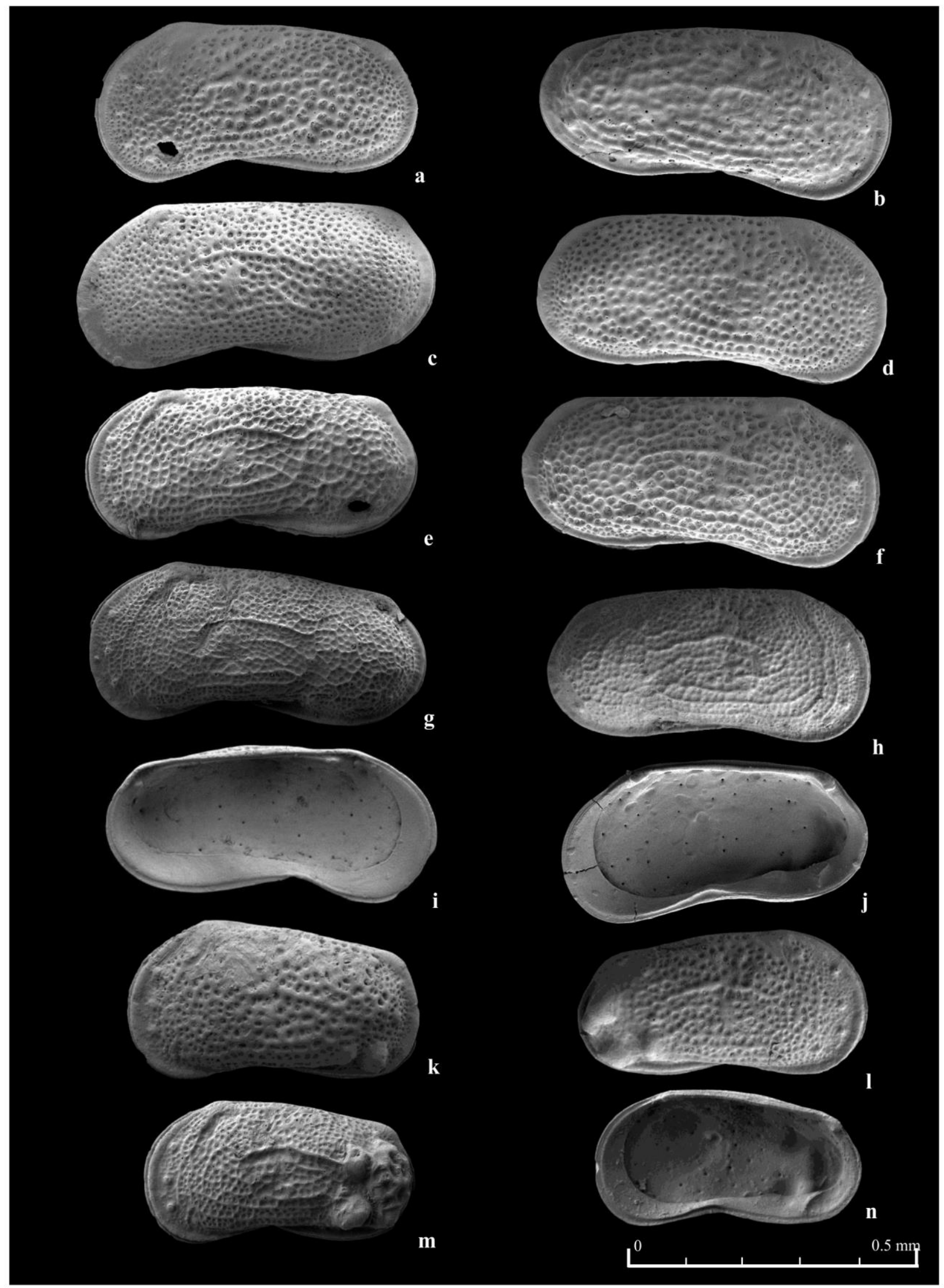

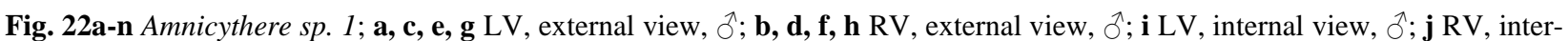

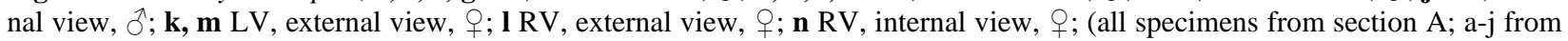
sample 35,5 m; k-n from sample $32 \mathrm{~m}$ ). 


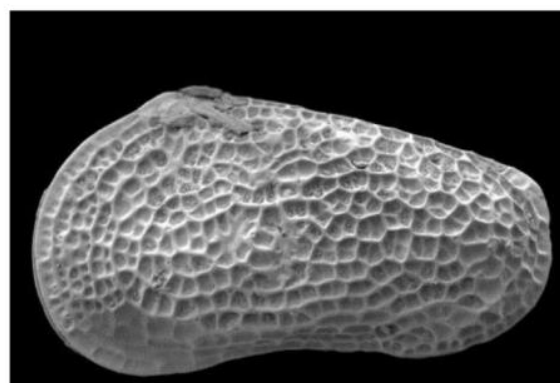

$\mathbf{a}$

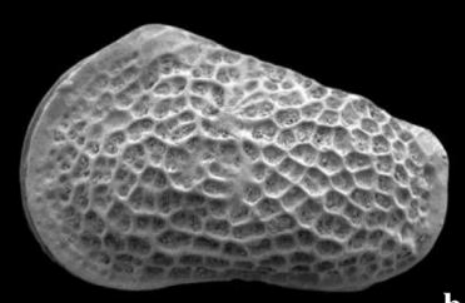

b
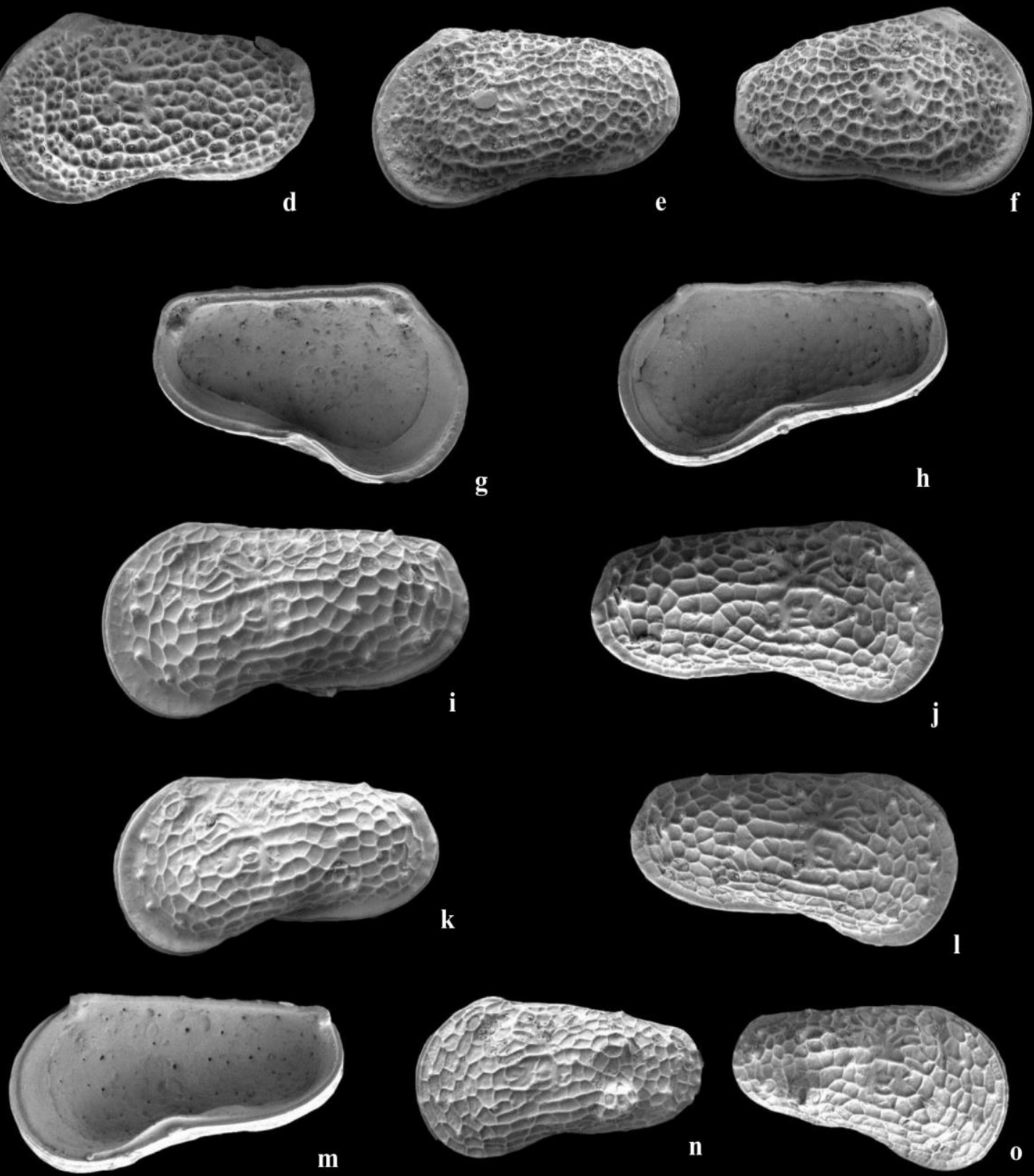

$0.5 \mathrm{~mm}$

Fig. 23a-h Amnicythere sp.3; a LV, external view, ô; b, d, e LV, external view, $q$; c, f RV, external view, ${ }^{\prime}$; g LV, internal

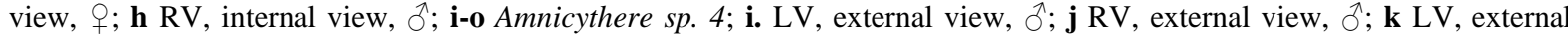

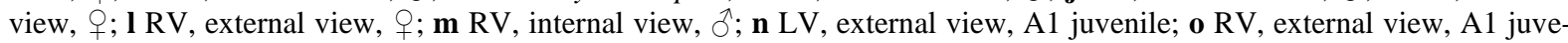
nile; (all specimens from section A, samples $0 \mathrm{~m}-35,5 \mathrm{~m}$ ). 
Juvenile specimens have two tubercula in the posterior half of the valve. The hinge on the RV is made of a smooth median bar and elongated, divided teeth at the ends. A knot is present in the median area of the ventral margin. The inner lamella is well developed anterior- and posterior and continues along the ventral margin. Dimension: $\mathrm{L}=0,44-0,47 \mathrm{~mm}, \mathrm{H}=0,21-0,24 \mathrm{~mm}$, the minimum sizes include juveniles too.

\section{Euxinocythere (Maeotocythere) bosqueti \\ (Livental, 1929)}

Fig. 24a-h

1929 Cythere bosqueti nov. sp.- Livental, p. 24, pl. 1, fig. 27.

1962 Leptocythere bosqueti (Livental)- Mandelstam et al., p. 225, pl. 36, fig. 8-10.

1978 Leptocythere bosqueti (Livental)- Olteanu, p. 1019 , pl. 4. fig. 2, pl. 6, fig. 6, pl. 7, fig. 11.

1990 Leptocythere bosqueti (Livental)- Sokač, p. 687, pl. VIII, fig. 12.

1989 Leptocythere (Maeotocythere) bosqueti (Livental)Olteanu, p. 736, pl. V, fig. 5-6.

1998 Euxinocythere bosqueti (Livental)- Olteanu, pl. VI, fig. 5.

2011 Leptocythere bosqueti (Livental)- Olteanu, p. 175, pl. XXVI, fig. 7.

Description. The carapace has a subovate to rectangular shape in lateral view and a strongly sculptured surface. The dorsal margin is almost straight, passing in an obtuse angle onto the posterior-and the anterior end. The anterior angle is more obtuse and the hinge margin, in some cases, extends onto the anterior border. Both the anterior and the posterior ends are smoothly passing onto the medially slightly concave ventral margin. The sculpture consists of randomly and interlacing high plications, the transversal ones being more pronounced. The species has a clear arcuate posterior crest. Another one is running more or less parallel to the anterior margin before finally reaching the antero-dorsal cardinal angle. The hinge is well developed and amphidont, with a crenulated bar that bears enlarged toothlets anteriorly- and posteriorly. A snap-pit is present in the concavity located in the middle of the ventral margin. The inner lamella is well developed, both in the anterior-and posterior ends and continues along the ventral margin. Dimension: $\mathrm{L}=0,53-0,58 \mathrm{~mm}, \mathrm{H}=$ $0,30-0,32 \mathrm{~mm}$, the minimum sizes include juveniles too. Chronostratigraphical and geographical distribution. Inside the Central Paratethys this species is described from the Pontian deposits of the Eastern area of the Pannonian Basin (Bulgaria and Yugoslavia), the Dacian Basin (Sokač, 1990; Olteanu, 1989; Olteanu, 2011; Stoica et al., 2013) and the Pontian of the Bădislava - Topolog area of Romania (Floroiu et al., 2011). In the Eastern Paratethys it is known from the late Pliocene (Pontian, Apsheronian) of the southern parts of Azerbaijan (Van Baak et al., 2013, 2016) Turkmenistan and the north Caucasus region (Sokač, 1990). This species is also found among recent faunal assemblages of the Caspian Sea (O1teanu, 1978, Yassini, 1986).
Ecology. Recent living representatives of this species have been reported from mesohaline environments (12 $13 \%$ ) in the Caspian Sea (Yassini, 1986).

Superfamily Cytheroidea Baird, 1850

Genus Loxoconcha Sars, 1866

Loxoconcha babazananica (Livental, 1929) Fig. 25a-k

1929 Loxoconcha Babazananica nov. sp- Livental, p. 35, pl. 1, fig. 44-45.

1949 Loxoconcha babazananica Liv.- Schweyer, p. 48, pl. VI, fig. 2.

1956 Loxoconcha babazananica Livental- Suzin, p. 67, pl. VI, fig. 8.

2013 Loxoconcha babazananica Livental- Stoica et al., p. 140 , pl. 2, fig. 38 .

2013 Loxoconcha babazananica Livental- Van Baak et al., p. 124, fig. 4b, 24.

2016 Loxoconcha babazananica Livental- Van Baak et al., p. 603, fig. 8a, 10-13.

Description. The small quadrate and narrowed posteriorly carapace, is covered with a coarsely reticulated to pitted sculpture that becomes finer and smoother towards the marginal area. The species appears rather inflated in the posterior half and bears a distinguishable eye-spot in the anterodorsal corner. The dorsal margin is almost straight with a discreet concavity in the posterior segment. The dorsal margin passes smoothly onto the broadly rounded anterior end at an obtuse angle and onto the narrower rounded posterior end at a less obtuse angle. The ventral margin is slightly convex arcuate and recurving towards the posterior end. The extent of the degree of ornamentation varies between individual specimens. In some cases, the reticulated ornamentation in the posterior end is replaced by weakly pronounced meshes. The internal view reveals the presence of a central muscle scar that is arranged in a vertical row of four adductor scars and a vshaped frontal scar. The hinge is well developed and amphidont, with a strongly crenulated bar and two strongly pronounced toothlets in the anterior- and posterior area of the LV. Dimension: $\mathrm{L}=0,41-0,59 \mathrm{~mm}, \mathrm{H}=0,26-0,36$ $\mathrm{mm}$, the minimum sizes include juveniles too.

Chronostratigraphical and geographical distribution. The species is known from saline - brackish water deposits from the Pliocene - Pleistocene (Babazanan, Lokbatan, Goychay, Hajigabul - Akchagylian, Apsheronian and Bakunian) of the South Caspian Basin (Azerbajian) (Livental, 1929; Van Baak et al., 2013; Lazarev et al., 2019), the middle Romanian (Pelendavian) of the Slănicul de Buzău section of the Dacian Basin (Van Baak et al., 2015), the upper Pontian of the Ramnicu Sarat and Badislava - Topolog area (South Carpathian Foredeep, Romania) (Floroiu et al., 2011; Stoica et al., 2013) and is generally widespread from late Miocene to recent throughout the Black -and Caspian Sea region (Van Baak et al., 2015). L. babazananica, in many papers considered as Loxoconcha immodulata Stepanaitys (Boomer et al., 1996, 2010), is further described from Plio-Pleistocene 


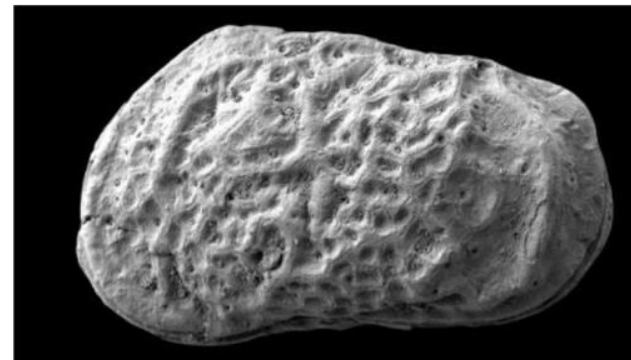

$\mathbf{a}$

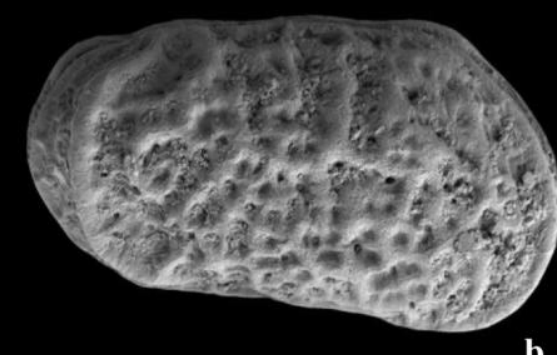

b

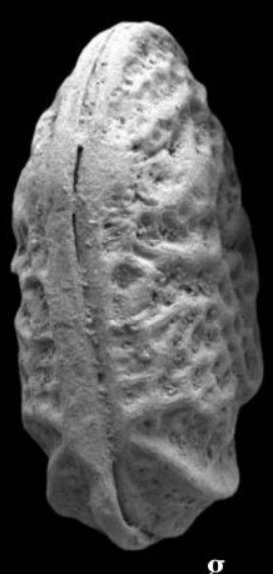

g

C
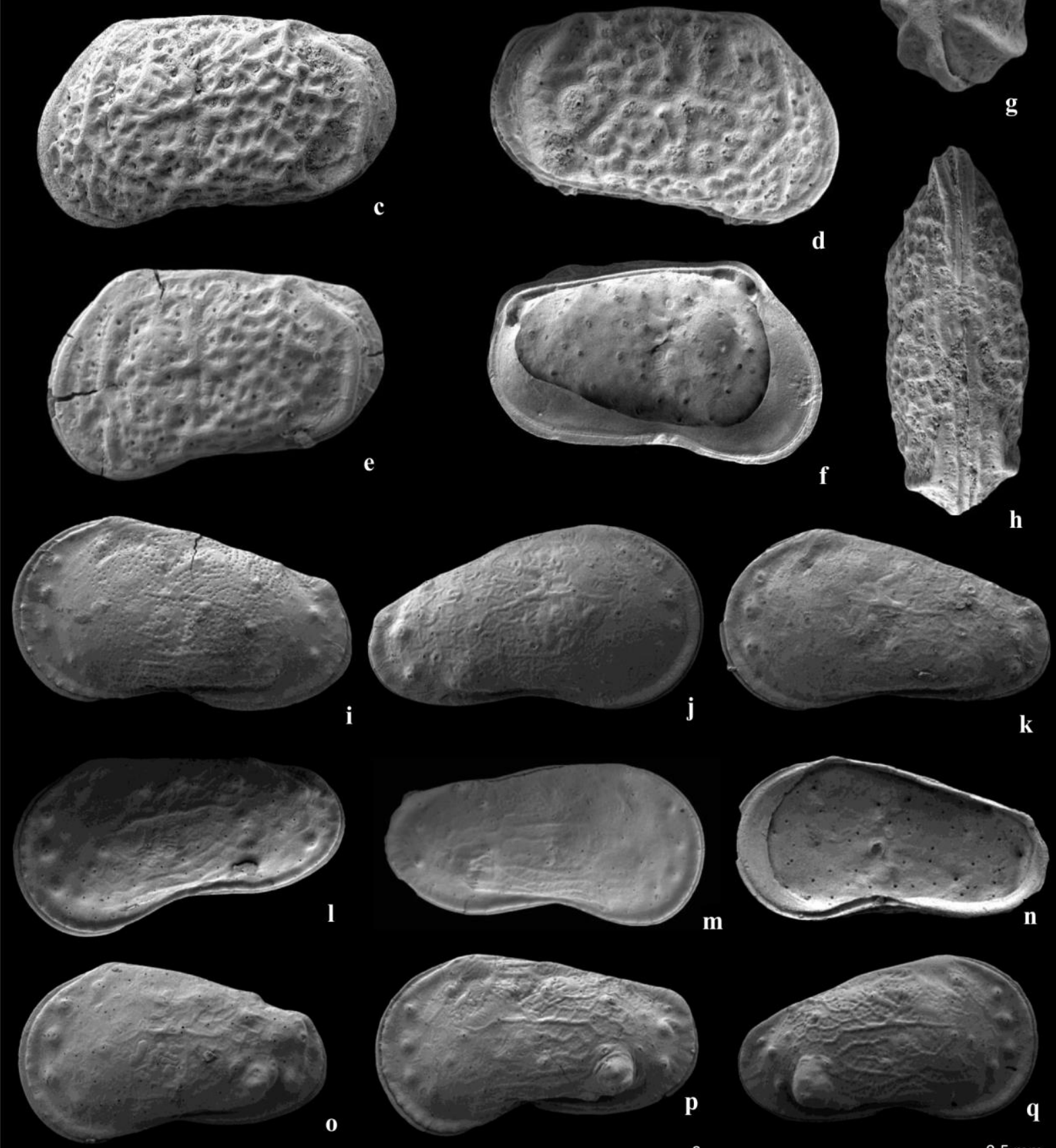

m
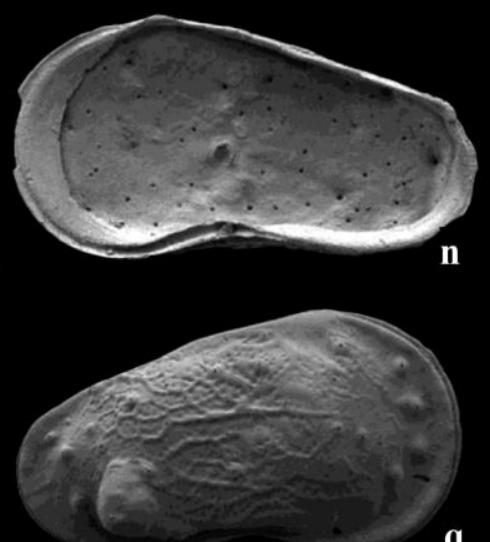

Fig. 24a-h Euxinocythere (Maeotocythere) bosqueti; a, c LV, external view, ô; b RV, external view, ô; d RV, external view,

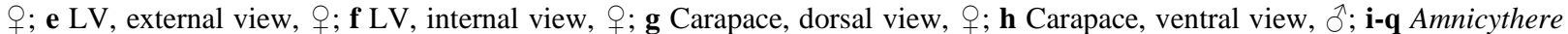

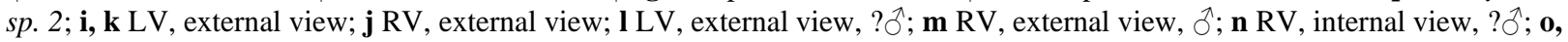
p LV, external view; q RV, external view; (all specimens from section B; a-h from sample $69 \mathrm{~m}$; i-q from sample 30,5 m). 

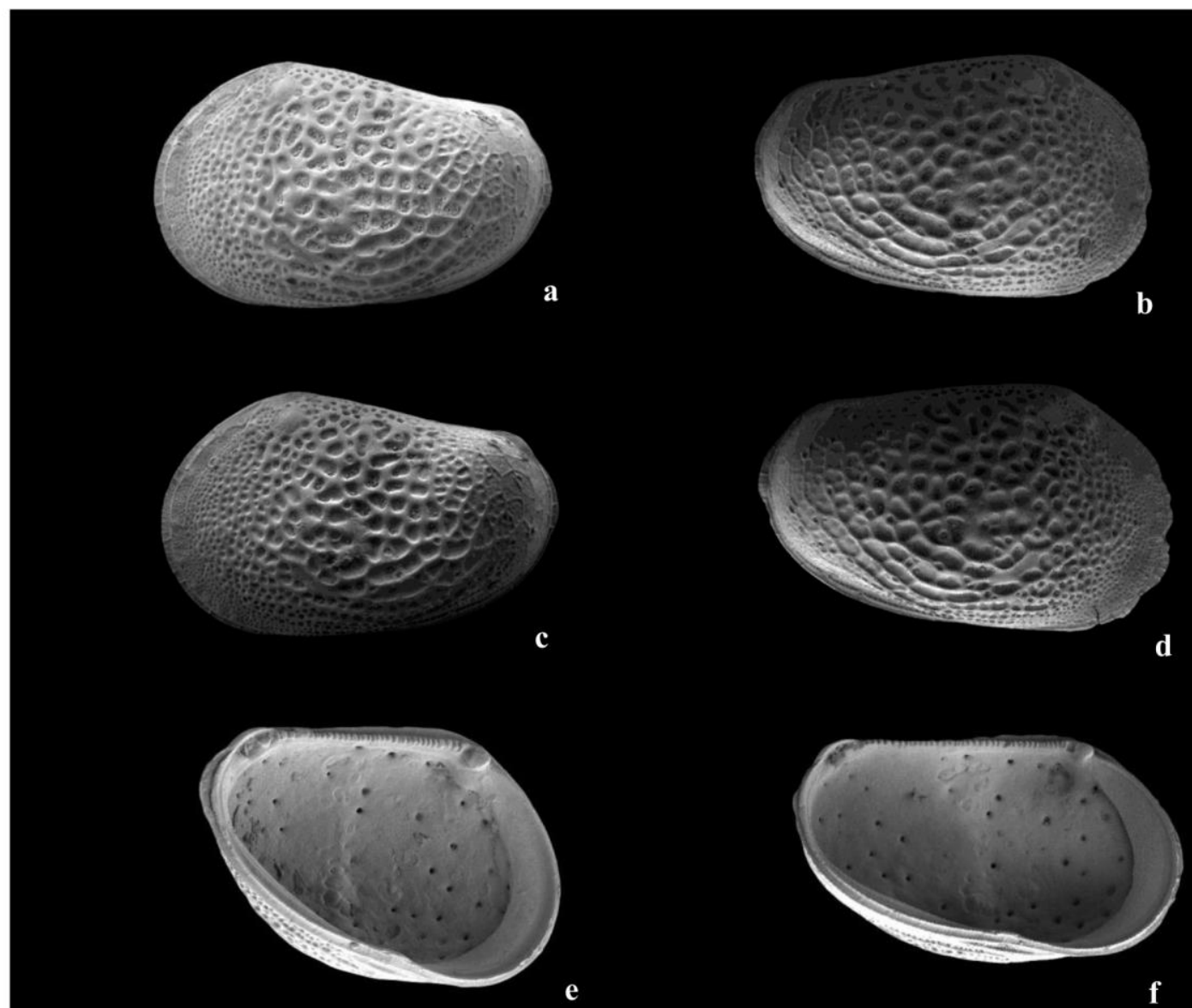

e
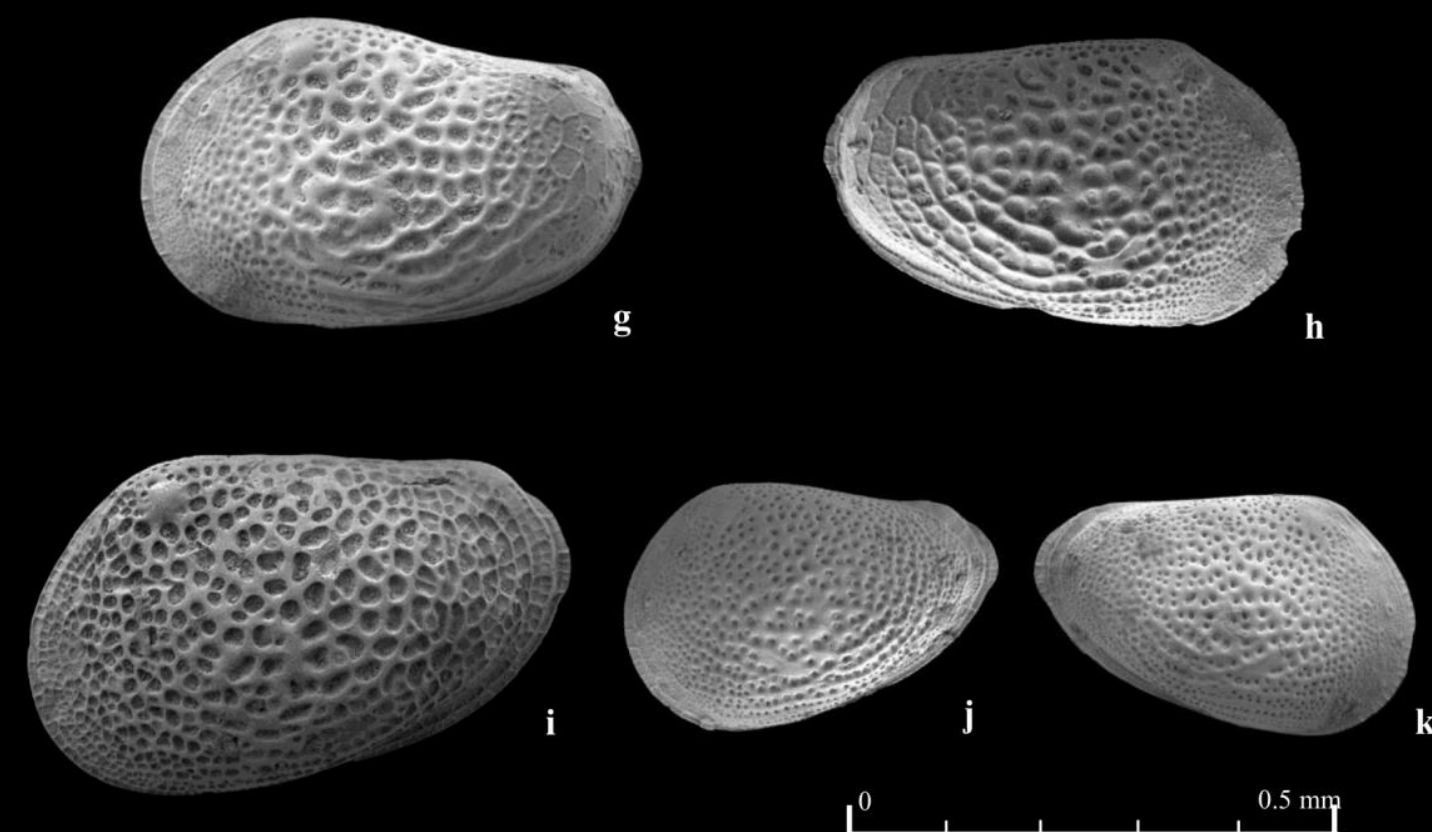

$0.5 \mathrm{~mm}$

Fig. 25a-k Loxoconcha babazananica; a, c, g, i LV, external view; b, d, h RV, external view; e, f LV, internal view; j LV, external view, A1 juvenile; k RV, external view, A1 juvenile; (all specimens from section A, samples 0 m - 35,5 m). 
deposits of Turkmenistan, the Aral Sea and from recent brackish-water assemblages of the Caspian Sea (Boomer et al., 1996, 2005, 2010). Faranda et al. (2007) placed $L$. immodulata in the extinct genus Loxoconchissa (Loxocaspia).

Ecology. The living specimens of L. babazananica inhabit sublittoral environments of the Caspian Sea.

\section{Loxoconcha ex. gr. eichwaldi (Livental, 1929)} Fig. 26a-k

1929 Loxoconcha Eichwaldii nov. sp.- Livental, p. 34, pl. 1 , figs. 42,43 .

1961 Loxoconcha eichwaldi Livental- Agalarova et al., p. 141 , pl. 79, figs. $4 a-b$.

1967 Loxoconcha eichwaldi Livental- Agalarova, pl. 20, figs. 3a,b.

1978 Loxoconcha eichwaldii Livental- Carbonnel, p. 114, pl. 1, fig. 4.

1999 Loxoconcha eichwaldi Livental- Gliozzi, p. 198, pl. 1, fig. d.

2007 Loxoconcha eichwaldi Livental- Faranda et al., p. 306, fig. 3, 3-4.

2016 Loxoconcha eichwaldi Livental- Stoica et al., p. 865, pl. 6, fig. 10-14.

2016 Loxoconcha eichwaldi Livental- Van Baak et al., p. 67, fig. 4a, 13, 14.

Description. The carapace is oval to rhomboidal in shape and has a distinct punctuate pattern, varying sligthly in size but generally becoming finer towards the marginal area. Like many other species of this genus, $L$. ex. gr. eichwaldi has a distinguishable eye-spot in the dorsoanterior corner. The dorsal margin is straight and passes smoothly onto the broadly rounded anterior margin. At the posterior end, especially visible in the RV of females, the dorsal margin passes in an obtuse angle onto the posterior boarder, forming a weakly pronounced ledge. The otherwise rounded posterior is inflated and wider than the anterior end, especially in males. The inner lamella is well developed and contains several simple marginal pore canals. The central muscle scar consists of a vertical row of four adductor scars and a V-shaped frontal scar. The hinge is amphidont and made of a crenulated bar that has two separated posterior teeth and one at the anterior end on the RV. Dimension: $\mathrm{L}=0,57-0,68 \mathrm{~mm}, \mathrm{H}=0,34-$ $0,43 \mathrm{~mm}$, the minimum sizes include juveniles too.

Chronostratigraphical and geographical distribution. The species has been reported from several successions in the Eastern Paratethys. It is known from the Pontian to the Akchagylian - Bakunian interval of Azerbaijan, Turkmenistan, Crimea, Caucasus, Moldavia (Agalarova et al., 1961; Agalarova 1967; Van Baak et al., 2016; Lazarev et al., 2019) and the Pontian of the Zheleznyi Rog section in Russia (Stoica et al., 2016). In the Central Paratethys it has been described from the Pannonian and Pontian of Serbia (Krstić, 1972) and the Pontian of Bosnia (Sokač, 1967). Outside the Paratethys it has been mentioned from the late Miocene of Corsica, Italy, the Pliocene of the Rhone Valley (Carbonnel, 1978) and the Messinian of the Vicenne Basin in the central Apennines in Italy (Gliozzi, 1999). L. eichwaldi has further been described from the Pontian of the Eastern Black Sea region in Turkey (Tunoğlu, 2001).

Ecology. Together with Loxoconcha muelleri (Méhes) and Cyprideis agrigentina Decima, L. eichwaldi has been described from low mesohaline environments (Grossi et al., 2015). Recent living Loxoconcha species are reported from mesohaline to euryhaline waters worldwide (Gliozzi, 1999). Some forms are occurring in stenohaline environments and are limited to marine littoral habitats (Loxoconcha multifora (Norman)). Others have euryhaline distributions (Loxoconcha rhomboidea (Fischer) (Neale, 1988)).

\section{Loxoconcha muelleri (Méhes, 1908)}

Fig. 27a-g

1908 Cythereis mülleri n. sp.- Méhes, p. 563, pl. 9, fig. 1-4, fig. 8, fig. 15-18.

1985 Loxoconcha muelleri (Méhes)- Jiříček, p. 403, pl. 55, fig. 10-13.

2016 Loxoconcha muelleri (Méhes)- Stoica et al., p. 865 , pl. 6, fig. $1-9$.

Description. The carapace has an oval rhomboidal shape in lateral view. The female carapace is slightly oblique to oval rhomboidal in shape, high, compressed and the ventral and dorsal margin run almost parallel to each other. The male carapace is slightly more elongated and has an extended dorsal margin. The straight running dorsal margin passes smoothly onto the broadly rounded anterior end that continues smoothly onto the slightly convex and arcuate ventral margin. The ventral margin is recurving towards the posterior end that, in the posteroventral area of females, shows a slight inflation. Unlike $L$. ex. gr. eichwaldi the surface of this species is less and irregularly pitted. The inner lamella is well developed along the posterior-and anterior margin and the amphidont hinge is represented by a crenulated bar bearing teeth at each end of the LV, whereas at the RV two distinct tooth sockets are observed. Dimension: $\mathrm{L}=0,64-0,66 \mathrm{~mm}, \mathrm{H}=0,39$ $-0,44 \mathrm{~mm}$, the minimum sizes include juveniles too.

Chronostratigraphical and geographical distribution. L. muelleri has been described in the fossil record from the lower Pannonian (Zone A-E/E 3) of Hungary, the Vienna Basin of Austria and Slovakia (Méhes, 1908; Jiříček, 1985) as well as in the Black Sea basin, the Maeotian of the Dacian Basin (Stoica et al., 2016; Lazarev et al., 2020 (submitted)). It has further been described outside the Paratethys domain from the latest Miocene of the Mediterranean of Greece, Crete, France and Spain (Faranda et al., 2007; Gliozzi et al., 2007; Stoica et al., 2016).

Ecology. L. muelleri inhabits shallow brackish water environments and can be found with L. eichwaldi Livental and $C$. agrigentina Decima ("Cyprideis-Loxoconcha assemblage") in low mesohaline habitats (Grossi et al., 2015).

\section{Loxoconcha aff. muelleri (Méhes, 1908)} Fig. 27h-i

Description. This species has a similar outline as $L$. muelleri but displays a different kind of ornamentation pattern. It varies from being rather smooth to containing 

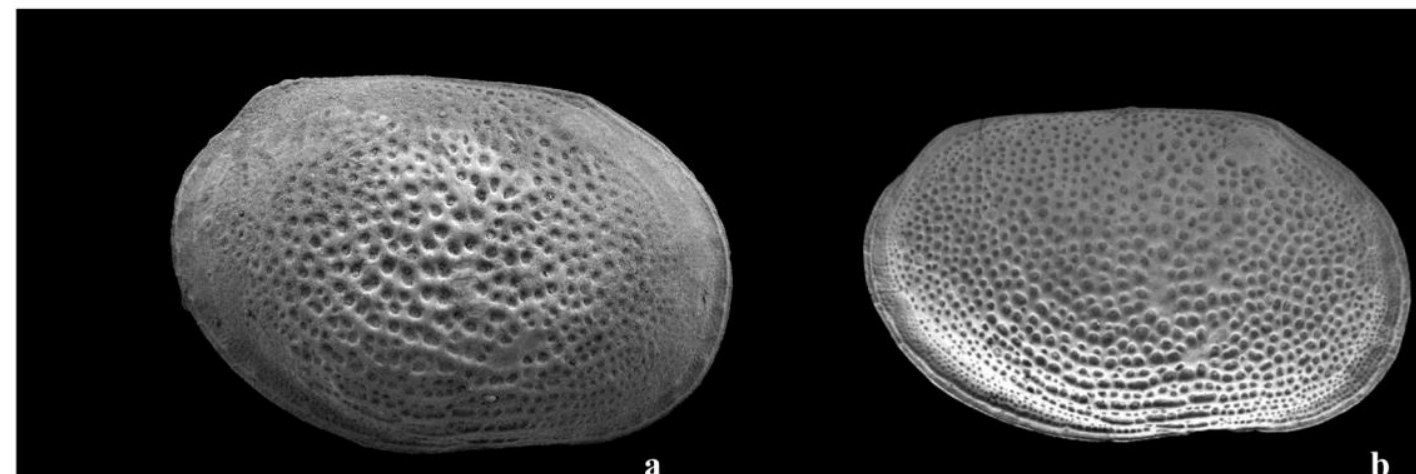

$\mathbf{a}$
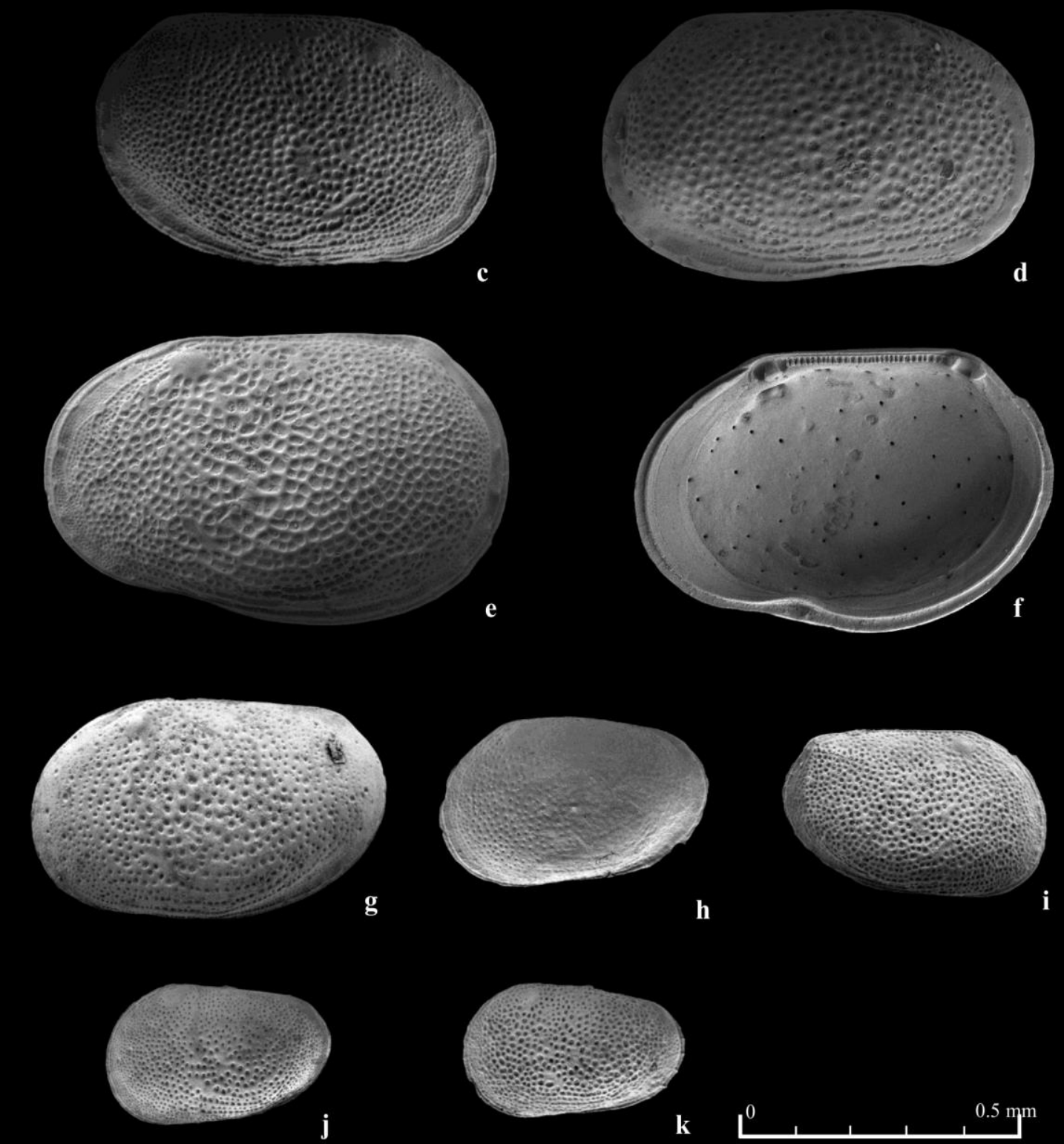

$\mathbf{k}$

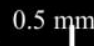

Fig. 26a-k Loxoconcha ex. gr. eichwaldi; a-d RV, external view, ${ }_{+}$; e LV, external view, ơ ; f RV, internal view, ${ }^{\circ}$; g LV, external view, A1 juvenile; h LV, external view, A2 juvenile; i RV, extermal view, A2 juvenile; j, $\mathbf{k}$ LV, external view, A3 juvenile; (all specimens from section B, samples $2 \mathrm{~m}, 19 \mathrm{~m}$ and $23 \mathrm{~m}$ ). 


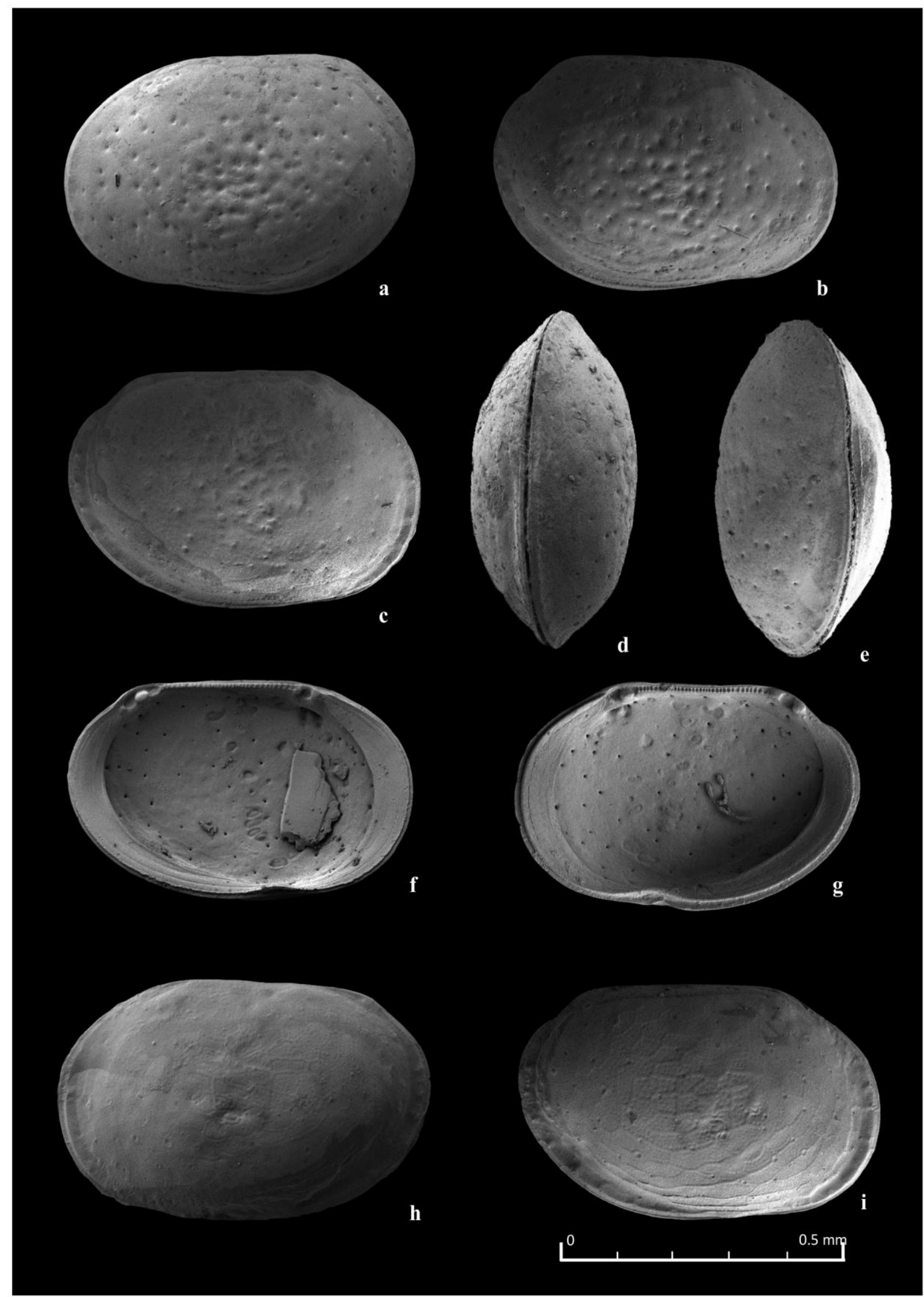

Fig. 27a-g Loxoconcha muelleri; a LV, external view,, ; b, c RV, external view, $\odot$; d Carapace, dorsal view,, ; e Carapace, ventral view,, ; f LV, internal view, + ; g RV, internal view,, ; h, i Loxoconcha aff. muelleri; h LV, external view, + ; i RV, external view, ; (all specimens from section A; a-g from sample $2 \mathrm{~m}, 19 \mathrm{~m}$ and $23 \mathrm{~m}$; specimens h-I from sample $14 \mathrm{~m}$ ). 
weakly pronounced elongated meshes that are concentrated in the median area of the valve and runs weakly pronounced towards the ventral margin. Additionally, random distributed pores can be observed. Dimension: $\mathrm{L}$ $=0,50-0,53 \mathrm{~mm}, \mathrm{H}=0,30-0,31 \mathrm{~mm}$, the minimum sizes include juveniles too.

Loxoconcha petasa (Livental, 1929) Fig. 28a-j

1929 Loxoconcha petasus nov. sp.- Livental, p.33, pl. 1, fig. 39-41.

1978 Loxoconcha petasa Lievental- Olteanu, pl. 5, fig. 8 ; pl. 7 , fig. 1.

1967 Loxoconcha ex. gr. petasus Livental- Agalarova, p. 110 , pl. 19, fig. 1a.

1972 Loxoconcha petasus Livental- Sokač, p. 86, pl. XLVI, fig. 2-8.

1986 Loxoconcha petasa Livental- Yassini, p. 50, pl. 17, fig. 1-3.

2001 Loxoconcha petasus Livental- Tunoğlu, p. 142, pl. 1, fig. 1-3.

2013 Loxoconcha petasa Livental- Stoica et al., p. 140, pl. 2, fig 37.

2013 Loxoconcha petasa Livental- Van Baak et al., p. 124, fig. 4b, 22.

Description. The carapace is rhomboidal in lateral view and shows a coarse and irregular reticulate surface ornamentation and a distinguishable eye-spot. The ornamentation is composed of meshes of different sizes that tend to be arranged in longitudinal running rows in proximity to the ventral margin. The dorsal margin is straight and is passing smoothly onto the rounded convex anterior border as well as onto the broadly rounded posterior end at a small, rather deep depression that is creating an edge that is especially visible on the RV. Anterior and posterior pass smoothly onto the ventral margin which runs parallel and almost straight to the dorsal margin. Towards the posterior the ventral margin is recurving and slightly convex. In males the anterior end is noticeably narrower than the posterior one. Along the posterior-and anterior margin several randomly distributed cone-shaped pores are present. The ones in the posterior part tend to be higher pronounced. The marginal zone is wide and several simple marginal pore canals are present. The hinge is amphidont and represented by a crenulated bar with one tooth being present at the anterior end and two divided teeth at the posterior end of the LV. Dimension: $\mathrm{L}=0,67$ $-0,70 \mathrm{~mm}, \mathrm{H}=0,30-0,39 \mathrm{~mm}$, the minimum sizes include juveniles too.

Chronostratigraphical and geographical distribution. Within the Paratethys domain L. petasa is known from the Pontian deposits of the Pannonian Basin of Yugoslavia (Sokač, 1972), the upper Pontian (Bosphorian) of the Rîmnicu Sărat Valley in the Dacian Basin (Stoica et al., 2013) and the Pontian from the Bădislava - Topolog area in the South Carpathian foredeep region in Romania (Floroiu et al., 2011). Further it has been described from the Pliocene (Akchagylian and Apsheronian) of the Caspian Basin in Azerbaijan, Turkmenistan (the postPliocene western part of Turkmenistan), the northern Caucasus, the lower Volga Plain and in recent assemblages of the Caspian Sea (Agalarova et al., 1961; Yassini, 44
1986; Sokač, 1990; Van Baak et al., 2013; Lazarev et al., 2019). This species is also known from the Eastern Black Sea region of Turkey (Tunoğlu, 2001).

Ecology. According to the environmental preference of the genus Loxoconcha, L. petasa can be considered a shallow marine indicator (Tunoğlu, 2001). Recent living Loxoconcha species are globally occurring in mesohaline to euryhaline and have been reported from salinities ranging from 4,5 - 13,5 \%o in the Caspian Sea (Yassini, 1986; Gliozzi, 1999).

\section{Loxoconcha ex. gr. petasa (Livental, 1929)}

Fig. 29a-j

Description. These specimens have the same outline as $L$. petasa but display a different kind of ornamentation. The valves surface is covered by a similar but smaller sized and much more irregular pronounced polygonal pattern. Some specimens, in particular juveniles, show a secondary reticulation inside the primary one. The crests that separate the polygons appear thinner and sharper than in L. petasa. Conules pores are pronounced, stronger than in L. petasa and distributed randomly but mainly in the posterior half of the valve. Dimension: $\mathrm{L}=0,65-0,71 \mathrm{~mm}$, $\mathrm{H}=0,36-0,39 \mathrm{~mm}$, the minimum sizes include juveniles too.

\section{Loxoconcha ex. gr. petasa ssp. 1} Fig. 30a-d

Description. The shape of this subspecies resembles the outline of L. petasa. The ornamentation consists of polygonal meshes that vary in size but generally become finer towards the anterior-and posterior margins. In the postero-ventral area of the valve one more or less pronounced tubercle is present and covered in polygonal meshes. From the internal view it can be seen that the tubercle is hollow. The hinge and muscle scar are genus typical. Dimension: $\mathrm{L}=0,58-0,66 \mathrm{~mm}, \mathrm{H}=0,33-0,41$ $\mathrm{mm}$, the minimum sizes include juveniles too.

\section{Loxoconcha ex. gr. petasa ssp. 2} Fig. 30e-k

Description. The outline of the carapace is slightly more compresed than L. petasa. The distinct irregular reticulation that is composed of meshes of different sizes is also present in this species, however in some cases, it is lacking in the posterior area of the valve. Instead, some high pronounced cone-shaped pores are randomly distributed along the posterior margin. Close to the posterodorsaland posteroventral area two tubercles are displayed. They are covered by the primary broad-sized meshes and in some cases with another, finer appearing secondary ornamentation, especially visible in juvenile stages. Dimension: $\mathrm{L}=0,45-0,69 \mathrm{~mm}, \mathrm{H}=0,27-0,40 \mathrm{~mm}$, the minimum sizes include juveniles too.

Remarks. This subspecies shows strong similarties to Loxoconha monticola (Olteanu, 1989) that was described from the Dacian Basin. The presence of hollow tubercles that can be environmentally induced by salinity variations let us assume that this subspecies may very well be a morphotype of L. petasa. 
Genus Loxoconchissa Triebel and Malz, 1969

Subgenus Loxocaspia Schornikov, 1973

\section{Loxoconchissa (Loxocaspia) aff. reticulata Faranda, Gliozzi and Ligios, 2007}

Fig. 31a-j

2007 Loxoconchissa (Loxocaspia) reticulata nov. sp.Faranda, Gliozzi and Ligios, p. 317, fig. 8 (1-10).

2019 Loxoconchissa (Loxocaspia) aff. reticulataRausch and Stoica, p. 60, fig. 16a-p

Description. The carapace has an oval rhomboidal to elliptical shape in the lateral view. The ventral-and dorsal margin run almost parallel with the ventral margin being arched. The straight running dorsal margin passes smoothly onto the broadly rounded anterior end as well as onto the narrower converging posterior end. The maximum width of the carapace is slightly behind mid-length close to where the eye-spot can be observed in the anterodorsal corner. The anterior area is flattened and in the posterior part a well pronounced tubercle is present that in some cases is covered by ornamentation. The tubercle is occurring in both male and female specimens. Within the posterior area the ornamentation in general becomes less pronounced or in some cases is missing entirely. The rest of the valves surface reticulation follows the margins and forms irregular meshes, longitudinal running rows that are separated by more or less thick prounounced ridges. The inner lamella is well developed and extends along the ventral margin. The hinge is amphidont and consists of a crenulated bar. The posterior tooth is bridgeshaped whereas in the anterior a single tooth is present. Dimension: $\mathrm{L}=0,46-0,64 \mathrm{~mm}, \mathrm{H}=0,24-0,39 \mathrm{~mm}$, the minimum sizes include juveniles too.

Geographical and chronostratigraphical distribution. Loxoconchissa (Loxocaspia) aff. reticulata was first described from upper Miocene sediments from northern Italy (Faranda et al., 2007) and from the Pleistocene of the Denizli Basin (Rausch and Stoica, 2019).

Ecology. The family Loxoconchidae is well known from both brackish fossil taxa as well as living genera (Faranda et al., 2007).

\section{Loxoconchissa (Loxocaspia) aff. reticulata Faranda, Gliozzi and Ligios, 2007 var. rugosa n. ssp} Fig. $31 \mathrm{k}$

2019 Loxoconchissa (Loxocaspia) aff. reticulata var. rugosa n. subsp.- Rausch and Stoica, p. 60, fig. $17 \mathrm{a}-0$

Description. The carapace has a rhomboidal shape in lateral view and is covered with a coarse reticulation pattern that consists of polygonal meshes. Randomly distributed large and high pore-conuli are present as well as the distinguishable eye-spot in the anterodorsal corner. The dorsal margin is straight and is smoothly and broadly rounding onto the anterior and posterior ends. The ventral margin is arcuate and the posterior end is noticeable narrower than the anterior end. The preservation of this species in most cases is poor and has only been rarely observed. Dimension: $\mathrm{L}=0,46-0,64 \mathrm{~mm}, \mathrm{H}=0,24-0,39$ $\mathrm{mm}$, the minimum sizes include juveniles too.
Remarks. The species has only been rarely observed in the succession and poorly preserved.

\section{DISCUSSION}

Based on the taxonomic outcome we correlated species to specific environmental conditions with the goal of reconstructing the evolution inside the long-lived lake environment of the Denilzi Basin. The ecological preference of individual species was obtained by comparing fossil ostracod communities with environmental requirements of living species. When no living analogues are present, preference of the species was inferred by using the traditional concept of "taxonomic uniformitarianism", assuming that a fossil has had a similar ecological strategy to its close living relatives (Birks, 2008). The identified ostracod assemblages consist of a mixture of oligohaline to mesohaline tolerant taxa and exposes fundamental differences in their composition in between the two sections.

The assemblage from Section A resembles taxa known from Pannonian to Pontian sequences widespread during the late Miocene in the Pannon Basin (Jiříček, 1985), the Dacian Basin (Olteanu, 1989; Stoica et al., 2013; Van Baak et al., 2015; Lazarev et al., 2020 (submitted)) and the Euxinian Basin (Matzke-Karasz and Witt, 2005; Tunoğlu and Ünal, 2001). The trapezoidal candonids represented by Typhlocypris fossulata fossulata n. ssp., Typhlocypris fossulata reticulata n. ssp and Typhlocyprella sp. display a valve contour similar to those of trapezoidal forms linked to brackish water environments of the Paratethys (Namiotko et al., 2012). Jiříček (1985) for instance described the very similar Typhlocypris fossulata from the upper Pannonian of the Vienna Basin in Austria, Czech Republic and Serbia and Krstić (1972) the uniquely shaped subgenus of Candona (Typhlocyprella). Tunoğlu (2003) mentioned the genus Typhlocypris from the Pontian of Turkey in oligohaline environments and a number of other authors further recognized the genus from different localities inside the Paratethys domain as well (e.g., Carbonnel, 1969; Vekua, 1975; Freels, 1980; Pipik and Bodergat, 2007).

The genus Amnicythere originated in the middle Miocene (Sarmatian) from restricted marine environments inside the Paratethys. It diversified progressively in Lake Pannon and colonized the Eastern Paratethys during the Maeotian and Pontian (Gliozzi et al. 2005; Namiotko et al., 2012). A handful of species of this genus that inhabited low saline to non marine habitats in the past are nowadays found in the Aral Sea and Black and Caspian seas (Gofman, 1966; Stancheva, 1968; Yassini, 1986; Olteanu, 1995; Boomer et al., 2005; Opreanu, 2008; Briceag et al., 2012; Briceag and Ion, 2013). The morphological similarities between the observed species from the Denizli Basin (e.g., Amnicythere multituberculata, A. striatocostata) and species originally existing in Lake Pannon allows us to consider a steeping-stone migration via temporary connection between the Paratethys and the SW Anatolian basins. The same hypothesis was assumed by Albrecht and Wilke (2008) and later supported by results from Namiotko et al. (2012) to be responsible for the occurrence of leptocytherids in Lake Ohrid. We conclude on a similar dispersal scenario and in order to explain the presence of this Paratethyan affine fauna formulate the 


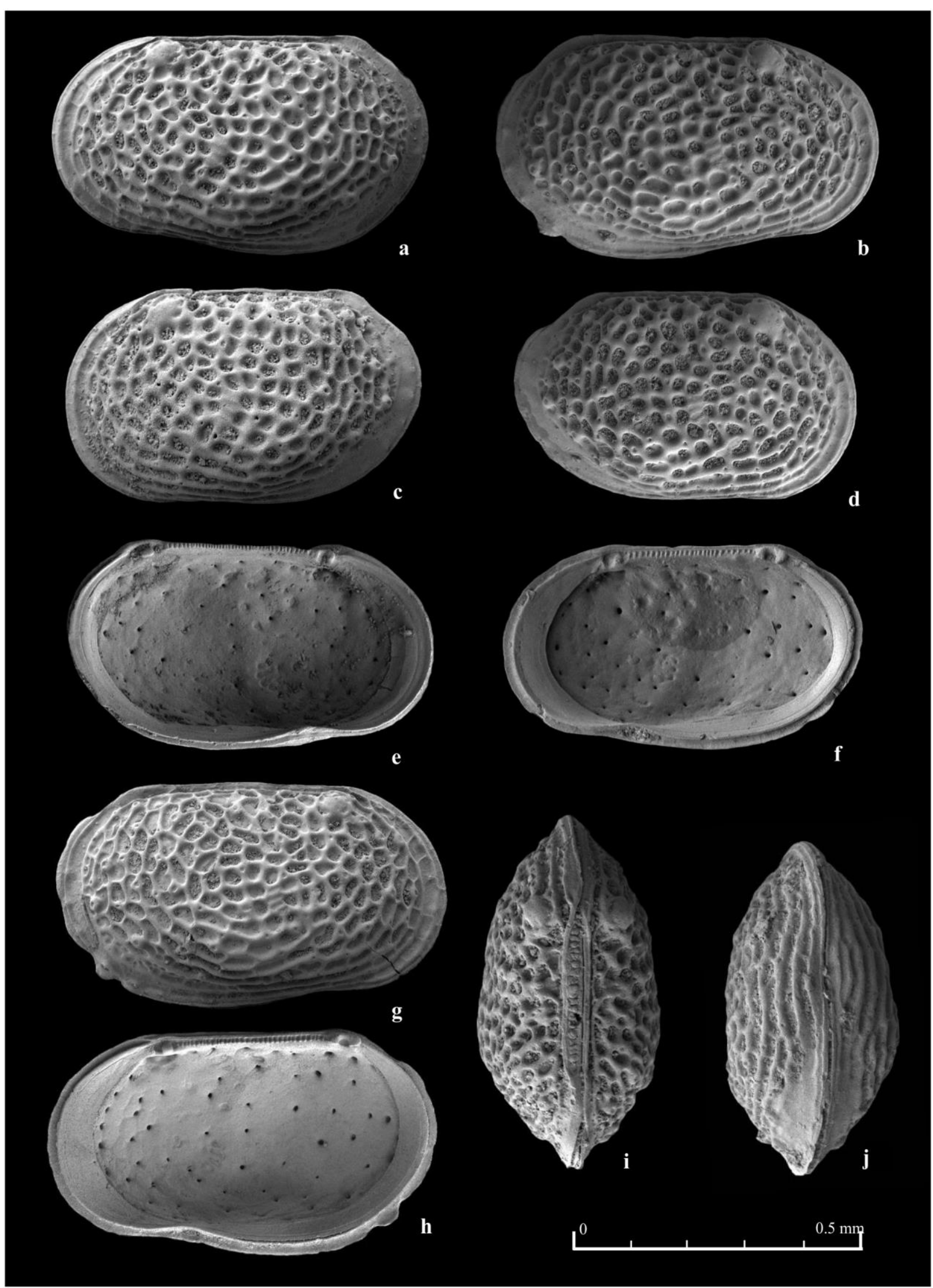

Fig. 28a-j Loxoconcha petasa; a LV, external view, ô; b, g RV, external view, đ̊; c LV, external view, o+; d RV, external view,

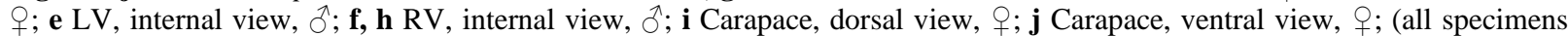
from section B, samples $100 \mathrm{~m}-184,5 \mathrm{~m}$ ). 


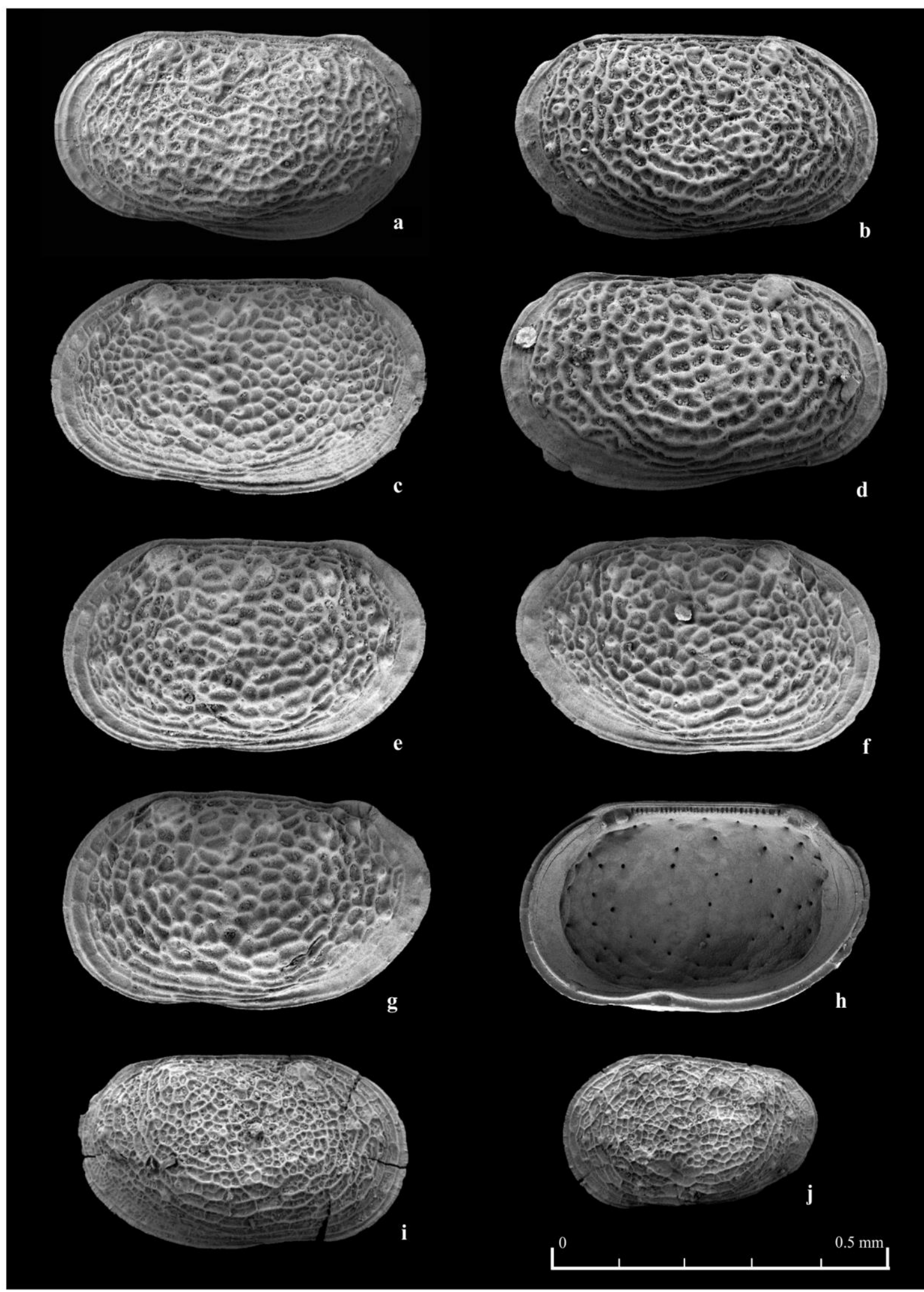

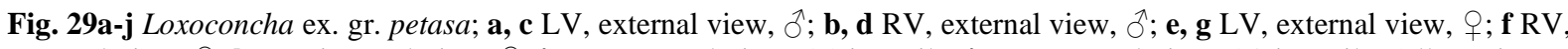
external view, ; $\mathbf{h} \mathrm{RV}$, internal view, + ; i RV, external view, A1 juvenile; j LV, external view, A2 juvenile; (all specimens from section B, sample $84 \mathrm{~m}$ ). 


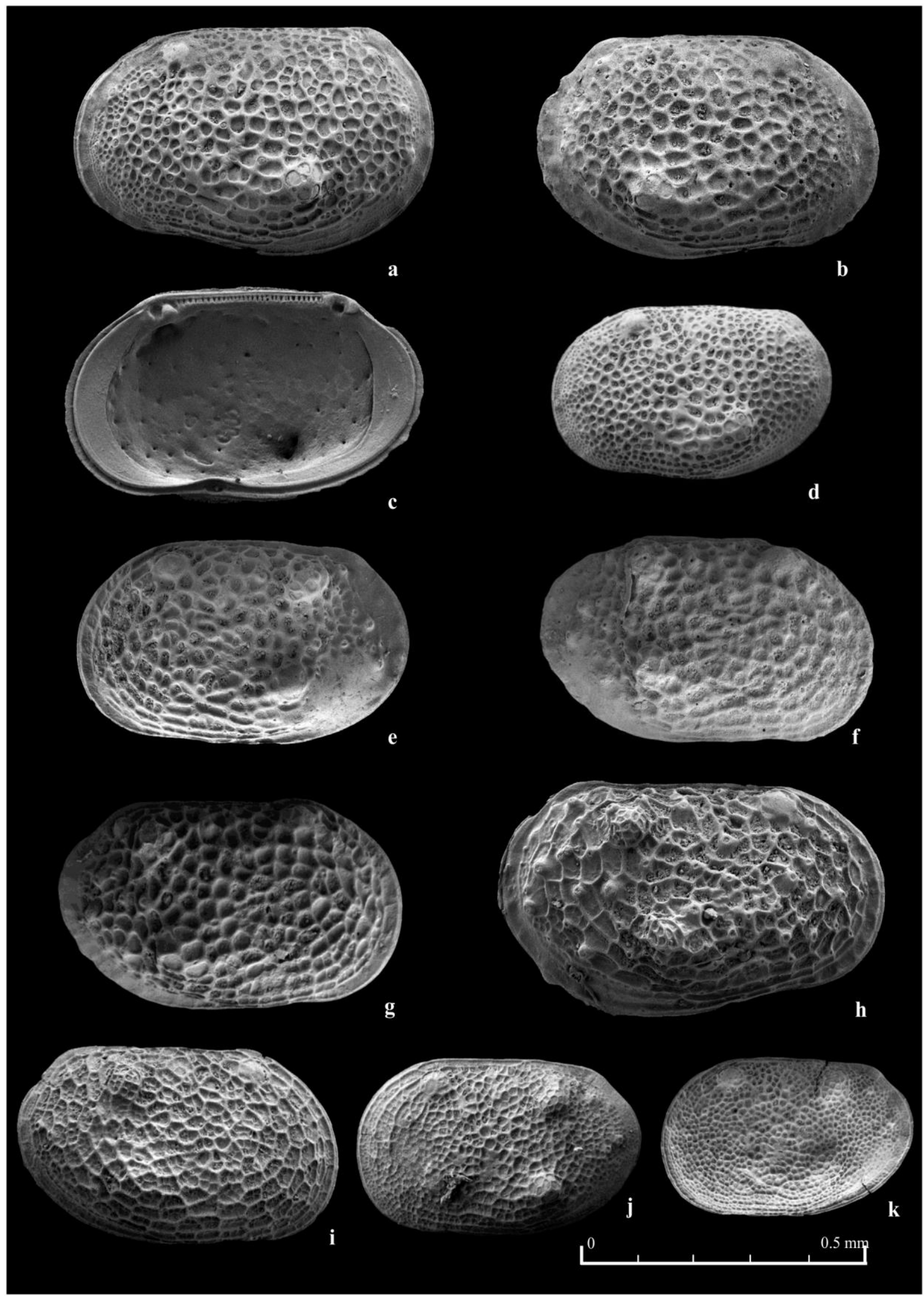

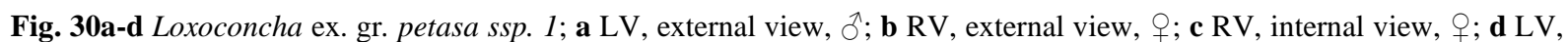
external view, A1 juvenile; e-k Loxoconcha ex. gr .petasa ssp. 2; e LV, external view, $\circ$; f, g RV, extermal view, ; $\mathbf{h}$ RV, external view, of; i RV, external view, A1 juvenile; j LV, external view, A2 juvenile; k LV, external view, A3 juvenile; (all specimens from section $\mathrm{B}$, sample $84 \mathrm{~m}$ ). 


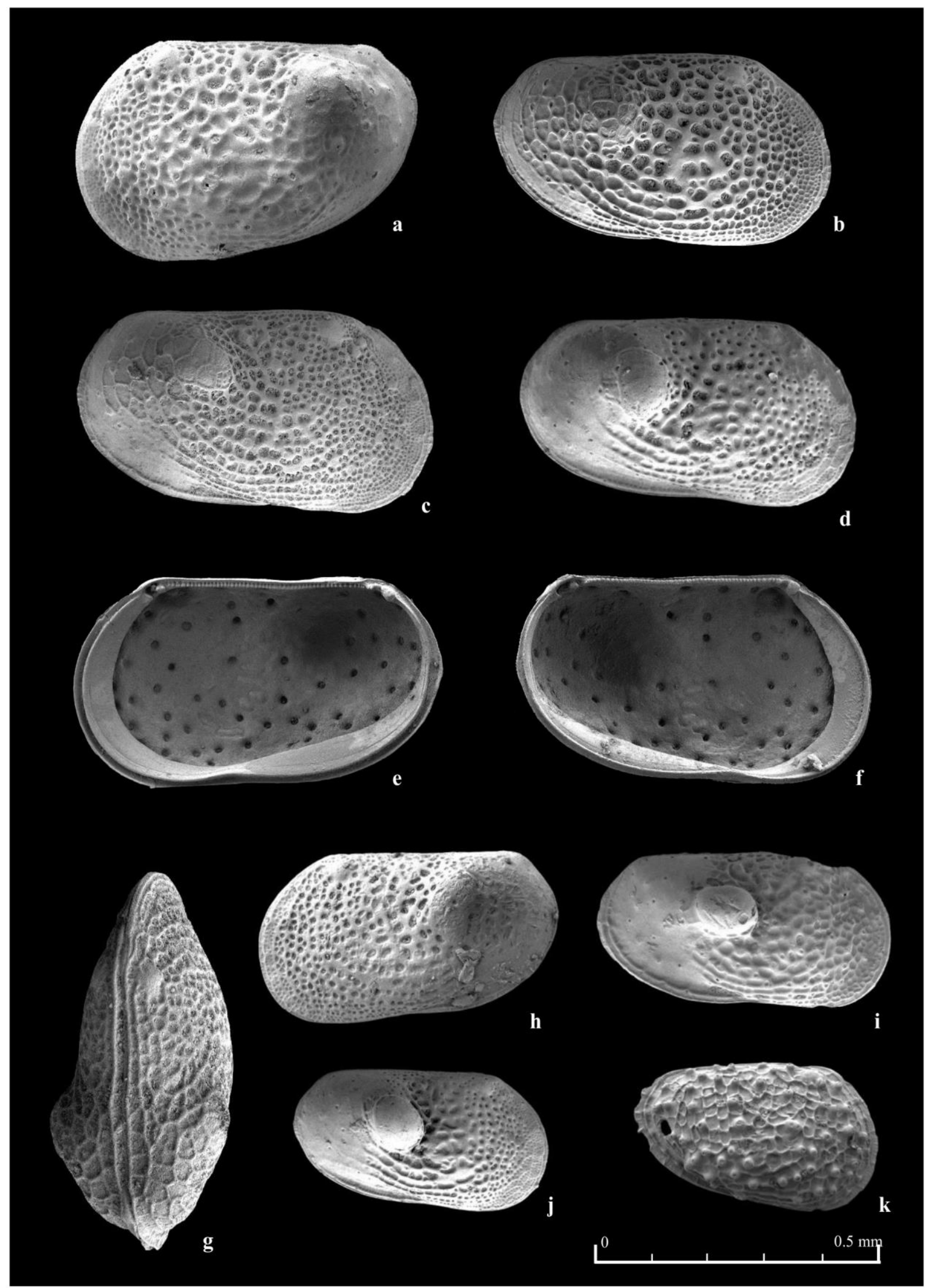

Fig. 31a-j Loxoconchissa (Loxocaspia) aff. reticulata; a LV, external view, $\odot$; b RV, external view, $\odot ;$ c, d RV, external

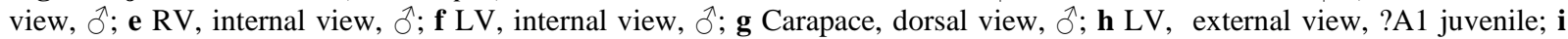
RV, external view, ?A1 juvenile; j RV, external view, A2 juvenile; $\mathbf{k}$ Loxoconchissa (Loxocaspia) aff. reticulata var. rugosa; $\mathrm{RV}$, external view, ; ; (all specimens from section A; a-j samples $0 \mathrm{~m}-35,5 \mathrm{~m}$; $\mathrm{k}$ samples $18 \mathrm{~m}$ ) 
following hypothesis: 1) Re-establishment of interbasinal connectivity between the Paratethys via the Aegean region to the Denzili Basin during highstands, allowed faunal migration via a yet unknown intra-west Anatolian gateway. Late Miocene Paratethyan mollusc and ostracod assemblages are widespread in the Aegean basin, evidenced by their presence in many sections in northern Greece and western Turkey (e.g., Popov and Nevesskaya, 2000; Popov et al., 2006; Sakınç and Yaltırak, 2005; Karakitsios et al., 2017). This suggests that the Aegean region was connected to the former Black Sea domain and probably formed (at least) a southern embayment of the Paratethys. When this shallow marine gateway specifically came into existence and the exact position are still uncertain. However, the gateway played a significant role during the Messinian Salinity Crisis (MSC), when the Mediterranean was disconnected from the Atlantic Ocean (e.g., Krijgsman et al., 2010; Stoica et al., 2016). The transition from hypersaline evaporitic facies to a freshbrackish Lago-Mare setting, favored the migration of Paratethyan faunas into the Mediterranean basin (Cita et al., 1978; Gliozzi, 1999; Gliozzi et al., 2007; Stoica et al., 2016). The Aegean migration corridor enabled other Paratethyan invertebrates such as molluscs (Didacna spp.; Wesselingh et al., 2008) to colonize the Denzili Basin as well, suggesting that the region was once a connected paleo-bay of the Paratethys (Freels, 1980; Wesselingh et al., 2008; Van Baak et al., 2016). It further proves that the influence of the Paratethys reached further south than previously thought. Further investigations in SW Anatolia would contribute towards a better understanding of the southern border of the Paratethys, the location of the gateways, whenever the region functioned as a refugium for Paratethyan taxa and contribute towards a better age determination. The fauna most likely is of late Miocene age, but lacks the presence of clear stratigraphic marker species and a precise palaeomagnetic pattern; 2) long distance dispersal (LDD) via migratory water birds. Brochet et al. (2009) report on the transport of ostracods and other aquatic invertebrates as a widespread phenomenon over distances up to $700 \mathrm{~km}$. Creating a fauna this similar would however require the presence of the same palaeoecological conditions like inside the Paratethys. Without there being a connection, this scenario is highly unlikely.

A strong change in the faunal composition takes place at the base of the Section B. The poorly diverse ostracod assemblage indicates an oligohaline-mesohaline water environment that can reach up to $200 \mathrm{~m}$ in depth with a fine substrate at the bottom that favoured the development of an ostracod community that is dominated by candonids (Candona angulata, $C$. ex. gr. angulata) and loxoconchids (Loxoconcha muelleri, L. eichwaldi). The assemblage slightly diversifies at $23 \mathrm{~m}$ and the valves appear more calcified, suggesting a minor increase in alkalinity. Besides the dominance of $C$. angulata and $L$. eichwaldi few levels along the succession with an increasing presence of nodded Cyprideis torosa as well as L. petasa and L. mulleri can be found. From 61,5 m onwards additional species occur, including L. petasa ssp. 1, L. petasa ssp. 2, Euxinocythere (Maeotocythere) bosqueti, A. sp. 1 and A. sp.2. Thicker and more ornate valves are observed, that can be interpreted as the organ50 ism's response to changing hydrodynamic conditions related to episodes of shoreline progradation described in the upper part of the Kolankaya formation (Alçiçek et al., 2007). Since most of the samples were however taken from fine-grained intervals, mainly associated to lacustrine and distal fan environments, we conclude that the main driver behind minor shifts in the faunal composition are the results of minor changes in salinity rather than the response of the ostracods to the sedimentary environment.

\section{CONCLUSION}

The investigated late Miocene - early Pliocene deposits from the Denizli Basin (SW Anatolia, Turkey) document a faunal turnover inside a transitioning long-lived lake environment. The ostracod assemblage reflects two distinct patterns related to the evolution of the basin: faunal migration of a Paratethys influenced fauna and the diversification of an endemic community. The encountered assemblages are suggesting a late Miocene - early Pliocene age. Improvements in dating and correlation with the mammal bearing horizons from the Kolankaya Formation are required. We suggest that the ostracod fauna reached the Denizli Basin from the Paratethys via the Aegean Sea along a temporary connection, which was presumably made during periods of high-water level stands. The exact migration time and path however remain to be established still. The occurring faunal turnover towards a low brackish dominated assemblage, occurring presumably at the beginning of the early Pliocene, can be traced back to the progressive instability and increasing isolation of the basin. The extensional character of the basin and regional climate changes are concluded to be the main drivers for the observed faunal turnovers.

\section{ACKNOWLEDGEMENTS}

We thank Hülya and Cihat Alçiçek for their valuable contribution on the geology of the Denizli Basin and their support during fieldwork. We thank Chris Van Baak, Sabrina van de Velde, Gülcin Aygun, Wout Krijgsman, Hemmo Abels and Frank Wesseling for their help in the field. We further thank the Microcosmos Laboratory from the Geological Institute of Romania for providing access to the scanning electron microscope (SEM) necessary for taking the high-resolution images. We are grateful to Andrei Briceag (GeoEcoMar Bucharest) and Viorel Ionesi (University of Iaşi) for improving the manuscript. This research was funded by the PRIDE project, which received funding from the European Union's Horizon 2020 research and innovation programme under the Marie Sklodowska-Curie grant agreement No. 642973.

\section{REFERENCES}

Agalarova, D. A., 1967. Microfauna der Ponthischen Ablagerungen Aserbeidschans und der angrenzenden Gebiete. Az Nil po Dobyce Nefti A, 204, 123.

Agalarova, D.A., Kadyrova, Z.K. and Kulieva, S.A., 1961. Ostracoda from Pliocene and Post-pliocene deposits of Azerbaijan. Baku, 1-420. 
Albrecht, C. and Wilke, T., 2008. Ancient Lake Ohrid: biodiversity and evolution. Hydrobiologia, 615(1), 103-140.

Alçiçek, H., 2010. Stratigraphic correlation of the Neogene basins in southwestern Anatolia: regional palaeogeographical, palaeoclimatic and tectonic implications. Palaeogeography, Palaeoclimatology, Palaeoecology, 291(3-4): 297-318.

Alçiçek, H., Varol, B. and Özkul, M., 2007. Sedimentary facies, depositional environments and palaeogeographic evolution of the Neogene Denizli Basin of SW Anatolia, Turkey. Sedimentary Geology 202: 596-637.

Alçiçek, H., Wesselingh, F.P. and Alçiçek M.C., 2015. Paleoenvironmental evolution of the late Plioceneearly Pleistocene fluvio-deltaic sequence of the Denizli Basin (SW Turkey). Palaeogeography, Palaeoclimatology, Palaeoecology 437, 98-116.

Alivernini, M., Akita, L. G., Ahlborn, M., Börner, N., Haberzettl, T., Kasper, T., Plessen, B., Peng, P., Schwalb, A., Wang, J and Frenzel, P., 2018. Ostracod-based reconstruction of Late Quaternary lake level changes within the Tangra Yumco lake system (southern Tibetan Plateau). Journal of Quaternary Science, 33(6), 713-720.

Belis, C. A., Lami, A., Guilizzoni, P., Ariztegui, D. and Geiger, W., 1999. The late Pleistocene ostracod record of the crater lake sediments from Lago di Albano (Central Italy): changes in trophic status, water level and climate. Journal of Paleolimnology, 21(2), 151169.

Belmecheri, S., Namiotko, T., Robert, C., von Grafenstein, U. and Danielopol, D. L., 2009. Climate controlled ostracod preservation in Lake Ohrid (Albania, Macedonia). Palaeogeography, Palaeoclimatology, Palaeoecology, 277(3-4), 236-245.

Benson, R. H., 1976. Changes in the ostracodes of the Mediterranean with the Messinian salinity crisis. Palaeogeography, Palaeoclimatology, Palaeoecology, 20(1-2), 147-170.

Birks, H. J. B., 2008. Paleoecology. In: Jørgensen S.E. (Ed.) Encyclopedia of Ecology. Elsevier, Oxford, 2623-2634.

Boomer, I., Whatley, R. and Aladin, N. V., 1996. Aral Sea Ostracoda as environmental indicators. Lethaia, 29(1), 77-85.

Boomer, I., von Grafenstein, U., Guichard, F. and Bieda, S., 2005. Modern and Holocene sublittoral ostracod assemblages (Crustacea) from the Caspian Sea: a unique brackish, deep-water environment. Palaeogeography, Palaeoclimatology, Palaeoecology, 225(1-4), 173-186.

Boomer, I., Guichard, F. and Lericolais, G., 2010. Late Pleistocene to Recent ostracod assemblages from the western Black Sea. Journal of Micropalaeontology, 29(2), 119-133.

Bozkurt, E., 2001. Neotectonic of Turkey-a synthesis. Geodinamica Acta 14, 3-30.

Brady, G. S. and D. Robertson, 1870. The Ostracoda and Foraminifera of tidal rivers. The Annals and Magazine of Natural History 4: 1-33.

Briceag, A., Stoica, M., Oaie, G. and MelinteDobrinescu, M. C., 2012. Late Holocene microfaunal and nannofloral assemblages of the NW Black Sea. GeoEcoMarina, 18, 65-73.

Briceag, A. and Ion, G., 2013. Holocene ostracod and foraminiferal assemblages of the Romanian Black Sea shelf. Quaternary International, 30(1), e11.

Brochet, A. L., Guillemain, M., Fritz, H., Gauthier-Clerc, M. and Green, A. J., 2009. The role of migratory ducks in the long-distance dispersal of native plants and the spread of exotic plants in Europe. Ecography, 32(6), 919-928.

Carbonnel, G., 1969. Les ostracodes du Miocène Rhodanien: Systématique, biostratigraphie écologique, paléobiologie (No. 32). Laboratoires de géologie de la Faculté des sciences de Lyon, 469 p.

Carbonnel, G., 1978. La zone a Loxoconcha djaffarovi Schneider (Ostracoda, Miocène supérieur) ou le Messinien de la Vallée du Rhône. Revue de Micropaléontologie, 21(3), 106-118.

Carbonnel, G. and Jiříček, C. C., 1977. Super-zones et datums à Ostracodes dans le Néogène de la Téthys (bassin du Rhône) et de la Paratéthys. Newsletters on Stratigraphy, 23-29.

Cita, M.B., Wright, R.C., Ryan, W.B.F. and Longinelli, A., 1978. Messinian paleoenvironments. Initial Report Deep Sea Drilling Project 42, 1003-1035.

Cziczer, I., Magyar, I., Pipík, R., Böhme, M., Ćorić, S., Bakrač, K., Szentai, M.S., Lantos, M., Babinszki, E. and Müller, P., 2009. Life in the sublittoral zone of long-lived Lake Pannon: paleontological analysis of the Upper Miocene Szák Formation, Hungary. International Journal of Earth Sciences, 98(7), 1741.

Danielopol, D. L., Geiger, W., Tölderer-Farmer, M., Orellana, C. P. and Terrat, M. N., 1985. The Ostracoda of Mondsee: spatial and temporal changes during the last fifty years. Contributions to the Paleolimnology of the Trumer Lakes (Salzburg) and the Lakes Mondsee, Attersee and Traunsee (Upper Austria); Limnologisches Institut der Österreichischen Akademie der Wissenschaften: Mondsee; 99, 119.

De Deckker, P. and Forester, R. M., 1988. The use of ostracods to reconstruct continental palaeoenvironmental records. Ostracoda in the earth sciences. Elsevier, Amsterdam, 175-199.

De Deckker, P. and Lord, A., 2017. Cyprideis torosa: a model organism for the Ostracoda? Journal of Micropalaeontology, 36(1), 3-6.

Devoto, G., 1967. Studio delle ostracofaune. In: Colacicchi, Devoto, G., Praturlon, A., Depositi messiniani oligoalini al bordo orientale del Fucino e descrizione di Tyrrhenocythere ruggierii Devoto, nuova specie di ostracode. Bollettino della Società geologica italiana. 86, 21-37.

Diebel, K. and Pietrzeniuk, E., 1969. Ostracoden aus dem Mittelpleistozän von Süßenborn bei Weimar. Paläontologische Abhandlungen, 3, 463-488.

Faranda, C., Gliozzi, E. and Ligios, S., 2007. Late Miocene brackish Loxoconchidae (Crustacea, Ostracoda) from Italy. Geobios, 40(3), 303-324.

Floroiu, A., Stoica, M., Vasiliev, I. and Krijgsman, W., 2011. Maeotian/Pontian ostracods in the BadislavaTopolog Area (South Carpathian Foredeep Romania). GeoEcoMarina, 17, 237-244. 
Floroiu, A., Stoica, M., Vasiliev, I. and Krijgsman, W., 2016. Late Miocene/Pliocene Ostracod Biostratigraphy from South Carpathian Foredeep, Romania (Badislava-Topolog Area). In EGU General Assembly Conference Abstracts (Vol. 18).

Freels, D., 1980. Limnische Ostrakoden aus Jungtertiar und Quartar der Turkei. Geologisches Jahrbuch, 39, 3-169.

Fuhrmann, R., 2008. Die Ostrakoden-und Molluskenfauna des Auelehmprofils Zeitz (Landkreis Burgenland) und ihre Aussage zum Klima sowie zur Landnutzung im jüngeren Holozän Mitteldeutschlands. Mauritiana, 20(2), 253-281.

Fuhrmann, R., 2012. Atlas quartärer und rezenter Ostrakoden Mitteldeutschlands (pp. 1-320). Altenburg: Naturkundliches Museum Mauritianum.

Fuhrmann, R. and Pietrzeniuk, E., 1990. Die Ostrakodenfauna des Interglazials von Grabschütz (Kreis Delitzsch). Altenbg. nat. wiss. Forsch, 5, 202227.

Gauthier, H., 1928. Recherches sur la faune des eaux continentales de l'Algérie et de la Tunisie. Minerva, 3.

Gliozzi, E., 1999. A late Messinian brackish water ostracod fauna of Paratethyan aspect from Le Vicenne Basin (Abruzzi, central Apennines, Italy). Palaeogeography, Palaeoclimatology, Palaeoecology, 151(1-3), 191-208.

Gliozzi, E., Rodriguez-Lazaro, J., Nachite, D., MartinRubio, M., and Bekkali, R., 2005. An overview of Neogene brackish leptocytherids from Italy and Spain: Biochronological and palaeogeographical implications. Palaeogeography, Palaeoclimatology, Palaeoecology, 225(1-4), 283-301.

Gliozzi, E., Ceci, M. E., Grossi, F. and Ligios, S., 2007. Paratethyan ostracod immigrants in Italy during the Late Miocene. Geobios, 40(3), 325-337.

Gliozzi, E. and Grossi, F., 2008. Late Messinian lagomare ostracod palaeoecology: A correspondence analysis approach. Palaeogeography, Palaeoclimatology, Palaeoecology, 264(3-4), 288-295.

Gofman, E. A. E., 1966. Ekologija sovremennych i novokaspijskich ostrakod Kaspijskogo morja. Izd. Hauka, 1-183.

Grigorovich, I. A., Therriault, T. W. and MacIsaac, H. J., 2003. History of aquatic invertebrate invasions in the Caspian Sea. In Pederson J. (Ed.), Marine bioinvasions: Patterns, processes and perspectives, Biological Invasions 5 (1-2), p. 103-115. Springer, Dordrecht.

Grossi, F., Gliozzi, E., Anadón, P., Castorina, F. and Voltaggio, M., 2015. Is Cyprideis agrigentina Decima a good paleosalinometer for the Messinian Salinity Crisis? Morphometrical and geochemical analyses from the Eraclea Minoa section (Sicily). Palaeogeography, Palaeoclimatology, Palaeoecology, 419, 75-89.

Guernet, C., Keraudren, B. and Sauvage, J., 1976. La série «levantine» du Cap Phocas (Île de Kos, Dodécanèse, Grèce): stratigraphie, palynologie et paléoécologie. Revue de Micropaléontologie, 19(2), 61-76.

Guerra-Merchán, A., Serrano, F., Garcés, M., Gofas, S., Esu, D., Gliozzi, E. and Grossi, F., 2010. Messinian Lago-Mare deposits near the strait of Gibraltar (Mala52 ga Basin, S Spain). Palaeogeography,
Palaeoclimatology, Palaeoecology, 285(3-4), 264276.

Hartmann, G., 1966. Ostracoda, In: Dr. H.G. Bronns Klassen und Ordnungen des Tierreichs, 5. Arthropoda, 1. Crustacea, 2(4/1): 1-216.

Harzhauser, M., Piller, W. E. and Steininger, F. F., 2002. Circum-Mediterranean Oligo-Miocene biogeographic evolution - the gastropods' point of view. Palaeogeography, Palaeoclimatology, Palaeoecology, 183(1-2), 103-133.

Hauffe, T., Albrecht, C. and Wilke, T., 2015. Gastropod diversification and community structuring processes in ancient Lake Ohrid: a metacommunity speciation perspective. Biogeosciences Discussions, 12(18).

Henderson P.A., 1990. Freshwater Ostracods: keys and notes for the identification of the species. In: Kermack DM, Barnes RSK (eds) Synopsis of the British Fauna 42. Universal Book Series and Backhuys Publishers, Oegstgeest, pp 1-228.

Holmes, J. A., 1992. Nonmarine ostracods as Quaternary palaeoenvironmental indicators. Progress in Physical Geography, 16(4), 405-431.

Horne, D. J., Cohen, A. and Martens, K., 2002. Taxonomy, morphology and biology of Quaternary and living Ostracoda. The Ostracoda: Applications in Quaternary Research, Geophysical Monograph, 131, 5-36.

Jiříček, R., 1983. Redefinition of the Oligocene and Neogene ostracod zonation of the Paratethys. Knihovnička Zemního plynu a nafty, 4, 195-236.

Jiř́čck, R., 1985. Die Ostracoden des Pannonien. Chronostratigraphie und Neostratotypen, Miozän der Zentralen Paratethys. Pannonien.-7 M, 6, 378-425.

Jones, T.R., 1850. Description of the Entomostraca of the Pleistocene Beds of Newbury Copford, Clacton and Grays. The Annals and magazine of natural history. 6(2): 25-28.

Jordan, H., Bernstorff, U. and Gründel, J., 1962. Die Ostracoden des Älteren Travertins (Pleistozän) von Mühlhausen (Thür). Freiburger Forschungshefte, $C$, $125,65-126$.

Jorissen, E. L., de Leeuw, A., van Baak, C. G., Mandic, O., Stoica, M., Abels, H. A. and Krijgsman, W., 2018. Sedimentary architecture and depositional controls of a Pliocene river-dominated delta in the semi-isolated Dacian Basin, Black Sea. Sedimentary geology, 368, $1-23$.

Jovanovska, E., Cvetkoska, A., Hauffe, T., Levkov, Z., Wagner, B., Sulpizio, R., Francke, A., Albrecht, C. and Wilke, T., 2016. Differential resilience of ancient sister lakes Ohrid and Prespa to environmental disturbances during the Late Pleistocene. Biogeosciences 13, 1149-1161.

Karakitsios, V., Cornée, J. J., Tsourou, T., Moissette, P., Kontakiotis, G., Agiadi, K., Manoutsoglou, E., Triantaphyllou, M., Koskeridou, E., Drinia, H. and Roussos, D., 2017. Messinian salinity crisis record under strong freshwater input in marginal, intermediate, and deep environments: The case of the North Aegean. Palaeogeography, Palaeoclimatology, Palaeoecology, 485, 316-335.

Karanovic, I., 2005. On the genus Typhlocypris Vejdovský, 1882 (Crustacea: Ostracoda: Can- 
doninae), with description of two new species. Systematics and Biodiversity, 3(4), 375-406.

Kaymakç1, N., 2006. Kinematic development and paleostress analysis of the Denizli Basin (Western Turkish): implications of spatial variation of relative paleostress magnitudes and orientations. Journal of Asian Earth Sciences 27, 207-222.

Kazmina, T. A., 1975. Stratigraphy and ostracodes of Pliocene and early Pleistocene in southern West Siberian Plain (İn Russian): Transactions of the Institute of Geology and Geophysics, 1-108.

Kempf, E. K. and Scharf, B. W., 1980. Lebende und fossile Muschelkrebse (Crustacea: Ostracoda) vom Laacher See. Mitteilungen der Pollichia, 68, 205-236.

Konak, N. and Şenel, M., 2002. Geological map of Turkey in 1/500.000 scale: Denizli sheet. Publication of Mineral Research and Exploration Directorate of Turkey (MTA), Ankara.

Krijgsman, W., Stoica, M., Vasiliev, I. and Popov, V. V., 2010. Rise and fall of the Paratethys Sea during the Messinian Salinity Crisis. Earth and Planetary Science Letters, 290(1-2), 183-191.

Krijgsman, W., Tesakov, A., Yanina, T., Lazarev, S., Danukalova, G., Van Baak, G.C.G., Agustí, J., Alçiçek, M.C., Aliyeva, E., Bista, D., Bruch, A., Büyükmeriç, Y., Bukhsianidze, M., Flecker, R., Frolov, P., Hoyle, T.M., Jorissen, E.L., Kirscher, U., Koriche, S.A., Oms, O., Rausch, L., Singarayer, J., Stoica, M., Van de Velde, S.V., Titov, V.V., Wesselingh, F.P., 2019. Quaternary time scales for the Pontocaspian domain: interbasinal connectivity and faunal evolution. Earth Science Reviews 188, 1-40.

Krstić, N., 1972. Roda Candona (Ostracoda) iz kongerijskich slojeva južnog dela Panonskog basena. Srpska akademija nauka i umetnosti, 39, 1-145.

Krstić, N., 1973. Biostratigrafija kongerijskih slojeva okoline Beograda na osnovu ostrakoda sa opisom vrsta roda Amplocypris [Biostratigraphy of the Congerian beds in the Belgrade region on the basis of ostracoda - in Serbian with English summary].- Institute for Geological and Mining Exploration and Investigation of Nuclear and Other Mineral Raw Materials, Monographs, 4, $158 \mathrm{p}$.

Krstić, N., 1977. The ostracod genus Tyrrhenocythere. In Aspects of ecology and zoogeography of Recent and fossil Ostracoda (pp. 395-405). Dr. W. Junk bv Publishers The Hague.

Krstić, N., 1985. Ostracoden im Pannonien der Umgebung von Belgrad. In: Papp, A., Jambor, A., Steininger, F. (Eds.), Chronostratigraphie und Neostratotypen, Miozän M 6, 103-143.

Krstić, N., 1989. Contribution by Ostracods to the definition of the boundaries of the Pontian in the Pannonian Basin. - In: Malez, M. and Stevanović, P. (Eds.): Chronostratigraphie und Neostratotypen, Neogen der Westlichen (,Zentralen”) Paratethys. Pontien. 8(P11): Verlag der Jugoslawischen Akademie der Wissenschaften und Künste und der Serbischen Akademie der Wissenschaften und Künste, Zagreb/Belgrad, pp. 45-75.

Krstić, N. and Stancheva, M., 1989. Ostracod of Eastern Serbia and Northern Bulgaria with notices on a Northern Turkey assemblage and some Mediterranean assemblages. In: Malez, M. and Stevanović, P. (Eds.), Chronostratigraphie und Neostratotypen: Neogen der Westlichen ('Zentrale") Paratethys 8. Pontien (1989)., Verlag der Jugoslawischen Akademie der Wissenschaften und Künste und der Serbischen Akademie der Wissenschaften und Künste, Zagreb/Belgrad), pp. 753-819.

Lazarev, S., Jorissen, E.L., van de, Velde, S., Rausch, L., Stoica, M., Wesselingh, F.P., van, Baak, C.G.C., Yanina, T.A., Aliyeva, E. and Krijgsman, W., 2019. Magnetobiostratigraphic age constraints on the palaeoenvironmental evolution of the South Caspian Basin during the Early- Middle Pleistocene (Kura Basin, Azerbaijan). Quaternary Science Reviews, 222, 1-26.

Lazarev, S., Leeuw, A. de, Stoica, M., Mandic, O., van Baak, C.G.C., Vasiliev, I., Krijgsman, W., 2020 (submitted). From Khersonian drying to Pontian flooding: late Miocene stratigraphy and palaeoenvironmental evolution of the Dacian Basin (Eastern Paratethys). Global and Planetary Change.

Lister, G. S., 1988. Stable isotopes from lacustrine Ostracoda as tracers for continental palaeoenvironments. In: De Deckker, P., Colin, J.-P. and Peypouquet J.-P. (Eds) Ostracoda in the Earth Science. Elsevier, Amsterdam, pp. 201-208.

Livental, V. E., 1929. Ostracoda of Akchagilian and Apsheronian beds of the Babazan Section. Izvestiya Azerbajdzahnskogo Politekhnischeskogo Instituta, 1, 1-58 (in Russian).

Lorenschat, J., Pérez, L., Correa-Metrio, A., Brenner, M., von Bramann, U. and Schwalb, A. , 2014. Diversity and spatial distribution of extant freshwater ostracodes (Crustacea) in ancient Lake Ohrid (Macedonia/Albania). Diversity, 6(3), 524-550.

Mandelstam, M. I., Markova, L. P., Rozieva, T. R., \& Stepanajtys, N. E., 1962. Ostrakody pliotzenovyh i postpliotzenovyh olotzenii Turkmenistana. Izvestija Akademii Nauk Turkmenskoj SSR, 1-287.

Mandelstam, M. I. and Schneider, G. F., 1963. Les ostracodes fossiles de l'USSR, famille Cyprididae. Trudy VNIGRI, 203, 1-242.

Martens, K., 1994. Ostracod speciation in ancient lakes: a review. Ergebnisse der Limnologie, 44, 203-203.

Martens, K. and Schön, I., 1999. Crustacean biodiversity in ancient lakes: a review. Crustaceana, 72(8), 899910.

Matzke-Karasz, R. and Witt, W., 2005. Ostracods of the Paratethyan Neogene Kılıç and Yalakdere Formations near Yalova (İzmit Province, Turkey). Zitteliana, A45, 115-133.

Medici, M. C., Ceci, M. E. and Gliozzi, E., 2011. Early Pliocene brackish and freshwater ostracoda from the Valdelsa basin (Tuscany, Central Italy). Rivista Italiana di Paleontologia e Stratigrafia (Research In Paleontology and Stratigraphy), 117(3), 473-500.

Méhes, G., 1908. Beiträge zur Kenntnis der Pliozänen ostrakoden Ungarns. II Die Darwinulidaeen und Cytherideaidaeen der unterpannonischen Stufe. Supplement Földtani Közlöny, 38, 601-635.

Meisch, C., 2000. Crustacea: Ostracoda. Süßwasserfauna von Mitteleuropa. In: Schwoerbel J. \& Zwick P. (Eds.): Süßwasserfauna von Mitteleuropa. - 8(3): 1- 
522, Spektrum Akademischer Verlag, Heidelberg/Berlin.

Moore, R. C., 1961. Glossary of morphological terms applied to Ostracoda. In: Moore, R.C., (Ed.) Treatise on Invertebrate Paleontology, Part Q, Arthropoda, 3, 47-56, Geological Society of America and University of Kansas Press, Kansas.

Müller, G. W., 1900. Deutschlands SüßwasserOstracoden. Zoologica, Orginalabhandlungen aus dem Gesamtgebiet der Zoologie, Stuttgart 12 (30): 1112.

Namiotko, T., Danielopol, D. L., Belmecheri, S., Gross, M. and Von Grafenstein, U., 2012. On the Leptocytheridae Ostracods of the Long-Lived Lake Ohrid: A Reappraisal of their Taxonomic Assignment and Biogeographic Origin. International review of hydrobiology, 97(4), 356-374.

Neale, J. W., 1988. Ostracods and paleosalinity reconstruction: In: DeDeckker, O., Colin, J.P. and Peypouquet J.-P. (Eds.). Ostracoda in the Earth Sciences, Elsevier Publications 125-155.

Nebert, K., 1958. Die pliozänen Ablagerungen von Denizli und ihre Bedeutung für die Stratigraphie des westanatolischen Süßwasserneogens. Bulletin of Mineral Research and Exploration, Turkey, 51: 7-18.

Olteanu, R., 1978. Ostracoda from DSDP Leg 42B. Initial Reports of the Deep-Sea Drilling Project, 42(2), 1017-1038.

Olteanu, R., 1982. Genus Tyrrhenocythere Ruggieri, in the Dacic Basin. Dări de Seamă ale Ședințelor Institutul de Geologie și Geofizică, 3. Paleontologie, 69, 47-58.

Olteanu, R.., 1989. La faune d'ostracodes pontiens du Bassin Dacique. In: Malez, M. and Stevanović, P. (Eds.), Chronostratigraphie und Neostratotypen Pliozän Neogen der Zentrale Paratethys, Bd.VIII Pontien, Jugosl. Akad.Wissenund Künste, pp.722726.

Olteanu, R., 1995. Dacian ostracodes. In: Marinescu Fl., Papainopol, I. (Eds.), Chronostratigraphie und Neostratotypen, Neogene der Zentrale Paratethys, PL 1 Dacien IX, 268-386.

Olteanu, R., 1998. Orthogenesis and orthoselection. Leptocythere lineages in brackish-water Neogene (Ostracoda). Revue roumaine de géologie géophysique et géographie, 42, 141-153.

Olteanu, R., 2001. Hemicytherinae Subfamily (Ostracoda, Crustacea) and its Species in Paratethys BrackishWater Facieses (Neogene, Carpathian Areas). Their Morphology and Taxonomy. Studii si cercetari de Geologie, 46, 71-110.

Olteanu, R., 2011. Atlas of the Pannonian and Pontian Ostracods from the Eastern area of the Pannonian Basin. GeoEcoMarina, 17, 135-177.

Opreanu, P. A., 2008. Ostracode relicte Ponto-Caspice în sectorul Românesc al Mării Negre. GeoEcoMarina, 14(Suppl. 1), 57-62.

Palcu, D. V., Vasiliev, I., Stoica, M., Krijgsman, W., 2019. The end of the Great Khersonian Drying of Eurasia: Magnetostratigraphic dating of the Maeotian transgression in the Eastern Paratethys. Basin Research, 31,33-58.
Petkovski, T., 1958. Zwei neue Ostracoden aus dem Dorjansee. Bioloski glasnik, 11, 27-34.

Pipík, R. and Bodergat, A. M., 2007. Upper Miocene trapezoidal candoninae (Crustacea, ostracoda) of the turiec basin (Slovakia): Systematics, ecology and evolution. Geobios, 40(5), 645-676.

Pokorný, V., 1952. The ostracods of the so-called basal horizon of the subglobosa beds at Hodonin (Pliocene, Inner Alpine Basin, Czechoslovakia). Sborník Ústřdního Ústavu Geologického, 19, 229-396.

Popov, S. V. and Nevesskaya, L. A., 2000. Late Miocene brackish-water mollusks and the history of the Aegean Basin. Stratigraphy and Geological Correlation, 8(2), 195-205.

Popov, S. V., Shcherba, I. G., Ilyina, L. B., Nevesskaya, L. A., Paramonova, N. P., Khondkarian, S. O. and Magyar, I., 2006. Late Miocene to Pliocene palaeogeography of the Paratethys and its relation to the Mediterranean. Palaeogeography, Palaeoclimatology, Palaeoecology, 238(1-4), 91-106.

Ramdohr, K., 1808. Über die Gattung Cypris und drei zu derselben gehörige neue Arten. Magazine Gesellschaft Naturforschender Freunde zu Berlin für die Neuesten Entdeckungen in der Gesammten Naturkunde, 2, 85-93.

Rausch, L. and Stoica, M., 2019. An early Pleistocene anomalohaline water ostracod fauna from lake deposits of the Homo erectus-bearing Kocabaş locality (SW Turkey). Acta Palaeontologica Romaniae, 15(2), p. 40-68.

Rögl, F., 1998. Palaeogeographic considerations for Mediterranean and Paratethys seaways (Oligocene to Miocene). Annalen des Naturhistorischen Museums in Wien. Serie A für Mineralogie und Petrographie, Geologie und Paläontologie, Anthropologie und Prähistorie, 99, 279-310.

Sands, A. F., Sereda, S. V., Stelbrink, B., Neubauer, T. A., Lazarev, S., Wilke, T. and Albrecht, C., 2019. Contributions of biogeographical functions to species accumulation may change over time in refugial regions. Journal of Biogeography, 46(6), 1274-1286.

Sakınç, M. and Yaltırak, C., 2005. Messinian crisis: What happened around the northeastern Aegean? Marine geology, 221(1-4), 423-436.

Saraç, G., 2003. The vertebrate fossil localities of Turkey. Scientific Report, (10609), 1-208.

Sars, G. O., 1887. Nye bidrag til kundskaben om middelhavets invertebratfauna: 4. Ostracoda Mediterranea (Sydeuropaeiske Ostracoder). Archiv for Mathematik og Naturvidenskab, 12, 173-324.

Sars, G. O., 1890. An account of the Crustacea of Norway with short descriptions and figures of all the species, 711 pp. Christiania: Cammermeyers, 1895.

Sars, G. O., 1925. An account of the Crustacea of Norway. Cytheridae, Christiania: Cammermeyers, 1- 177, pls-81.

Schweyer, A. V., 1949. On the Pliocene Ostracoda of the Northern Caucases and Lower Volga Region. With some new data on the systematics of fossil ostracods. Trudy Vesoyuznogo Neftyanogo NauchnoIsseldovatelskogo Geologo-Razvedochnogo Instituta (VNIGRI), 30, 9-68. 
Seyitoğlu, G., Işık, V. and Cemen, I., 2004. Complete Tertiary exhumation history of the Menderes massif, western Turkey: an alternative working hypothesis. Terra Nova, 16(6), 358-364.

Sickenberg, O., Tobien, H., 1971. New Neogene and Lower Quaternary vertebrate faunas in Turkey. Newsletter on Stratigraphy 1 (3), 51-61.

Sissingh, W., 1974. Miocene ostracoda from Hipparionbearing beds of Kastellios-Hill, Central Crete. Proceedings of the Koninklijke Nederlandse Akademie van Wetenschappen Series B-Palaeontology Geology Physics Chemistry Anthropology, 77 (2), 119-128.

Sokač, A., 1967. Pannonische und Pontische Ostracoden fauna des südwestlichen Teiles des Pannonischen Becken. In Carpatho-Balkan Geological Association, 8th Congress, Belgrade, Rep. Stratigrafia.

Sokač, A., 1972. Pannonian and Pontian Ostracode fauna of Mt. Medvednica: Panonska i pontska fauna ostrakoda Medvednice (Vol. 11). Palaeontologia Jugoslavica, 11: 1-140, Zagreb.

Sokač, A., 1990. The Pontian in Croatia. Chronostratigraphie und Neostratotypen: Neogen der Westlichen ("Zentrale") Paratethys, In: Malez, M. and Stevanović, P. (Eds.): Chronostratigraphie und Neostratotypen, Neogen der Westlichen (,Zentralen”) Paratethys. Pontien. - 8 (Pl1): , Verlag der Jugoslawischen Akademie der Wissenschaften und Künste und der Serbischen Akademie der Wissenschaften und Künste, Zagreb/Belgrad 8, 180194.

Spadi, M., Gliozzi, E. and Medici, M. C., 2018. A PlioPleistocene Caspiocypris species flock (Candoninae, Ostracoda) from the Palaeolake Tiberino (Umbria, central Italy). Journal of Systematic Palaeontology, 16(5), 417-434.

Spadi, M., Gliozzi, E. and Medici, M. C., 2019. Piacenzian-Gelasian non-marine ostracods from the Dunarobba Fossil Forest (Tiberino Basin, Umbria, central Italy). Papers in Palaeontology, 5(3), 391-413.

Stancheva, M., 1964. Ostracoda from the Neogene in north-western Bulgaria. III. Maeotian Ostracoda. Bulgarian Academic Nauk, Geological Institute, Series Palaeontology, 6, 83-84.

Stancheva, M., 1968. New data on the subfamily Leptocytherinae Hanai, 1957. Bulgarian Academy of Sciences, Sofia, Bulletin of the Geological Institute, 17, 37-48.

Stancheva, M., 1989. Taxonomy and biostratigraphy of the Pleistocene ostracods of the Western Black Sea Shelf. Geologica Balcanica, 19(6), 3-39.

Stancheva, M. A., 1990. Upper Miocene ostracods from northern Bulgaria. Geologica Balcanica, 5, Bulgarian Academy of Science, 1-116.

Stevanović, P. M., Nevesskaya, L. A., Marinescu, F., Sokać, A., Jámbor, Á. (Eds.), 1989. Chronostratigraphie und Neostratotypen, Neogen der Westlichen ("Zentrale") Paratethys VIII, P11, Pontien. Jazu and Sanu, Zagreb-Beograd, pp. 1-952.

Stoica, M., Lazăr, I., Krijgsman, W., Vasiliev, I., Jipa, D. and Floroiu, A., 2013. Paleoenvironmental evolution of the East Carpathian foredeep during the late Miocene-early Pliocene (Dacian Basin; Romania). Global and Planetary Change, 103, 135-148.
Stoica, M., Krijgsman, W., Fortuin, A. and Gliozzi, E., 2016. Paratethyan ostracods in the Spanish LagoMare: More evidence for interbasinal exchange at high Mediterranean sea level. Palaeogeography, Palaeoclimatology, Palaeoecology, 441, 854-870.

Sun, S., 1990. Denizli Uşak arasının jeolojisi ve linyit olanakları . Mineral Res. Expl. Direct. Turkey (MTA), Scientific Report No: 9985, Ankara, Turkey (in Turkish) pp. 92.

Suzin, A. V., 1956. Ostracoda from Tertiary deposits of the North Caucasus. Gostoptekhizdat, Moscow, 1191.

Symposium on the Classification of Brackish Waters, 1958. The Venice system for the classification of marine waters according to salinity. Oikos, 9, 311-312.

Şafak, Ü., 2010. Environmental Properties and Ostracoda Group of Tertiary Sequences of Güney-BuldanYenicekent-Babadağ-Kale Area (Denizli, SW Anatolia). Kahramanmaraş Sütçü İmam Üniversitesi Mühendislik Bilimleri Dergisi (in turkish), 13(2), 4462.

Şimşek, Ş., 1984. Denizli-Kızıldere-TekkehamamTosunlar-Buldan-Yenice alanının jeolojisi ve jeotermal enerji olanaklar1. Mineral Resources and Exploration Direct. Turkey (MTA), Scientific Report, (7846), 1-85.

Taner, G., 1974a. Denizli bölgesi Neojen'inin paleontolojik ve stratigrafik etüdü. Bulletin of the Mineral Research and Exploration, Turkey (MTA) 82, 89-126.

Taner, G., 1974b. Denizli bölgesi Neojen'inin paleontolojik ve stratigrafik etüdü. Bulletin of the Mineral Research and Exploration, Turkey (MTA) 83, 145177.

Taner, G., 1975. Denizli bölgesi Neojen'inin paleontolojik ve stratigrafik etüdü. Bulletin of the Mineral Research and Exploration, Turkey (MTA) 85, 45-66.

Taner, G., 2001. Denizli bölgesi Neojen'ine ait katların stratigrafik konumlarında yeni düzenleme. 54. Jeoloji Kurultay1, Bildiri Cd, 54-79.

Ter Borgh, M., Vasiliev, I., Stoica, M., Knežević, S., Matenco, L., Krijgsman, W., Rundić, L., Cloetingh, S., 2013. The isolation of the Pannonian basin (Central Paratethys): New constraints from magnetostratigraphy and biostratigraphy. Global and Planetary Change, 103, 99-118.

Ter Borgh, M., Stoica, M., Donselaar, M. E., Matenco, L. and Krijgsman, W., 2014. Miocene connectivity between the Central and Eastern Paratethys: Constraints from the western Dacian Basin. Palaeogeography, Palaeoclimatology, Palaeoecology, 412, 45-67.

Tunoğlu, C., 2001. Ponsiyen yaşlı yeni Tyrrhenocythere türleri (Arakl1/Trabzon), Doğu Karadeniz Bölgesi, Türkiye. Yerbilimleri Dergisi, 22(23), 129-143.

Tunoğlu, C., 2003. Systematics and biostratigraphy of the Pontian Candonidae (Ostracoda) from the Eastern Black Sea Region (Northern Turkey). Geologica Carparthica-Brastislava, 54(1), 21-40.

Tunoğlu, C. and Çelik, M., 1995. The ostracoda association and environmental characteristics of Lower Miocene sequence of Ilgin (Konya) district, Central Anatolia, Turkey. In Ostracoda and Biostratigraphy: Pro- 
ceedings of the 12th International Symposium on Ostracoda, Prague (pp. 229-235).

Tunoğlu, C. and Ünal, A., 2001. Pannonian-Pontian Ostracoda fauna of Gelibolu Neogene Basin (NW Turkey). Yerbilimleri, 23, 167-187.

Van Baak, C. G., Vasiliev, I., Stoica, M., Kuiper, K. F., Forte, A. M., Aliyeva, E. and Krijgsman, W., 2013. A magnetostratigraphic time frame for Plio-Pleistocene transgressions in the South Caspian Basin, Azerbaijan. Global and Planetary Change, 103, 119-134.

Van Baak, C. G., Mandic, O., Lazar, I., Stoica, M. and Krijgsman, W., 2015. The Slanicul de Buzau section, a unit stratotype for the Romanian stage of the Dacian Basin (Plio-Pleistocene, Eastern Paratethys). Palaeogeography, palaeoclimatology, palaeoecology, 440, 594-613.

Van Baak, C. G., Stoica, M., Grothe, A., Aliyeva, E. and Krijgsman, W., 2016. Mediterranean-Paratethys connectivity during the Messinian salinity crisis: The Pontian of Azerbaijan. Global and Planetary Change, 141, 63-81.

Van Morkhoven, F. P., 1962. Post-palaeozoic ostracoda: their morphology, taxonomy, and economic use. 1. General. Elsevier, 1-204.

Vávra, W., 1891. Monographie der Ostracoden Böhmens (Vol. 3). Archiv der naturwissenschaftlichen landesdurchforschung von Böhmen, 8 (3), 1-116..

Vekua, M. L., 1975. The ostracods of the Kimmerian and Kujalinikian deposits of Abkhazia and their stratigraphic significance. Academia Nauc Gruzinskoi, SSR Ed. Metzniereba, Tibilisi, 1-137.

Velde, S.V.D. and Jorissen, E. L., Neubauer, T. A., van Baak, C., Abels, H., Radan, S., Krijgsman, W. and Wesselingh, F.P., 2019. Integrating sedimentological and palaeontological analysis for conservation strategies: the Razim-Sinoie lake complex (Danube Delta, Romania) as a model example. In EGU General Assembly Conference Abstracts (Vol. 20, p. 12688).

Viehberg, F. A., 2005. Quantitative paleoenvironmental studies using freshwater ostracods in northeast Germany. Ph.D. dissertation, Ernst-Moritz-ArndtUniversität Greifswald, Germany, 1-135.

Wagner, C. W., 1964. Ostracods as environmental indicators in Recent and Holocene estuarine deposits of The
Netherlands. Pubblicazioni della Stazione zoologica di Napoli, 33(suppl.), 480-495.

Wesselingh, F.P., 2007. Long-lived lake molluscs as island faunas: a bivalve perspective. In: Renema W. (Ed.) Biogeography, time, and place: distributions, barriers, and islands (pp. 275-314). Springer, Dordrecht.

Wesselingh, F.P., Alçiçek, H., Magyar, I., 2008. A Late Miocene Paratethyan mollusc fauna from the Denizli Basin (southwestern Anatolia, Turkey) and its regional palaeobiogeographic implications. Geobios 41, 861-879.

Whatley, R. C., 1988. Ostracoda and palaeogeography. In: de DeckkerP., Colin J.-P and Peypouquet J.-P. (Eds.) .Ostracoda in the Earth Sciences, 103-123.

Yalçınlar, İ., 1983. Türkiye'de neojen ve kuaterner omurgalı araziler ve jeomorfolojik karekterleri. İstanbul Üniversitesi Edebiyat Fakültesi Yayınları, No. 2741, 1-239.

Yanina, T. A., 2012. Correlation of the Late Pleistocene paleogeographical events of the Caspian Sea and Russian Plain. Quaternary International, 271, 120-129.

Yassini, I., 1986. Ecology, paleoecology and stratigraphy of ostracodes from Upper Pliocene and Quaternary deposits of the South Caspian Sea, North Iran. Lake Illawarra Management Committee, 1-78.

Yassini, I., 1987. Ecology, paeloecology and stratigraphy of ostracodes from Late Pliocene and Quaternary deposits of the south Caspian Sea region in north Iran. In International symposium on Shallow Tethys 2, 475-497.

Yassini, I. and Ghahreman, A., 1976. Récapitulation de la distribution des ostracodes et des foraminifères du lagon de Pahlavi, province de Gilan, Iran du nord. Revue de Micropaléontologie, 19(3), 172-190.

Zalányi, B., 1929. Morpho-systematische Studien über fossile Muschelkrebse., Geol. Hung., Ser. Paleontol. $5,1-152$. 